Учредители: Национальная академия наук Украины, Институт электросварки им. Е. О. Патона НАН Украины, Международная ассоциация «Сварка» (издатель)

РЕДАКЦИОННАЯ КОЛЛЕГИЯ

Главный редактор

Б. Е. ПАТОН

О. И. Бойчук, Э. Ф. Гарф,

Е. А. Давыдов, А. Т. Зельниченко,

Л. М. Лобанов, 3. А. Майдан (отв. секр.),

А. Я. Недосека (зам. гл. ред.), Ю. Н. Посыпайко,

В. А. Троицкий (зам. гл. ред.), Е. В. Шаповалов

ИЭС им. Е. О. Патона, Киев, Украина

\section{В. А. Стрыжало}

Ин-т проблем прочности, Киев, Украина

Н. П. Алешин

МГТУ им. Н. Э. Баумана, Москва, РФ

В. Л. Венгринович

Ин-т техн. физики, Минск, Республика Беларусь

М. Л. Казакевич

Ин-т физической химии, Киев, Украина

О. М. Карпаш

Ив.-Франк. нац. техн. ун-т нефти и газа, Украина В. В. Клюев

ЗАО НИИИН МНПО «Спектр», Москва, РФ

3. Т. Назарчук, В. Н. Учанин

Физ.-мех. ин-т, Львов, Украина Н. В. Новиков

Ин-т сверхтвердых материалов, Киев, Украина Г. И. Прокопенко

Ин-т металлофизики, Киев, Украина

В. А. Стороженко

Харьков. нац. ун-т радиоэлектроники, Украина С. К. Фомичов

Нац. техн. ун-т Украины «КПИ», Киев М. Г. Чаусов

Нац. ун-т биорес. и природопольз. Украины, Киев В. Е. Щербинин

ИФМ УрО РАН, Екатеринбург, РФ

\section{Адрес редакции}

03680, Украина, г. Киев-150, ул.Боженко, 11

ИЭС им. Е.О.Патона НАН Украины

Тел./Факс: (044) 200-82-77, 205-23-90

E-mail: journal@paton.kiev.ua

www.patonpublishinghouse.com

Научные редакторы

Е. А. Давыдов, Л. Ф. Харченко

Редакторы

Л. Н. Герасименко, Д. И. Середа, Т. В. Юштина

Свидетельство

о государственной регистрации

КВ4787 от 09.01.2001.

Журнал входит в перечень

утвержденных МОН Украины

изданий для публикации трудов

соискателей ученых степеней

\section{СОДЕРЖАНИЕ}

ЭФФЕКТИВНЫЙ КОНТРОЛЬ. Акустико-эмиссионныЙ мониторинг - современная технология обеспечения безопасной эксплуатации энергетического оборудования 3

\section{НАУЧНО-ТЕХНИЧЕСКИЙ РАЗДЕЛ}

ЛОБАНОВ Л.М., ЗНОВА В.А., ПИВТОРАК В.А., КИЯНЕЦ И.В.

Контроль коррозионных повреждений элементов и узлов авиационных конструкций методом электронной ширографии

НЕДОСЕКА А.Я., НЕДОСЕКА С.А. Моделирование колебаний чувствительной пластинки применительно к датчикам акустической эмиссии. Сообщение 2 .

НЕКЛЮДОВ І.М., НАЗАРЧУК З.Т., СКАЛЬСЬКИЙ В.Р.,

ДОБРОВОЛЬСЬКА Л.Н. Застосування методу акустичної

емісії для діагностування корпусів ядерних реакторів (Огляд).

Повідомлення III. Нормативна база і перспективи застосування методу акустичної емісії в ядерній енергетиці....

МАЄВСЬКИЙ С.М. Прецизійне вимірювання швидкості ульт-

развукових коливань як метод оцінки напружень та утоми

конструкційних матеріалів ...................................................... 26

МЕШКОВ С.Н., ОРЕЛ Р.П. Применение термографии для определения состояния металла трубопроводов ..................................... 30 ЮХИМЕЦ П.С., КОБЕЛЬСКИЙ С.В., ФИЛИПЕНКОВ В.В. ЦИКЛИческая прочность поврежденного тройникового соединения .

ПАВЛОВСЬКИЙ О.М. Перевірка працездатності та ефрективності багаторівневої системи контролю вібрації авіаційних двигунів ... 39 ГЛУХОВСЬКИЙ В.Ю. Визначення тепловізійним методом контролю геометричних параметрів дефектів потенційно небезпечних важкодоступних об'єктів

\section{ПРОИЗВОДСТВЕННЫЙ РАЗДЕЛ}

БУРАУ Н.И., КУЛИШ Э.В. Оценка параметра изменения функционального технического состояния противооползневого анкерного сооружения по результатам вибрационной диагностики .... 49 ЗАВАЛЬНЮК И.П. Контроль герметичности закупоренных консервных банок при переработке сельскохозяйственной продукции

\section{СЕРТИФИКАЦИЯ И СТАНДАРТИЗАЦИЯ}

ТРОИЦКИЙ В.А., ПОСЫПАЙКО Ю.Н., ЩУПАК С.А.

Евроинтеграция и состояние стандартизации в области

неразрушающего контроля в Украине.

\section{ХРОНИКА И ИНФОРМАЦИЯ}

IX Всеукраинский фестиваль науки ................................................. 61

Конференция-выставка «Неразрушающий контроль 2015»

ИЗДАНИЕ ПОДДЕРЖИВАЮТ:

Технический комитет по стандартизации «Техническая диагностика и неразрушающий контроль» ТК-78

Украинское общество неразрушающего контроля и технической диагностики 
Founders: The National Academy of Sciences of Ukraine, The E. O. Paton Electric Welding Institute NASU, International Association «Welding» (Publisher)

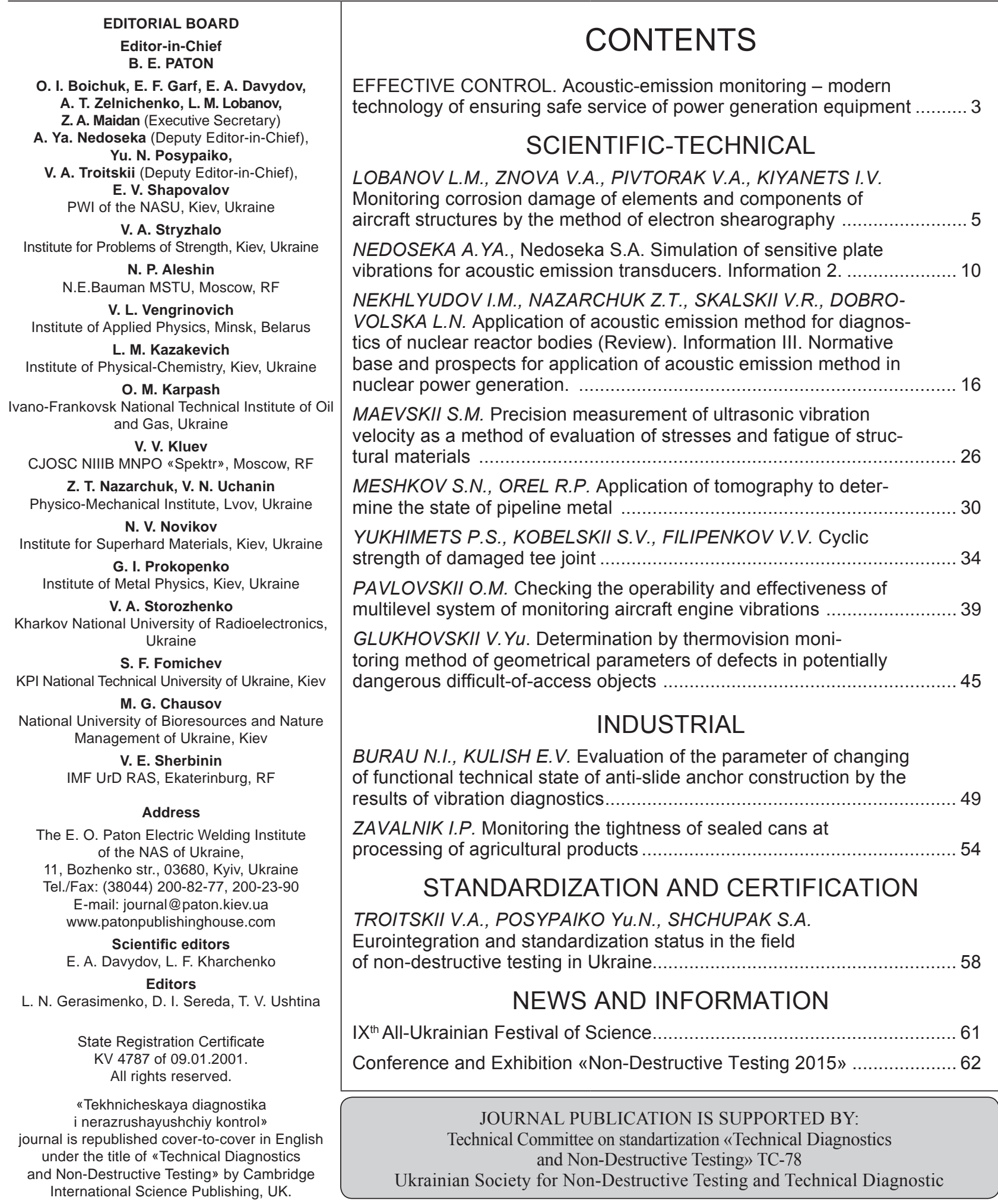




\title{
ЭФФЕКТИВНЫЙ КОНТРОЛЬ
}

\author{
Акустико-эмиссионный мониторинг - \\ современная технология обеспечения безопасной \\ эксплуатации энергетического оборудования*
}

\begin{abstract}
Энергетика - стратегически важная отрасль промышленности Украины, однако большая часть существующих объектов энергетики построена еще в УССР, и в настоящее время нуждается в серьезной модернизации. Одна из приоритетных научно-технических задач в отрасли - продление ресурса оборудования и вывод его из эксплуатации по фактическому состоянию. Эффрективным средством решения этой задачи является создание инфрормационно-измерительных систем непрерывного мониторинга, позволяющих контролировать работоспособность оборудования непосредственно в процессе эксплуатации с оценкой его фрактического состояния. Современное развитие средств вычислительной техники, радиоэлектроники, прикладной математики, техники испытаний, науки о прочности материалов и механики сплошной среды позволяет решить эту задачу на достаточно высоком уровне.
\end{abstract}

$\Pi^{p}$ римером успешного сотрудничества науки и производства является разработка и внедрение систем непрерывного мониторинга на тепловых станциях СОП «Киевские ТЭЦ» одним из наиболее авторитетных научных институтов НАН Украины - Институтом электросварки им. Е.О. Патона. Учитывая важность направления технической диагностики, его на протяжении многих лет возглавляет академик Б.Е. Патон.

В основе работы автоматизированных систем мониторинга «ЕМА» лежит новая эффективная технология оценки работоспособности металлоконструкций, базирующаяся на анализе данных акустической эмиссии (АЭ) и технологических параметров состояния конструкций (давления, температуры и т.п.), получаемых в процессе эксплуатации без изменения их режимов. Технология позволяет осуществлять 100\%-ный контроль конструкций или их узлов без разрушения, заблаговременно спрогнозировать разрушающую нагрузку (фрактически, определить предел прочности при текущем состоянии), оценить остаточный ресурс материала конструкции. Созданные системы мониторинга работают полностью автономно, без участия оператора, и обеспечивают предупреждение о возможной опасности при помощи цветовой и звуковой индикации.
Следует отметить, что системы непрерывного мониторинга, разработанные в ИЭС им. Е.О. Патона, уже получили достаточно широкое распространение: с 2002 г. используются для контроля состояния сосудов давления, хранилищ и оборудования цехов производства аммиака Одесского припортового завода, с 2004 г. - на мостовых переходах труб аммиакопровода Тольятти-Одесса («Укрхимтрансаммиак»).

Научно-техническое сотрудничество СОП «Киевские ТЭЦ» с ИЭС им. Е.О. Патона по реализации научных разработок и опыта института началось в 2006 г., когда решением руководства «Киевэнерго» и ИЭС была утверждена «Программа работ по внедрению технологии непрерывного АЭ мониторинга на оборудовании ТЭЦ «Киевэнерго».

Первым этапом работ стало проведение предварительных исследований по оценке состояния узлов, агрегатов и трубопроводов киевских ТЭЦ-5 и ТЭЦ-6 с последующим выбором объектов, подлежащих непрерывному АЭ-мониторингу в первую очередь. Учитывая, что существенная часть оборудования ТЭЦ работает в условиях высоких температур, ИЭС разработал специальный стенд и провел высокотемпературные АЭ-испытания об-

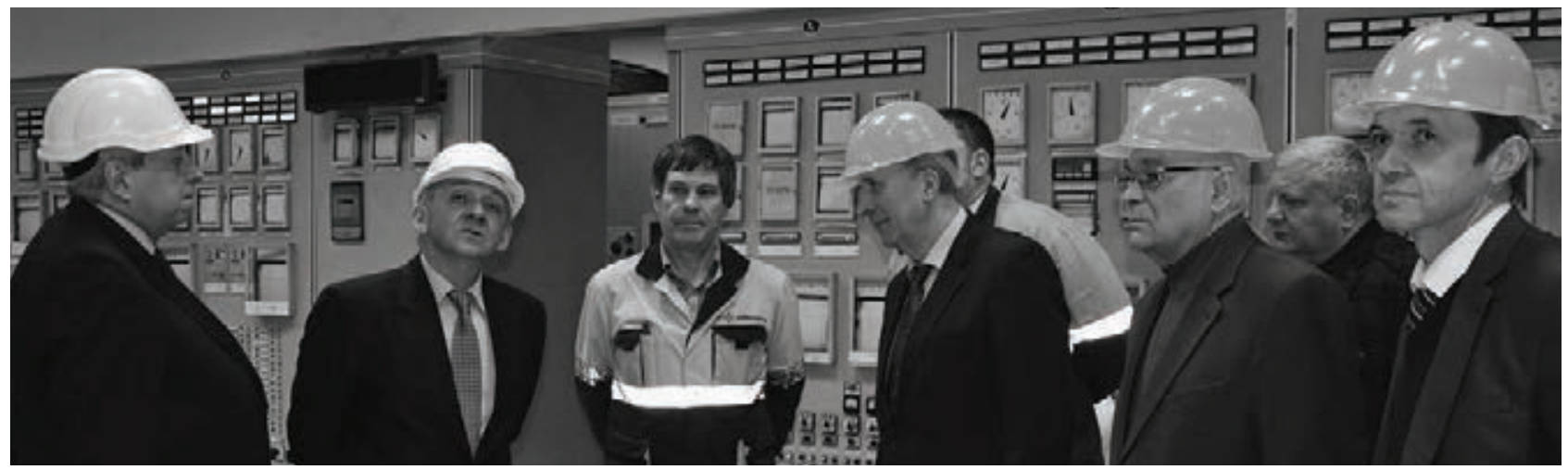

* По материалам статьи, опубликованной в журнале «Энергобизнес» №50/888 
разцов из материалов, наиболее широко применяемых на ТЭЦ. Этап, учитывая большой объем работ и новизну исследований, занял несколько лет и завершился положительными результатами. Метод АЭ показал высокую эффективность при поиске дефектов и оценке состояния материала в процессе кратковременных испытаний целого ряда объектов ТЭЦ, включая трубопроводы различного назначения и барабаны котлов. Термоиспытания образцов подтвердили, что метод АЭ сохраняет достаточно высокую информативность в диапазонах высоких температур, характерных для объектов теплоэнергетики, и позволяет заблаговременно спрогнозировать разрушение материала. По итогам первого этапа были сформулированы технические требования к системе мониторинга применительно к условиям ТЭЦ, составлено и утверждено техническое задание на разработку и внедрение системы.

Второй этап работ включал разработку, изготовление и монтаж опытного образца системы непрерывного АЭ-мониторинга. В качестве первоочередного объекта мониторинга были выбраны трубопроводы горячего промперегрева блока №1 ТЭЦ-6. Работы по монтажу оборудования начаты в 2010 г. параллельно с проведением АЭ-исследований на объекте контроля в процессе его эксплуатации. В соответствии с техническими требованиями и представленными в техническом задании схемами, выполнены монтаж системы непрерывного мониторинга, ее подключение к энергоснабжению и компьютерной сети предприятия.

Этап завершился комплексной проверкой системы, включая соответствие заявленным эксплуатационным параметрам и длительности автономной работы при мониторинге трубопровода в его рабочем состоянии. По итогам второго этапа были сделаны выводы о возможности начала опытной эксплуатации системы непрерывного мониторин- га с последующим переходом к штатному режиму работы. Учитывая положительные результаты этапа, было принято решение о непрерывном мониторинге барабана котла ТГМ-6 на ТЭЦ-5.

Обучение специалистов ТЭЦ-5 и ТЭЦ-6 позволило предприятиям самостоятельно начать эксплуатировать поставленное оборудование.

В 2014 г. выполнены этапы 1 и 2 по созданию системы непрерывного мониторинга барабана котла ТГМ-6 на Киевской ТЭЦ-5. Начат третий этап работ, система запущена в режим опытной эксплуатации.

В ноябре 2014 г. состоялось обсуждение достигнутых результатов и подведение итогов сотрудничества СОП «Киевские ТЭЦ» с ИЭС им. Е.О. Патона. В обсуждении приняли участие руководство и технические специалисты, в том числе со стороны ПАО «Киевэнерго» - директор Ю.И. Гладышев, гл. инженер В.М. Бешун, гл. инженер ТЭЦ-6 А.В. Бычков, со стороны ИЭС им. Е.О. Патона - зам. директора, академик НАНУ Л.М. Лобанов, зав. отделом технической диагностики сварных конструкций проф. А.Я. Недосека, с.н.с. М.А. Яременко.

В процессе обсуждения были отмечены научная новизна и эффрективность внедряемых методов обеспечения безопасности эксплуатации энергооборудования. Подтверждено, что внедрение СОП «Киевские ТЭЦ» передовых научных разработок уже дает конкретные результаты в виде повышения безопасности эксплуатации объектов непрерывного АЭ-мониторинга. Со стороны «Киевэнерго» высказано стремление к дальнейшему сотрудничеству и распространению разработанной технологии на следующие ответственные объекты ТЭЦ-5 и ТЭЦ-6, а также на другие ТЭЦ. Академиком НАНУ Л.М. Лобановым отмечена важность широкого внедрения разработанной технологии на самых различных предприятиях отрасли, в том числе в атомной энергетике.

\section{Комментарий}

Говоря о необходимости внедрения и использования акустико-эмиссионного мониторинга, директор СОП «Киевские ТЭЦ» Юрий Гладышев отметил актуальность технической диагностики оборудования, обеспечивающего бесперебойную работу мощностей предприятия, в частности оборудования, отработавшего заложенный в него ресурс. В этом случае АЭ-мониторинг позволяет оперативно оценить состояние оборудования и продлить срок его службы.

«Основной задачей АЭ-мониторинга является уход от «человеческого фактора». Используемая система - это комплект датчиков, информация с которых поступает на единый контрольный комплекс. Система автоматически отслеживает ситуацию и выдает информацию о состоянии оборудования. На основании этих данных мы не только получаем подробную информацию о текущей ситуации, но и можем спрогнозировать необходимые работы. Фактически, АЭ-мониторинг позволяет получить полную картину состояния объекта», - объяснил он.

Комментируя экономические аспекты внедрения системы АЭ-мониторинга, Ю.Гладышев отметил, что ранее запущенные аналогичные проекты позволили достичь на предприятии экономического эфрректа с показателями до 100\%. Однако в данном случае прогнозировать экономический эффрект от реализуемого на ТЭЦ-6 пилотного проекта затруднительно из-за уникальности поставленных задач, поскольку этот пилотный проект не имеет аналогов на территории Украины. 


\title{
КОНТРОЛЬ КОРРОЗИОННЫХ ПОВРЕЖДЕНИЙ ЭЛЕМЕНТОВ И УЗЛОВ АВИАЦИОННЫХ КОНСТРУКЦИЙ МЕТОДОМ ЭЛЕКТРОННОЙ ШИРОГРАФИИ
}

\author{
Л.М. ЛОБАНОВ ${ }^{1}$, В.А. ЗНОВА ${ }^{2}$, В.А. ПИВТОРАК ${ }^{1}$, И.В. КИЯНЕЦ ${ }^{1}$ \\ ${ }^{1}$ ИЭС им. Е. О. Патона НАНУ. 03680, г. Киев-150, ул. Боженко, 11. E-mail: office@paton.kiev.ua \\ ${ }^{2} Г П$ «Антонов». 03062, г. Киев, ул. Акад. Туполева, 1. E-mail: info@antonov.com
}

\begin{abstract}
Разработана технология контроля коррозионных повреждений в виде утонения и трещин в элементах авиационных конструкций методом электронной ширографии, который позволяет выявлять концентрацию напряжений, обусловленную присутствием дефекта или конструктивными особенностями исследуемого объекта. Эффективность использования метода ширографии для выявления коррозионных повреждений различных типов, размеров и формы показана в экспериментах как на тестовых образцах, так и на натурных элементах обшивки фюзеляжа и крыла самолета без демонтажа внутренней облицовки и герметика. Библиогр. 8 , рис. 4.
\end{abstract}

Ключев ви е слов а: неразрушающий контроль качества, диагностика авиачионных конструкций, ширография, коррозия

В современных отраслях авиационной промышленности одной из актуальных задач является обеспечение качества и работоспособности элементов и узлов конструкций, которые работают в условиях сложного механического воздействия и температурных градиентов. В летательных аппаратах применяются различные металлические материалы: стали, сплавы алюминия, титана, меди и др. Во многих узлах и агрегатах летательных аппаратов металлические детали контактируют одна с другой и с разнородными жидкостями и газообразными средами, что может привести к коррозионным повреждениям.

Коррозия - один из наиболее опасных видов разрушений металлических элементов авиационных конструкций (летательных аппаратов), поскольку процессы разрушения могут протекать скрытно, например, под накладками или внутри многослойных конструкций. Это приводит к недопустимому уменьшению прочности, а значит и к снижению уровня надежности авиационных конструкций [1-3]. В связи с этим большое внимание уделяется анализу коррозионного состояния конструкций, изучению количественных и качественных закономерностей развития коррозионных процессов в различных условиях эксплуатации и оценке влияния коррозионных повреждений на работоспособность, технико-экономические показатели конструкции. Также актуальным остается развитие методов и средств технической диагностики и прогнозирование ресурса авиационных конструкций [3-5].

В настоящее время для решения задач неразрушающего контроля (НК) применяются различные методы: рентгеновский, ультразвуковой, акустической эмиссии, вихревых токов и др. $[1,3,4]$.
Однако в ряде случаев разрешающая способность этих методов недостаточна, кроме того они не позволяют получать информацию одновременно по большим участкам исследуемых объектов.

Перспективным представляется применение для этих целей методов лазерной интерферометрии, отличающихся высокой чувствительностью к поверхностным перемещениям и деформациям, имеющих ряд преимуществ: возможность визуального наблюдения в реальном времени картины интерференционных полос, характеризующей деформацию поверхности; бесконтактностью; возможность применения для исследования объектов сложной формы; отсутствие специальных требований к подготовке исследуемой поверхности [6].

Наиболее эффективным из них является метод электронной ширографии, который может использоваться при исследовании различных материалов и конструкций [6]. Следует отметить, что применение на практике обычно используемых методов неразрушающего контроля чаще всего происходит в ненагруженных элементах и узлах конструкций. Электронная ширография, в противоположность этому, работает с нагруженными объектами и в отличие от традиционных методов контроля, которые только фиксируют наличие или отсутствие дефектов, она позволяет выявить концентрацию деформаций (напряжений), вызванную присутствием дефекта или конструктивными особенностями объекта. Интенсивное развитие этого метода в течение последнего десятилетия позволило ему войти в число достаточно широко применяемых методов контроля промышленной продукции [7].

При выполнении неразрушающего контроля качества (НКК) элементов и узлов конструкций ис- 
пользуется компактная ширографическая установка, состоящая из одномодового лазера для освещения поверхности исследуемого объекта, ширографического интерферометра, формирующего изображение объекта, CCD-камеры для записи и передачи изображения и компьютера для получения и обработки картин интерференционных полос [8].

При проведении экспериментов с помощью созданной технологии ширографического НКК исследовали элементы обшивки самолета размерами $600 \times 500 \times 1,5$ мм с заложенными с обратной стороны элемента дефектами в виде утонения диаметром 9 и 15 мм. Глубина внесенных дефектов не превышала 50 \% толщины элемента обшивки (рис. 1, $a$, рис. $2, a$ ).

НК элемента обшивки выполняли в такой последовательности: исследуемый участок образца освещали лазерным излучением и отраженную световую волну, которая характеризует начальное состояние контролируемой поверхности, записывали с помощью CCD-камеры в память компьютера. После этого контролируемый участок, с целью его деформирования, обдували нагретым воздухом $\left(\mathrm{T} \sim 100^{\circ} \mathrm{C}\right)$ в течение $2 . .5$ с и записывали в память компьютера отраженную световую волну, которая характеризует нагруженное состояние участка образца. При этом величина широсдвига составляла 5 мм вдоль направления оси ОХ или OY. С помощью специальной компьютерной программы записанную оптическую информацию обрабатывали до получения широграммы и распределения производной от перемещений нормальных к поверхности $\partial w / \partial \mathbf{x}$ или $\partial w / \partial y$ вдоль выбранного сечения.

На рис. 1 и 2 приведены результаты ширографического контроля качества элемента обшивки самолета. Локальное изменение величины и знака производных $\partial w / \partial x$ и $\partial w / \partial y$ вдоль исследуемых сечений $A-A$ и и $B-B$ характеризует наличие дефекта в контролируемом участке элемента обшивки.

Были выполнены исследования и эксперименты по контролю качества усиливающих элементов авиационных конструкций, изготовленных из сплава В95-Т, размерами $350 \times 30 \times 5$ мм с целью выявления коррозионных трещин. Исследуемый усиливающий элемент (рис. $3, a$ ) закреплялся в механическом нагрузочном устройстве, которое позволяло незначительно изогнуть его по нормали к поверхности, что приводило к большему раскрытию коррозионной трещины. После этого контролируемый участок освещали лазерным светом и отраженная световая волна, характеризующая начальное состояние поверхности усиливающего элемента, записывалась в память компьютера. Величина широсдвига составляла 5 мм вдоль направления оси $O Y$. Затем исследуемый участок поверхности обдувался потоком горячего воздуха с температурой $150^{\circ} \mathrm{C}$ в течение 20 с и в компьютер записывалась световая волна, характеризующая деформированное состояние контро-

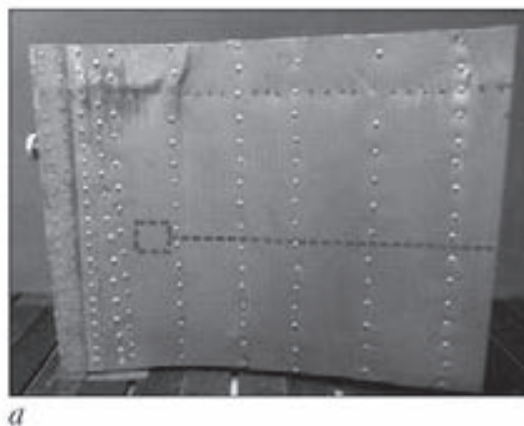

$a$

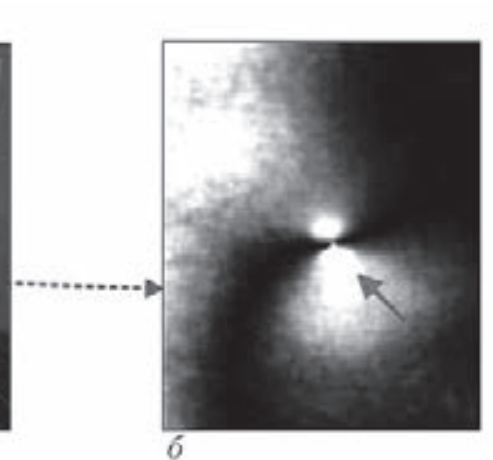

6

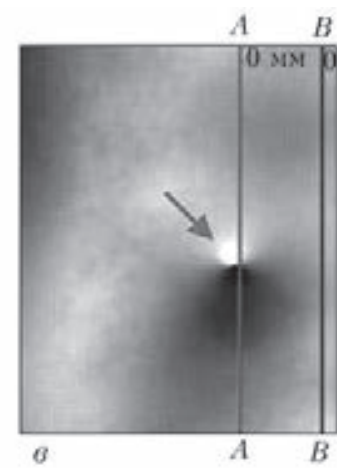

G

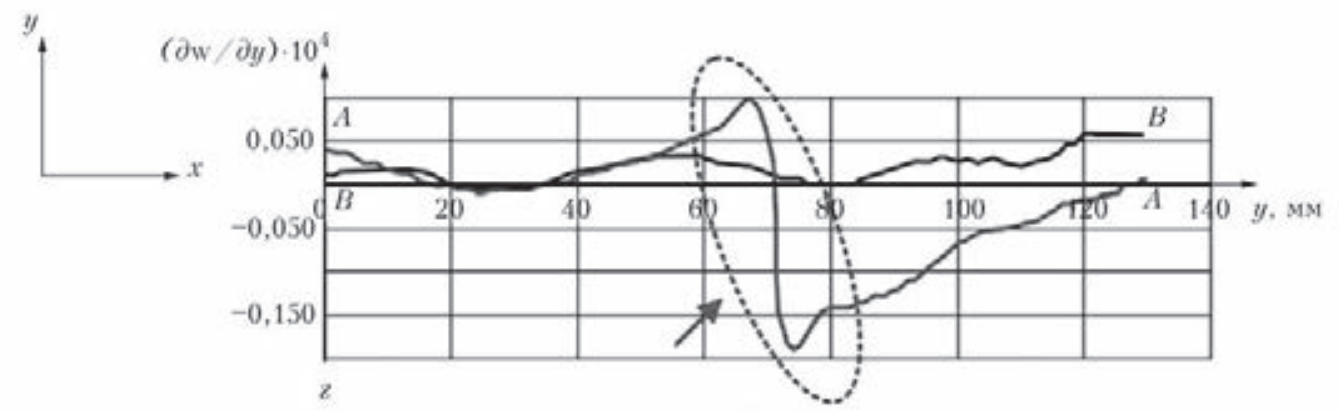

Puc. 1. Ширографический контроль элемента обшивки с внесенным дефектом (Ø 9 мм) с использованием в качестве нагружения обдува горячим воздухом (Т $100^{\circ} \mathrm{C}$ в течение 2 c) на стадии охлаждения: $a-$ общий вид элемента с выделенным участком контроля; $\sigma$ - интерференционная картина контролируемого участка; 8 - поверхность деформирования контролируемого участка с выбранными сечениями $A-A$ и $B-B ;$ - - кривые распределения производной $\partial w / \partial y$ вдоль выбранных сечений ( $B-B$ - сечение бездефектной зоны; $A-A$ - сечение с зоной дефекта, указаной стрелкой) 


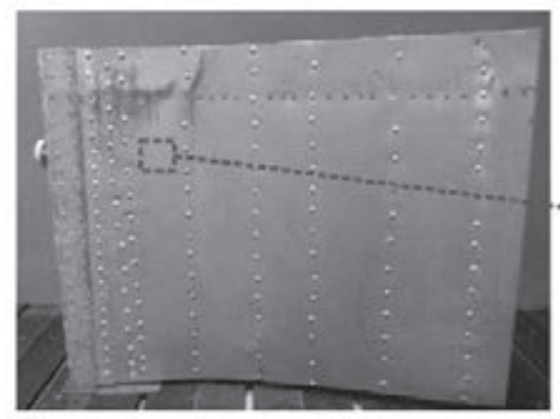

$a$

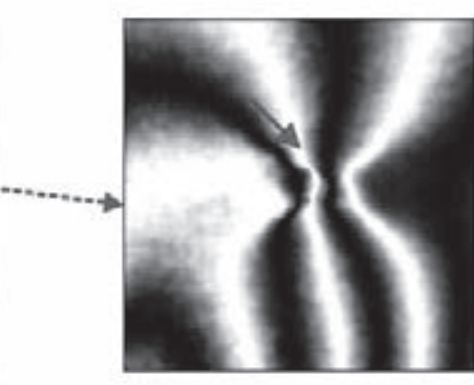

6

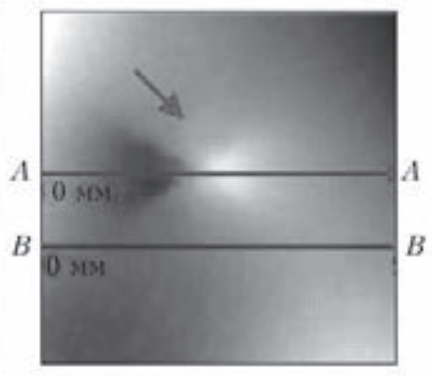

G

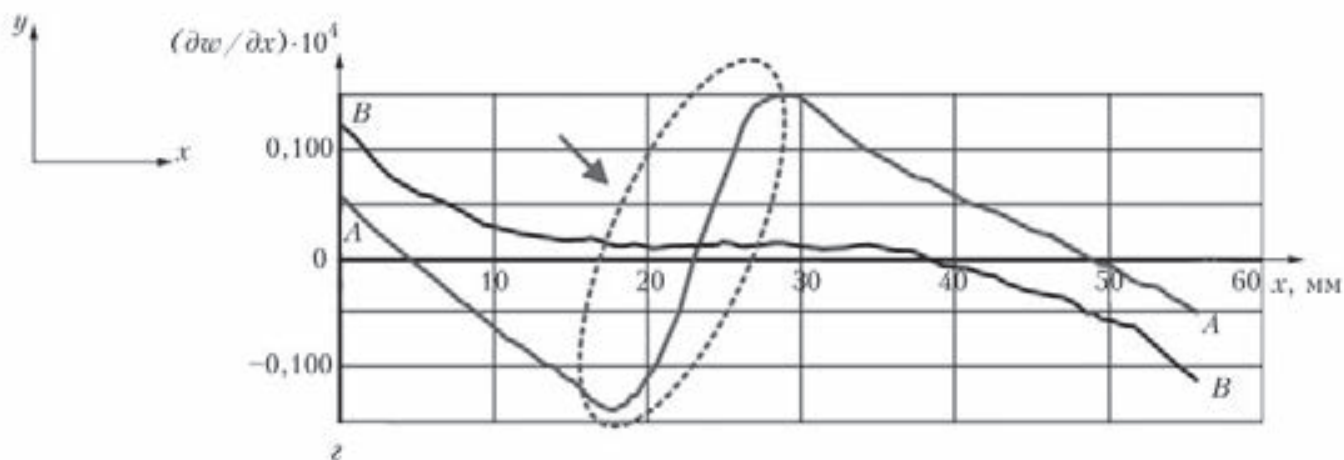

Puc. 2. Ширографический контроль элемента обшивки с внесенным дефектом (Ø 15 мм) с использованием в качестве нагружения обдува горячим воздухом (Т $100{ }^{\circ} \mathrm{C}$ в течение 5 c) на стадии нагрева: $a$ - общий вид элемента с выделенным участком контроля; $\sigma$ - интерференционная картина контролируемого участка; 6 - поверхность деформирования контролируемого участка с выбранными сечениями $A-A$ и $B-B ; 2-$ графики распределения производной $\partial w / \partial x$ вдоль выбранных сечений $(B-B$ - сечение бездефектной зоны; $A-A$ - сечение с зоной дефекта, указаной стрелкой)
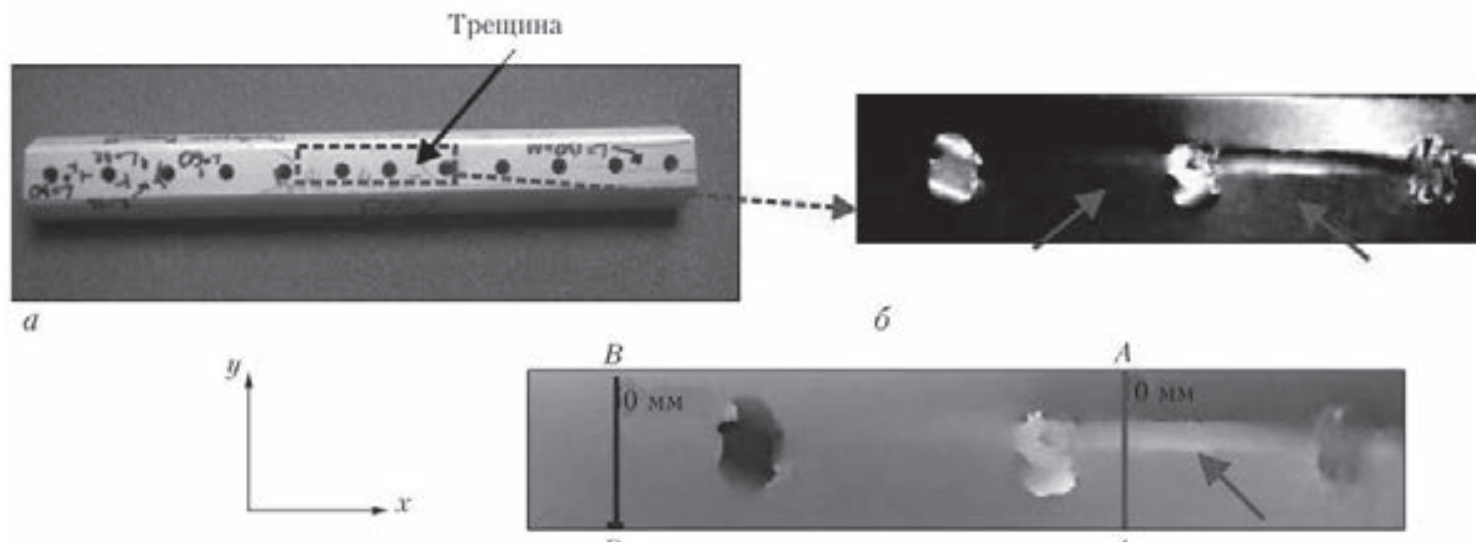

$(\partial w / \partial y) \cdot 10^{4}$

$B$

A

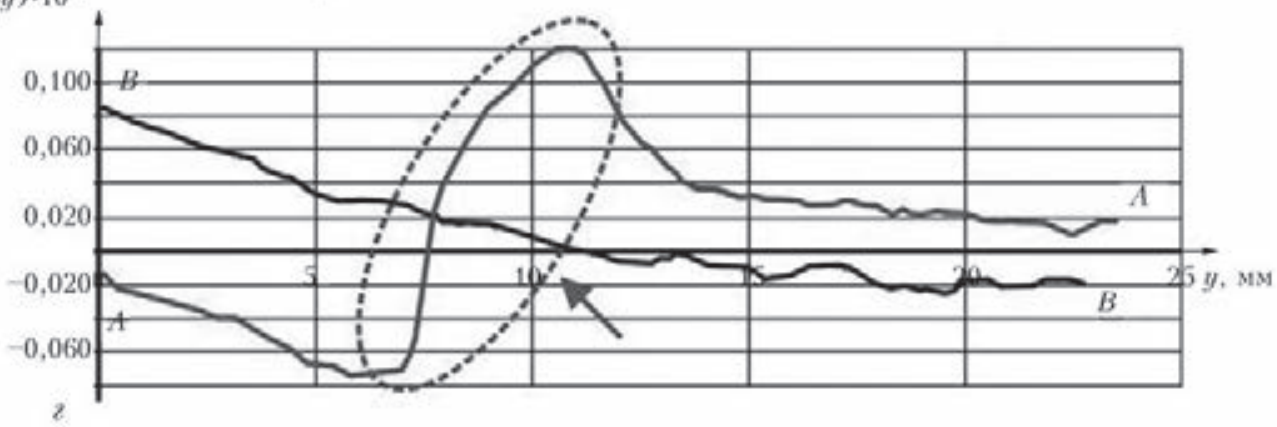

Puc. 3. Ширографический контроль усиливающего элемента авиационных конструкций с коррозионной трещиной с использованием в качестве нагружения обдува горячим воздухом $\left(T \sim 150^{\circ} \mathrm{C}\right.$ в течение 20 с) на стадии нагрева: $a$ - общий вид элемента с выделенным участком контроля; $\sigma$ - интерференционная картина контролируемого участка; 8 - поверхность деформирования контролируемого участка с выбранными сечениями $A-A$ и $B-B ;$ г - распределение производной $\partial w / \partial y$ вдоль выбранных сечений ( $B-B-$ сечение бездефектной зоны; $A-A-$ сечение с зоной дефекта, указаной стрелкой) 

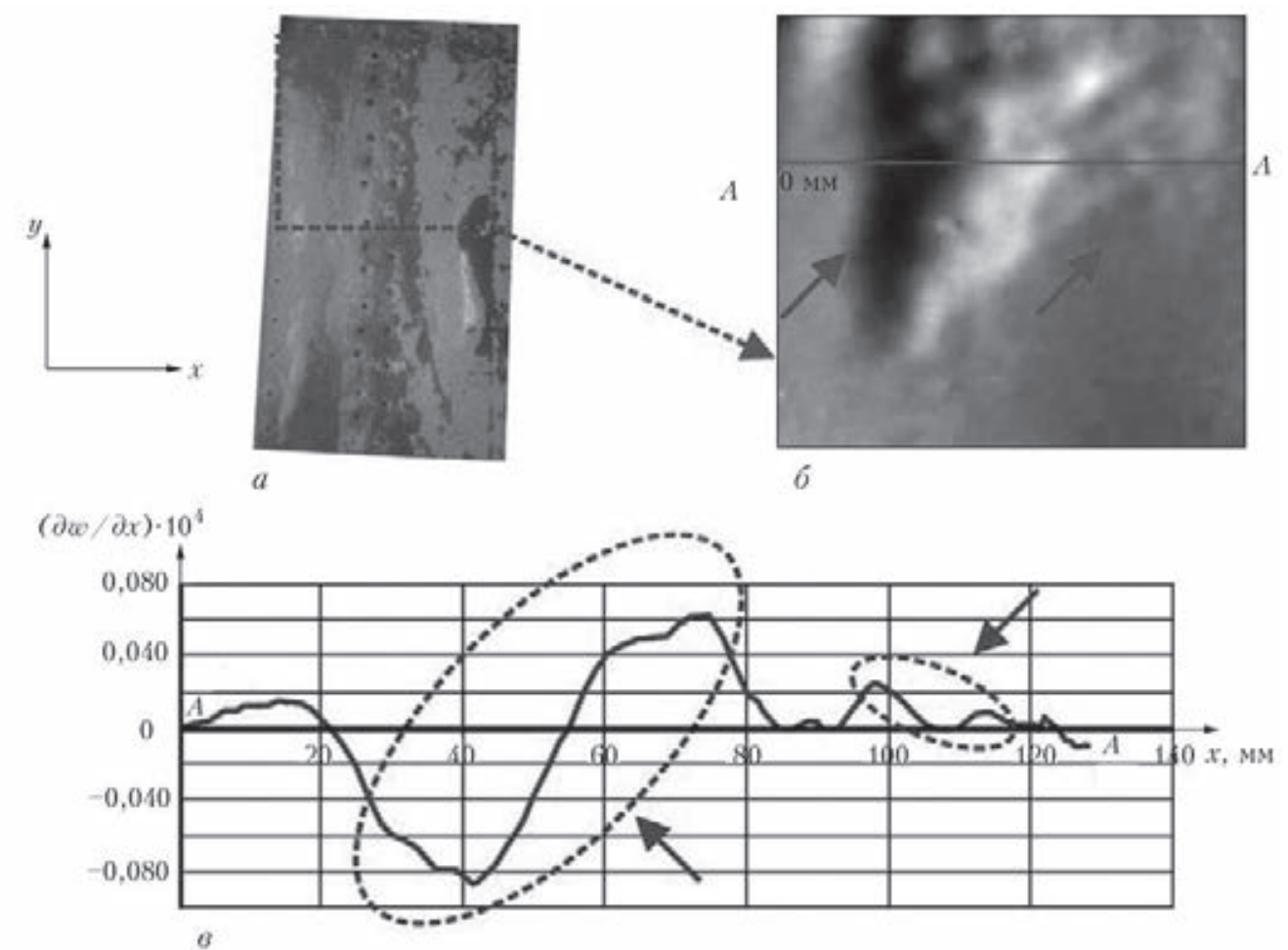

Puc. 4. Ширографический контроль биметаллического элемента с коррозионным расслоением с использованием в качестве нагружения обдува теплым воздухом $\left(T \sim 50{ }^{\circ} \mathrm{C}\right.$ в течение 5 c) на стадии нагрева: $a$ - общий вид элемента с выделенным участком контроля; $\sigma$ - поверхность деформирования контролируемого участка с выбранным сечением $A-A ; \theta-$ распределение производной $\partial w / \partial x$ вдоль выбранного сечения $A-A$ (слева - большая зона расслоения, справа - малая зона коррозионного повреждения без полного расслоения, обе выделены пунктиром и указаны стрелками)

лируемого участка поверхности элемента. После обработки в компьютере записанной оптической информации, как и в предыдущем эксперименте, получали результаты ширографического контроля качества усиливающего элемента (рис. 3). Резкий локальный скачок в распределении производной $\partial w / \partial y$ вдоль выбранных сечений характеризует наличие дефектного участка (отмечено стрелкой).

С применением технологии ширографического НКК выполнялись также эксперименты по выявлению коррозионных повреждений в биметаллических образцах из сплава Д16 и титана размерами $300 \times 170 \times 1$ мм. В процессе эксплуатации таких элементов возникали внутренние коррозионные повреждения на границе слоев алюминия (Д16) и титана в виде расслоения.

Для нагружения контролируемого образца использовали обдув воздухом, нагретым до $50{ }^{\circ} \mathrm{C}$ в течение 5 с. При выполнении экспериментов величина широсдвига составляла 5 мм вдоль направления оси $O X$. Полученные результаты, характеризующие деформирование контролируемого образца вдоль выбранного сечения, приведены на рис. 4. Локальные изменения величины и знака производной $\partial w / \partial x$ вдоль выбранного сечения $A-A$, характеризуют наличие коррозионного повреждения на границе слоя Д16-титан (рис. 4, в).

Проведенные исследования и эксперименты подтверждают эффективность применения мето- да электронной ширографии для выявления различных типов коррозионных дефектов (утонение, расслоение, трещина) в элементах и узлах авиационных конструкций.

\section{Выводы}

Ширография применяется как оперативный и надежный метод контроля тонколистовых элементов конструкций, изготовленных из металлических материалов. Метод может использоваться на всех стадиях контроля: от процесса производства конструкций до их эксплуатации, как при техническом обслуживании, так и при их ремонте.

Важным преимуществом электронной ширографии при проведении НК качества объектов является то, что в отличие от традиционных методов контроля, которые только фиксируют наличие или отсутствие дефектов, метод ширографии позволяет выявлять концентрацию напряжений, которая обусловлена присутствием дефекта или конструктивными особенностями исследуемого объекта.

Проведенные исследования и эксперименты позволили с применением электронной ширографии выявить внутренние дефекты в элементах обшивки фюзеляжа и крыла самолета без демонтажа внутренней облицовки и герметика. При проведении экспериментов с использованием термического нагружения в исследуемых элементах были выявлены дефекты как в виде утонения и расслоения, так и в виде трещин. 
1. Fahr A. Aeronautical Applications of Non-destructive Testing // Canada. - 2014. - P. 82-85.

2. Ball D. L. The Role of Nondestructive Testing in Aircraft Damage Tolerance // Materials Evaluation. - 2003. - № 7. - P. 814-818.

3. NDE of Composite Structures using Ultrasonic, Thermography and Laser Shearography / M. Genest, M. Brothers, R. LeBlanc, A. Fahr // Proc. of SAMPE Conference, Seattle, WA, May 17-20, 2010.

4. Pulsed Thermography and Laser Shearography for Damage Growth Monitoring / M.Genest, R.S. Rutledge, R. Koteri et al. // Proc. of the International Workshop on Smart Materials, Structures \& NDT in Aerospace, Montreal, Quebec. - Canada, Nov. 2-4, 2011
5. Игнатович С. Р. Надежность выявления трещин при неразрушающем контроле авиационных компонентов // Дефектоскопия. - 2013. - 49, №5. - С. 69-76.

6. Steinchen W., L. Yang L. Digital Shearography Theory and Application of Digital Speckle Pattern Shearing Interferometry // SPIE - The International Society of Optical Engineering, Bellingham, Washington, 2003.

7. ASTM Standard Practice E-2581-7 Shearography of Polymer Matrix Composites, Sandwich Core Materials and Filament-Wound Pressure Vessels in Aerospace Application. http://www.astm.org/Standard/index.shtml.

8. Технология неразрушающего контроля качества элементов и узлов авиационных конструкций методом электронной ширографии / Л.М. Лобанов, В.А. Знова, В.А. Пивторак, И.В. Киянец // Техн. диагностика и неразруш. контроль. - 2014. - № 3. - С. 15-18.

Technology of monitoring corrosion damage in the form of thinning and cracks in aircraft structure elements by the method of electron shearography was developed. The method allows revealing stress concentration, due to presence of defects or structural features of the studied object. Effectiveness of shearography application to detect corrosion damage of various types, dimensions and shape, is demonstrated in experiments both on test samples and on full-scale elements of airframe skin and aircraft wing without dismantling the internal facing or sealant. 8 References, 4 Figures

Keywords : nondestructive quality testing, quality, aircraft structure diagnostics, shearography

\section{ФЛЭШ-РАДИОГРАФИЧЕСКИЕ ЦИФРОВЫЕ ВЫСОКОЧУВСТВИТЕЛЬНЫЕ ПОРТАТИВНЫЕ РЕНТГЕНТЕЛЕВИЗИОННЫЕ СИСТЕМЫ ВМЕСТО ПЛЕНОЧНОЙ РЕНТГЕНОГРАФИИ}

Для обнаружения внутренних дефектов создана портативная рентгентелевизионная аппаратура и технология, заменяющие пленочную радиографию. Впервые мгновенная (флэш) рентгентелевизионная информация в электронном виде передается по интернету или в записи на портативное запоминающее устройство (флэшку). В флэш-радиографических системах применяются высокочувствительные цифровые портативные астрологические камеры, высоко эффективные рентгеновские экраны. Такие мобильные рентгенотелевизионные системы (масса до 15 кг) имеют размер рабочего поля 120...200 мм, обеспечивают чувствительность контроля $0,8 \ldots 1 \%$ и разрешающую способность до 5 пар лин./мин. По скорости, стоимости, производительности новая технология на порядок эффективнее, чем пленочная радиография. Портативные флэш-рентгентелевизионные системы обеспечены алгоритмами для обработки и архивирования изображений, а также измерения размеров дефектов. Для создания таких систем используются технические средства, имеющиеся у заказчика, т.е. переход от традиционной пленочной радиографии к новой технологии не вызывает особых проблем.

Демонстрация возможностей флэш-радиографии на объектах заказчика выполняется бесплатно, при этом оказывается помощь в подготовке технических заданий с учетом имеющихся у заказчика: рентген-аппаратов, штативов, эталонов, ноутбуков и т.п. На рисунках для сравнения показаны фрагменты снимков с экрана ноутбука и результ пленочной радиографии.
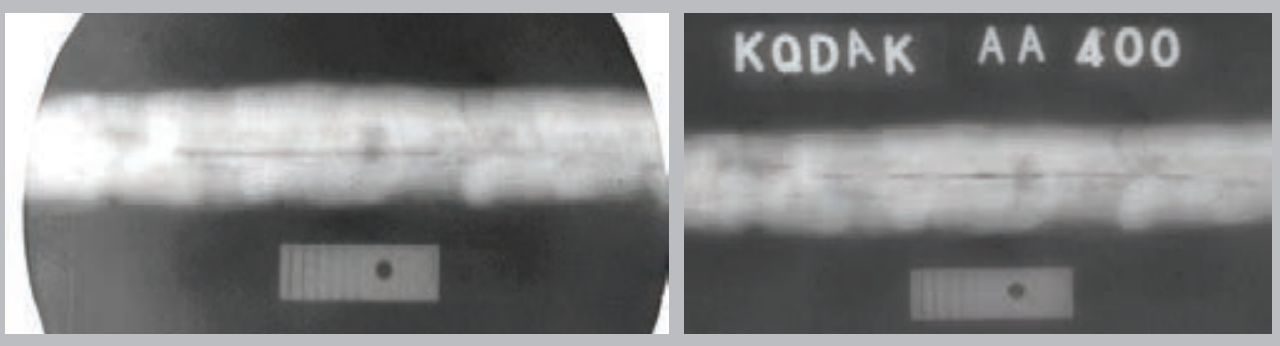

ИЭС им. Е.О. Патона НАН Украины E-mail: office@paton.kiev.ua 


\title{
МОДЕЛИРОВАНИЕ КОЛЕБАНИЙ ЧУВСТВИТЕЛЬНОЙ ПЛАСТИНКИ ПРИМЕНИТЕЛЬНО К ДАТЧИКАМ АКУСТИЧЕСКОЙ ЭМИССИИ. Сообщение 2*
}

\author{
А. Я. НЕДОСЕКА, С. А. НЕДОСЕКА \\ ИЭС им. Е.О. Патона НАНУ. 03680, г. Киев-150, ул. Боженко, 11. E-mail: office@paton.kiev.ua
}

\begin{abstract}
Рассмотрены колебания лежащих на упругой основе тонких пластинок ограниченных размеров при сосредоточенном центральном ударе по их поверхности. Принято во внимание, что сопротивление упругой основы зависит от скорости перемещения пластинки в направлении координаты $z$. Такое влияние способствует затуханию колебаний и может регулироваться в широких пределах в зависимости от свойств клеящего состава. Библиогр. 8 , рис. 8.
\end{abstract}

Ключев в е слова: неразрушающий контроль, системы акустической эмиссии, колебания тонкой пластинки, метод интегральных преобразований

В настоящей работе авторы продолжили использовать метод интегральных преобразований для решения задачи колебаний тонкой пластинки при различных условиях закрепления и наличия сопротивления упругой подложки ее колебаниям. Эта задача важна для разработчиков акустических датчиков, а в нашем случае - датчиков акустической эмиссии (АЭ). Метод интегральных преобразований можно отнести к математическому моделированию, когда законы протекания физических процессов при колебаниях могут быть представлены рядом математических операторов, а главное, весь процесс колебаний может быть расчленен на элементарные составляющие с сохранением физического смысла каждого такого элемента. Произведя далее все необходимые действия по расчету и согласованию параметров, характеризующих явление, можно приступить к сборке элементарных составляющих и анализировать явление уже в целом в замкнутом виде. Используя этот метод, нам удалось решить ряд сложных задач, не поддававшихся решению обычными прямыми методами. Удалось вскрыть и проанализировать ранее завуалированные процессы, протекающие в материалах при их возбуждении.

Математическое моделирование является достаточно сложной задачей анализа физических процессов математическими методами. Особенность моделирования заключается в наиболее удачном и близком к реальным условиям выборе основных исходных данных, выборе модели, описывающей процесс, и как можно более точном представлении граничных и начальных условий задачи. Наиболее перспективным, имеющим достаточную гибкость методом решения таких задач в настоящее время и является метод интегральных преобразований.
Ниже представлена технология применения этого метода для задач колебания тонких пластинок, применяемых в АЭ датчиках.

Известно, что одним из самых важных элементов систем АЭ являются датчики, воспринимающие колебания элементов контролируемой конструкции, преобразующие эту информацию в электрические сигналы и передающие их далее в прибор для последующей обработки. Главным элементом АЭ датчика является жесткая пластинка - генератор акустических сигналов (рис. 1). От рода сигналов, генерирующих этой пластинкой, существенно зависит сложность программного обеспечения аппаратуры АЭ и быстродействие ее работы в режиме регистрации сигналов и оценки состояния контролируемой конструкции. Немаловажно также знать, какую информацию будет передавать пластина, работая в качестве генератора сигналов в режиме сканирования деформирующегося материала конструкции. Полагаем, что существенную роль в этом процессе играет способ закрепления пластинки в датчике, ее размеры и расположение [1-5]. Последнее приводит к появлению и других типов колебаний, таких как продольные и поперечные колебания массы пластинки, приводящие к изменению ее толщины. В данной работе мы рассмотрим колебания только изгибного типа тонких пластинок с отношением диаметра к толщине 10 и более.

Ранее [6] мы анализировали колебания пластинок ограниченного диаметра в предположении отсутствия затухания колебаний с течением времени. Однако в действительности силы крепления пластинки к основанию датчика имеют способностью «гасить» колебания с течением времени за счет рассеяния энергии, приводящей к возникновению колебательного процесса в кле-

\footnotetext{
$\overline{\text { * Сообщение } 1}$ см. в журнале «Техническая диагностика и неразрушающий контроль». - 2015. - №1 . - С. 17-22.
}

(C) А. Я. Недосека, С. А. Недосека, 2015 
евом промежуточном слое. Этот процесс может быть описан динамическим коэффициентом зату-

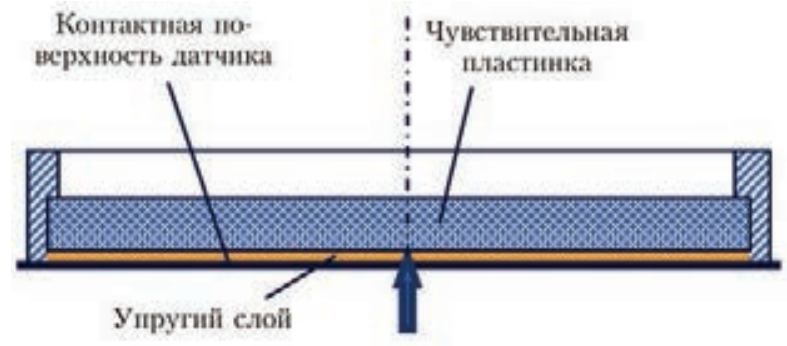

Puc. 1. Наклеенная и защемленная по контуру пластинка в корпусе АЭ датчика (схема)
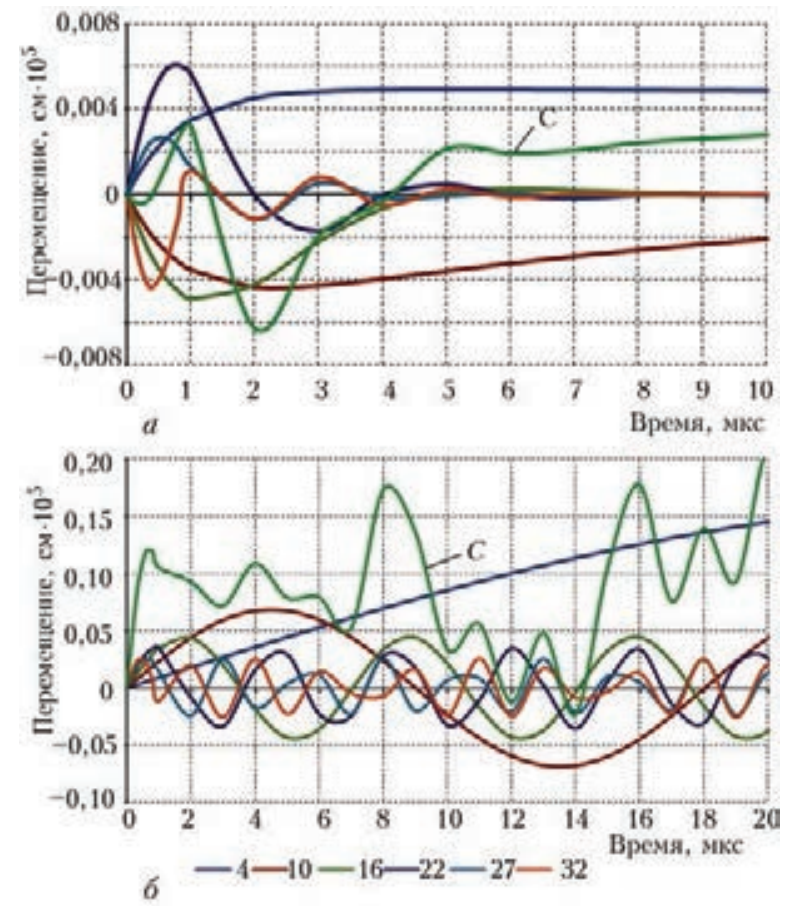

Puc. 2. Затухающие (a) и незатухающие (б) колебания защемленной по контуру пластинки толщиной 1 мм и диаметром 11 мм в зависимости от времени. Представлены суммарные колебания $C$ по выделенным волновым числам и колебания по элементарным волновым числам, показанными под графиком

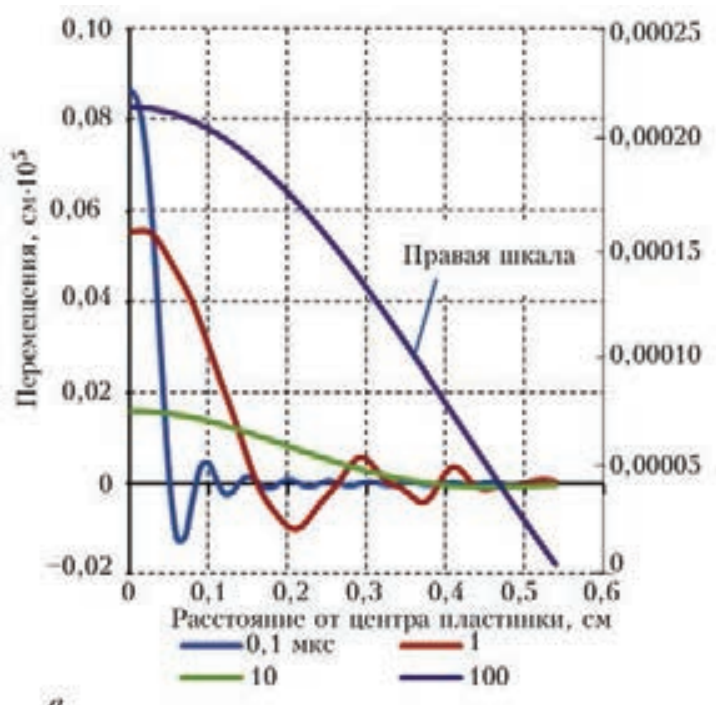

хания $k_{\text {д, }}$ кгс/ $\mathrm{cm}^{3}$. В этом случае дифференциальное уравнение колебаний пластинки при различных заданных граничных и начальных условиях может быть записано [1] в виде:

$$
\nabla^{2} \nabla^{2} w+\frac{k}{D} \frac{\partial w}{\partial t}+\beta^{4} \frac{\partial^{2} w}{\partial t^{2}}=\frac{Q}{2 \pi D r} \delta(r) \delta(t),
$$

где $w$ - прогиб пластины в направлении оси $z$, см; $r$ - радиус вдоль поверхности пластины, см; $t$ - текущее время, с; $D=E \delta^{3} / 12\left(1-v^{2}\right)$ - цилиндрическая жесткость пластины, кг.см; $v$ - коэффициент Пуассона; $\delta$ - толщина пластинки, см; $Q$ - импульсно приложенная в центре пластинки сила, кгс; $\delta(r)$ и
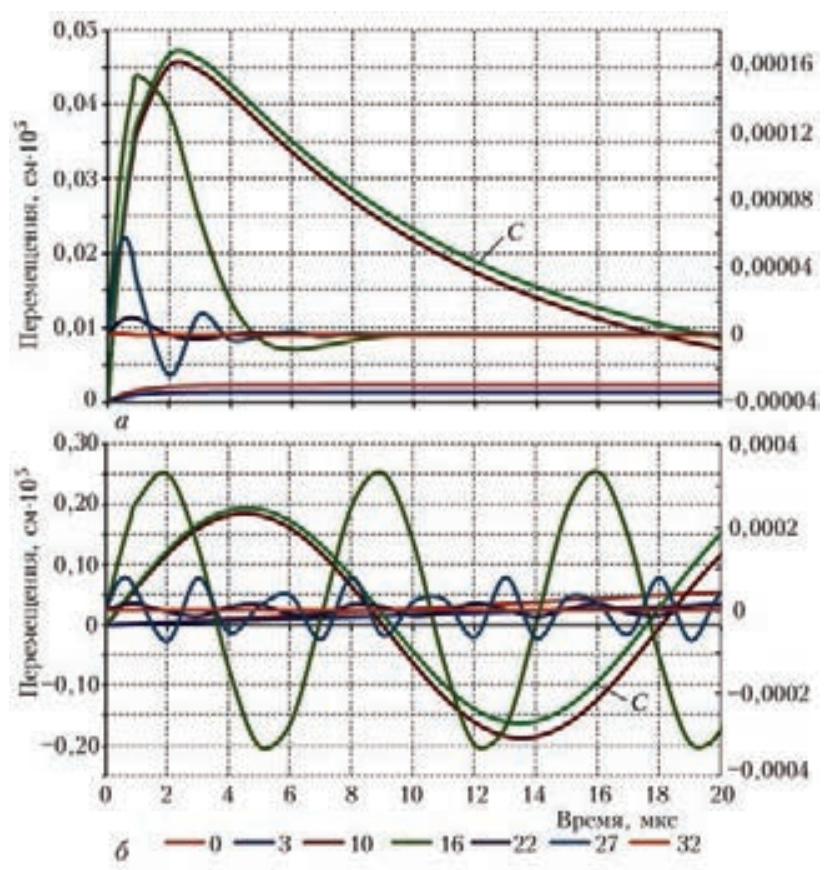

$P u c .4$. Затухание колебаний приклеенной свободной пластинки толщиной 1 мм и диаметром 11 мм в зависимости от времени $(a)$ и колебания без затухания (б). Представлено суммарное колебание $C$ по выделенным волновым числам и колебания по элементарным волновым числам, показанными под графиком. Правая шкала построена для значений $\alpha_{n}=16 ; 22 ; 27 ; 32 \mathrm{~cm}^{-1}$

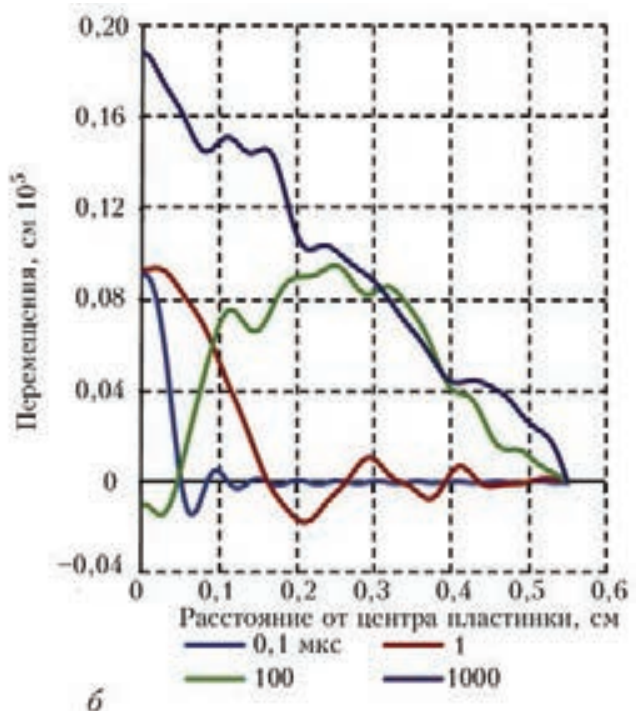

Puc. 3. Распределение вдоль радиуса затухающих колебаний защемленной и приклеенной пластинки толщиной 1 мм диаметром 11 мм $(a)$ и такой же пластинки без затухания (б) 
$\delta(t)$ - импульсные функции Дирака, характеризующие сосредоточенность и мгновенность приложения нагрузки $Q$.

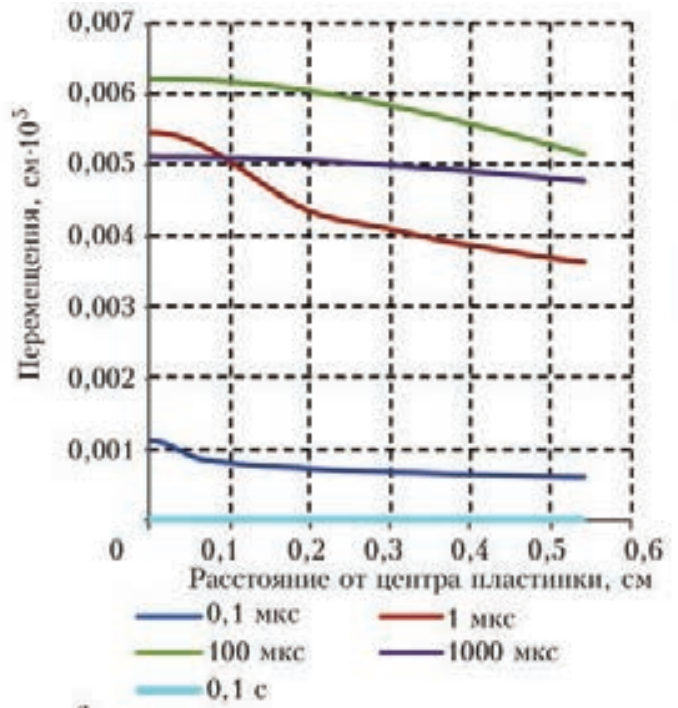

Проведя интегральные преобразования Лапласа и Ханкеля дифференциального уравнения (1), получим:

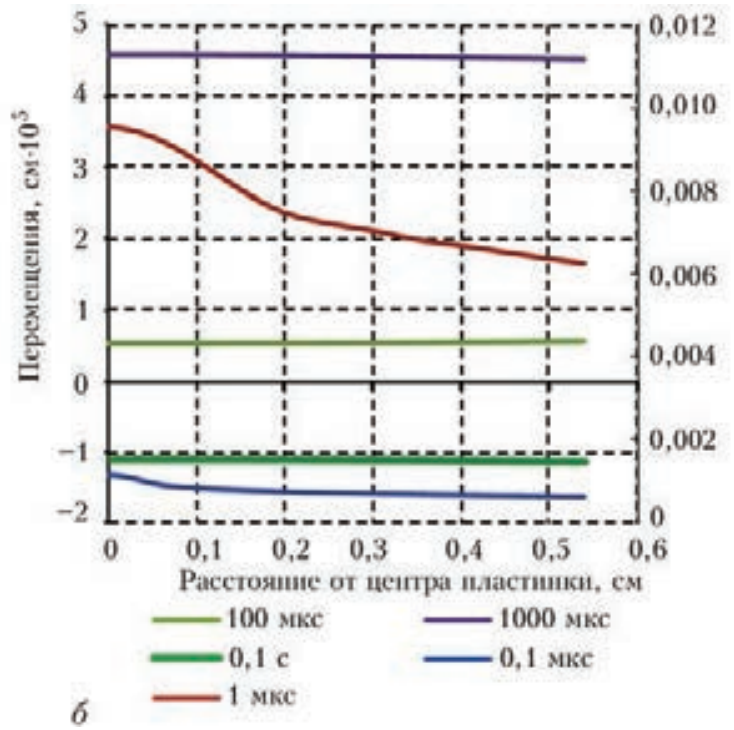

Puc. 5. Колебания пластинок, приклеенных к контактной поверхности датчика АЭ и свободных от краевого закрепления: $a-\mathrm{c}$ затуханием колебаний; $\sigma$ - без затуханий (правая шкала для времени 0,1 и 1 мкс)

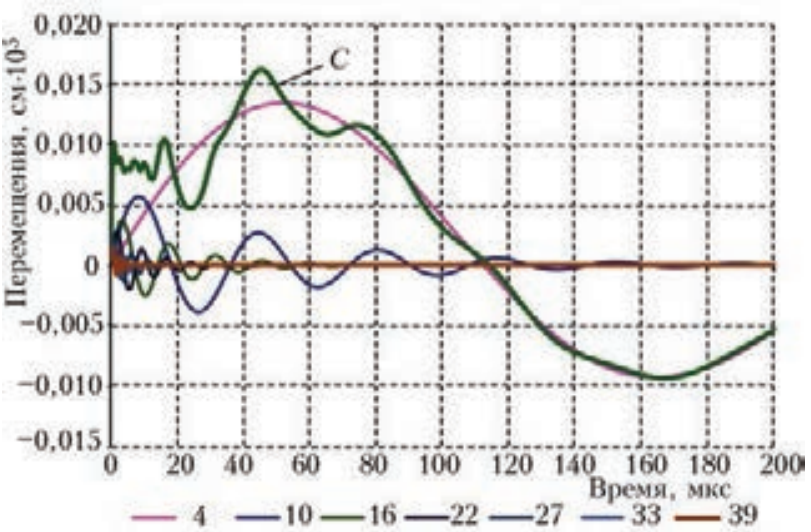

Puc. 6. Колебания защемленной и приклеенной пластинки в точке $r=0$ в зависимости от волнового числа $\alpha_{n}$ и времени; $C$ - суммарное значение амплитуды колебаний для волновых чисел, представленных под графиком

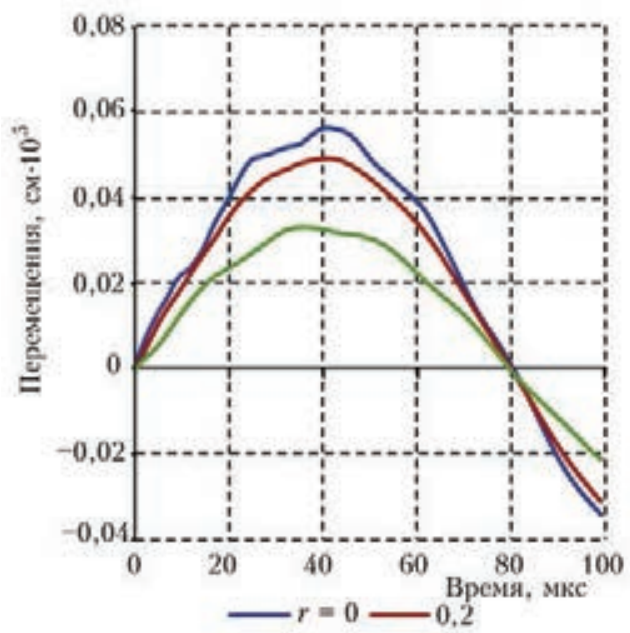

$a$

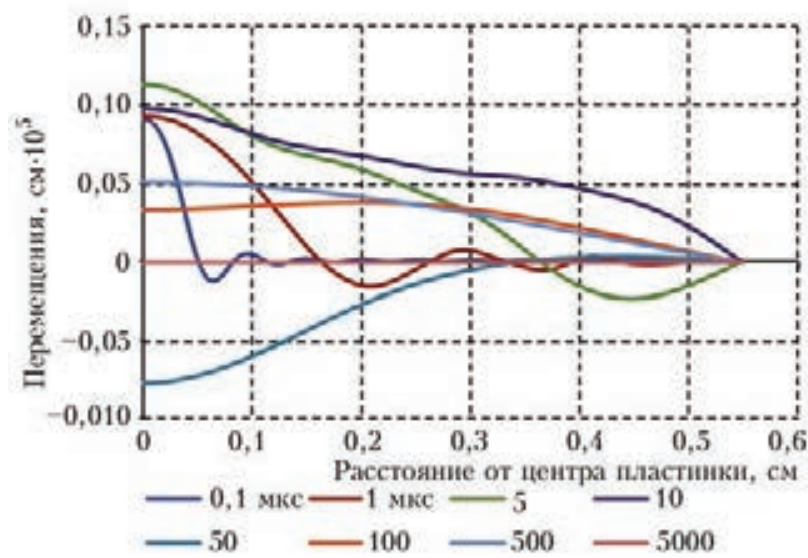

Puc. 7. Колебания круглой наклеенной пластинки с защемленным контуром с зависящим от волнового числа коэффициентом затухания (диаметр пластинки 11 мм, толщина 1 мм)

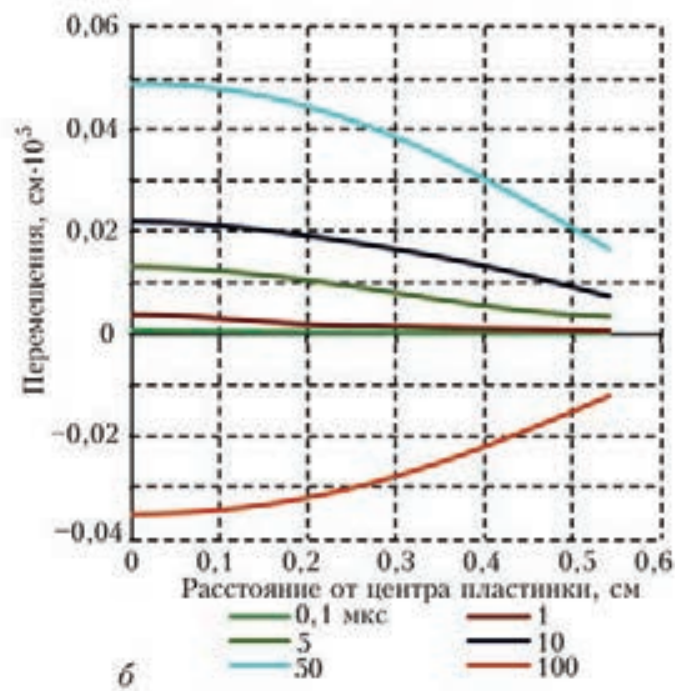

Puc. 8. Колебания круглой наклеенной пластинки со свободным контуром с зависящим от волнового числа коэффициентом затухания (диаметр пластинки 11 мм, толщина 1 мм) в зависимости от времени (a) и расстояния от центра пластинки (б) 


$$
\begin{aligned}
& \left(\alpha^{4}+\frac{k_{\text {д }}}{D} p+\beta^{4} p^{2}\right)=\bar{w}=\frac{Q}{2 \pi D}, \\
& =\bar{w}=\frac{Q}{2 \pi D} \frac{1}{\alpha^{4}+\frac{k_{\text {д }}}{D} p+\beta^{4} p^{2}} .
\end{aligned}
$$

Рассмотрим два случая крепления пластинки в корпусе АЭ датчика на клеевой основе с защемленным контуром и пластинки, приклеенной к основе со свободным контуром, и случай 3 , когда реакция упругой подложки зависит от частоты колебаний пластинки.

Случай 1. В этом случае с учетом [6] граничные и начальные условия могут быть записаны в виде:

$w=0, \partial w / \partial r \neq 0$ при $r=r_{0}$ и $w=0$ при $t=0$.

Обратное преобразование Лапласа представленного выше выражения будет [7]:

$$
\begin{gathered}
\bar{w}=\frac{Q}{2 \pi D \beta^{2}} \exp \left(-\frac{k_{\text {д }} t}{2 D \beta^{4}}\right) \frac{\operatorname{sh}\left(\frac{t}{\beta^{2}} \sqrt{\frac{k_{\text {д }}^{2}}{4 D^{2} \beta^{4}}-\alpha_{n}^{4}}\right)}{\sqrt{\frac{k_{\text {д }}^{2}}{4 D^{2} \beta^{4}}-\alpha_{n}^{4}}}, \\
\bar{w}=\frac{Q}{2 \pi D \beta^{2}} \exp \left(-\frac{k_{\text {д }} t}{2 D \beta^{4}}\right) \frac{\sin \left(\frac{t}{\beta^{2}} \sqrt{\alpha_{n}^{4}-\frac{k_{\text {д }}^{2}}{4 D^{2} \beta^{4}}}\right)}{\sqrt{\alpha_{n}^{4}-\frac{k_{\text {д }}^{2}}{4 D^{2} \beta^{4}}}} .
\end{gathered}
$$

Формула (2) показывает, что в начальный период, когда волновое число $\alpha_{n}{ }_{n}^{4}$ меньше $\frac{k_{д}^{2}}{4 D^{2} \beta^{4}}$, характеризующего процесс затухания, то колебательного процесса не существует. Имеется только рост амплитуды в соответствии с показаниями гиперболического синуса. Как только величина $a_{n}{ }^{4}$ станет больше $\frac{k_{\text {д }}^{2}}{4 D^{2} \beta^{4}}$, начинается постепенно затухающий колебательный процесс. Полученное преобразование Лапласа является общим для всех случаев крепления пластинки.

Обратное преобразование по $r$ для первого случая выполним, применив формулу конечных преобразований Ханкеля, когда искомая величина представляется в виде бесконечного ряда по конкретным значениям спектральных чисел $\alpha_{n}$, полученным из уравнения $J_{0}\left(\alpha_{n} r_{0}\right)=0[1-6]$ :

$$
w=\frac{2}{r_{0}^{2}} \sum_{n=1}^{\infty} \frac{1}{J_{1}^{2}\left(\alpha_{n} r_{0}\right)} \bar{f}\left(\alpha_{n}\right) J_{0}\left(\alpha_{n} r_{0}\right) \text {. }
$$

Здесь $\bar{f}\left(\alpha_{n}\right)$ - изображение оригинала.

Тогда в соответствии с приведенной формулой и с учетом граничных условий получим:

$$
\begin{aligned}
& w=\frac{Q}{\pi D \beta^{2} r_{0}^{2}} \times \\
& \begin{array}{c}
\times \sum_{n=1}^{\infty} \frac{\exp \left(-\frac{k_{\text {д }}}{2 D \beta^{4}}\right) \operatorname{sh}\left(\frac{t}{\beta^{2}} \sqrt{\frac{k_{\text {д }}^{2}}{4 D^{2} \beta^{4}}-\alpha_{n}^{4}}\right)}{J_{1}^{2}\left(\alpha_{n} r_{0}\right) \sqrt{\frac{k_{\text {д }}^{2}}{4 D^{2} \beta^{4}}-\alpha_{n}^{4}}} J_{0}\left(\alpha_{n} r\right), \\
w=\frac{Q}{\pi D \beta^{2} r_{0}^{2}} \times
\end{array} \\
& \times \sum_{n=1}^{\infty} \frac{\exp \left(-\frac{k_{\text {д }} t}{2 D \beta^{4}}\right) \sin \left(\frac{t}{\beta^{2} \sqrt{\alpha_{n}^{4}-\frac{k_{\text {I }}^{2}}{4 D^{2} \beta^{4}}}}\right)}{J_{1}^{2}\left(\alpha_{n} r_{0}\right) \sqrt{\alpha_{n}^{4}-\frac{k_{\text {I }}^{2}}{4 D^{2} \beta^{4}}}} J_{0}\left(\alpha_{n} r\right) .
\end{aligned}
$$

Используя формулы (4), построим графики затухания колебаний в зависимости от времени. Интересно отметить, что затухание колебаний пластинки зависит от волнового числа $\alpha_{n}, \mathrm{~cm}^{-1}$. Чем больше число $\alpha_{n}$, тем быстрее происходит затухание колебаний, связанных с этим числом. Частота колебаний $f_{n}$ связана с $\alpha_{n}$ следующим соотношением: $f_{n}=$ $=\alpha_{n}{ }^{2} / 2 \pi \beta^{2}$. Другими словами, чем больше волновое число $\alpha_{n}$, тем больше частота колебаний элементарных составляющих перемещений. Частота колебаний и волновое число являются величинами дискретными и определяются спектральным уравнением $J_{0}\left(\alpha_{n} r_{0}\right)=0$.

Как видно из графиков (рис. 2), спектральный состав двух случаев расчета различен. На рис. 2, б видны спектральные составляющие колебаний, которые не затухают с течением времени. В то же время рис. 2, а показывает, что колебания достаточно интенсивно затухают и чем больше волновое число, тем выше степень их затухания.

Распределение перемещений пластинки в направлении оси $z$ для случая затухающих колебаний приведены на рис. 3. Анализируя эти графики, видим, что колебания двух представленных вариантов пластинок при одном и том же закреплении существенно отличаются, если время превышает 1 мкс. Последнее необходимо учитывать, если расчеты выполняются по формулам, не учитывающим влияние затухания колебаний с течением времени, что характерно для вариантов, когда значение коэффициента затухания $k_{д}$ неизвестно.

Случай 2. Если пластинка приклеена в контактной поверхности АЭ датчика со свободным от закрепления контуром, то граничные условия задачи становятся другими. В этом случае необходимо, чтобы изгибающие моменты на свободном контуре пластинки были равны нулю [6]. Поэтому обратное преобразование Ханкеля может быть также выполнено по формуле конечного преобра- 
зования, но при других условиях отыскания значений $\alpha_{n}$, таких, при которых граничные условия решаемой задачи будут удовлетворены. Удовлетворив граничным условиям, получим [6]:

$$
\begin{aligned}
& w=\frac{Q}{\pi D \beta^{2} r_{0}^{2}} \sum_{n=1}^{\infty} \frac{\exp \left(-\frac{k_{\text {д }} t}{2 D \beta^{4}}\right)}{\left[1+\frac{\alpha_{n}^{2} r_{0}^{2}}{(1+v)^{2}}\right]} \ldots \times \\
& \times \ldots \frac{\operatorname{sh}\left(\frac{t}{\beta^{2}} \sqrt{\frac{k_{\text {д }}^{2}}{4 D^{2} \beta^{4}}-\alpha_{n}^{4}}\right) J_{0}\left(\alpha_{n} r\right)}{J_{0}^{2}\left(\alpha_{n} r_{0}\right) \sqrt{\frac{k_{\text {д }}^{2}}{4 D^{2} \beta^{4}}-\alpha_{n}^{4}}}, \\
& w=\frac{Q}{\pi D \beta^{2} r_{0}^{2}} \sum_{n=1}^{\infty} \frac{\exp \left(-\frac{k_{\text {д }} t}{2 D \beta^{4}}\right)}{\left[1+\frac{\alpha_{n}^{2} r_{0}^{2}}{(1+v)^{2}}\right]} \ldots \times \\
& \times \ldots \frac{\sin \left(\frac{t}{\beta^{2}} \sqrt{\left.\alpha_{n}^{4}-\frac{k_{\text {д }}^{2}}{4 D^{2} \beta^{4}}\right) J_{0}\left(\alpha_{n} r\right)}\right.}{\left.J_{0}^{2}\left(\alpha_{n} r_{0}\right)\right) \sqrt{\alpha_{n}^{4}-\frac{k_{\text {д }}^{2}}{4 D^{2} \beta^{4}}}} .
\end{aligned}
$$

Спектральное уравнение для этого случая будет: $h J_{0}\left(\alpha_{n} r_{0}\right)+a_{n} J_{1}\left(\alpha_{n} r_{0}\right)=0$; из граничных условий $\mathrm{h}=\mathrm{a}_{\mathrm{n} 0}^{2} \mathrm{r}_{0} /(1+\mathrm{v})$.

Результаты расчетов по формулам (5) представлены на графиках рис. 4. Видно, что наличие демпфирующей среды приводит к быстрому уменьшению амплитуд колебаний пластинок. При этом существенное различие в колебательных процессах в обоих случаях появляется в момент начала колебаний.

Анализ графиков рис. 5 показывает существенные различия в колебаниях пластинок свободно приклеенных к контактной поверхности АЭ датчика. Демпфирующий слой клея вызывает быстрое затухание амплитуд сигналов АЭ. Рис. 5, б показывает, что наличие упругого основания без демпфирования для крепления пластинки приводит к тому, что ее колебания протекают практически без затухания.

Случай 3. Следует отметить, что расчет колебаний пластинок в некоторых случаях затруднителен из-за незнания конкретных значений коэффициента затухания $k_{\text {д }}$ Экспериментальные данные по величинам этого коэффициента сегодня отсутствуют. Поэтому целесообразно попытаться в расчет ввести не экспериментальные значения $k_{\text {д }}$ а значения, основанные на физических константах, имеющихся в современных справочниках. Если принять во внимание размерность коэффициента $k_{\text {д }}$ то его значение для рассматриваемого случая может быть представлено в следующем виде ${ }^{1}$ :

$$
k_{\alpha}^{*}=\alpha_{n}^{2} \beta_{\kappa}^{2} D_{\kappa}, \kappa г \mathrm{c} / \mathrm{cm}^{3} .
$$

Как видно, величина коэффициента $k_{\alpha}$ в предлагаемом варианте зависит от волнового числа $\alpha_{n}^{2}$, коэффициентов $\beta_{\text {к }}^{2}$ и $D_{\text {к }}$, характеризующих способность подложки поглощать энергию колебаний пластинки ${ }^{2}$. Проведя анализ размерностей физических величин, входящих в выражение (6),

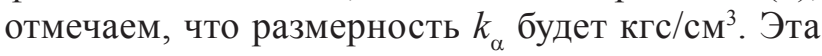
размерность полностью соответствует размерно-

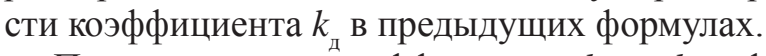

Проведя замену коэффициента $k_{д}$ на $k_{\alpha}$ в формуле (4), получаем следующее выражение для расчета перемещений $w$ в этом варианте:

$$
\begin{gathered}
w=\frac{Q}{\pi D \beta^{2}} \sum_{n=1}^{\infty} \frac{\exp \left(-\frac{\alpha_{n}^{2} \beta_{\mathrm{K}}^{2} D_{\mathrm{K}} t}{2 D \beta^{4}}\right)}{\alpha_{n}^{2} r_{0}^{2} J_{1}^{2}\left(\alpha_{n} r_{0}\right)} \ldots \times \\
\times \ldots \frac{\sin \left[\frac{\alpha_{n}^{2} t}{\beta^{2}} \sqrt{1-\left(\frac{\beta_{\mathrm{K}}^{2} D_{\mathrm{K}}}{2 D \beta^{2}}\right)^{2}}\right]}{\sqrt{1-\left(\frac{\beta_{\mathrm{K}}^{2} D_{\mathrm{\kappa}}}{2 D \beta^{2}}\right)^{2}}} J_{0}\left(\alpha_{n} r\right), \\
J_{0}\left(\alpha_{n} r_{0}\right)=0 .
\end{gathered}
$$

Сравнивая графики, представленные на рис. 2, 6 и 6, видим, что амплитуды колебаний отличаются. Суммарные значения амплитуд не похожи одна на другую, хотя затухание процесса колебаний отличается незначительно. В то же время обе методики расчета дают похожие результаты и эксперимент должен уточнить, какая из методик наиболее приемлема. На графиках рис. 7 приведены результаты расчета колебаний защемленной и наклеенной пластинки в зависимости от расстояния до центра излучения и времени. Можно наблюдать, что колебания пластинки стали более плавными по сравнению с рис. $3, a$, хотя сравнивать графики достаточно сложно из-за трудности сопоставления коэффициентов затухания в обоих случаях.

Физические постоянные, принятые во всех приведенных расчетах с учетом $[6,8]: E_{k}=50$ МПа; $\rho_{k}=1,05 \cdot 10^{-3}$ кг $/ \mathrm{cm}^{3} ; v_{k}=0,48 ; D_{k}=0,06 \kappa \Gamma \cdot \mathrm{cм} ;$ $\beta_{k}^{2}=0,00134 \mathrm{c} / \mathrm{cm}^{2} ; E=5 \cdot 10^{3} \mathrm{MПа} ; \rho=3,7 \cdot 10^{-3} \mathrm{\kappa} / \mathrm{cm}^{3}$; $g=0,981 \cdot 10^{3} \mathrm{~cm} / \mathrm{c}^{2} ; Q=1 \cdot 10^{-8} \kappa \Gamma \cdot \mathrm{c} ; k_{\text {д }}=0,458 \kappa \Gamma / \mathrm{cm}^{3}$,

$$
\begin{aligned}
& \beta^{2}=\sqrt{\frac{\rho \delta}{g D}}=287 \cdot 10^{-6} ; 144 \cdot 10^{-6} ; 95,7 ; \\
& 71,8 ; 48 \cdot 10^{-6} \mathrm{c} / \mathrm{cm}^{2}
\end{aligned}
$$

для $\delta=0,1 ; 0,2 ; 0,30,4 ; 0,6 \mathrm{~cm}$;

\footnotetext{
${ }^{1}$ Величина $k_{\alpha}$ введена, чтобы избежать путаницы в обозначениях ${ }^{2}$ Индекс «к» означает обобщенное понятие подложки или клея
} 


$$
D=\frac{E \delta^{3}}{12\left(1-v^{2}\right)}=4,58 ; 36,6 ; 123,6 ; 293 ; 989 \mathrm{\kappa \Gamma} \cdot \mathrm{cm}-
$$

для $\delta=0,1 ; 0,2 ; 0,3 ; 0,4 ; 0,6 \mathrm{~cm}$

Рассматривая колебания пластинки, приклеенной к контактной поверхности АЭ датчика со свободным от ограничений контуром, можно сделать вывод, что ее колебания при $\alpha_{n}=0$ отсутствуют и для этого случая

$$
w=\frac{Q}{\pi D \beta^{4} r_{0}^{2}} t
$$

Это выражение показывает, что пластинка просто перемещается параллельно самой себе, не встречая сопротивления клеевой прослойки $\left(k_{\alpha}=0\right.$, так как $\left.\alpha_{n}=0\right)$. В действительности этого не происходит, поскольку прослойка имеет определенную упругость и возвращает квазистатическое перемещение пластинки с течением времени в исходное состояние. Этот процесс может быть оценен по следующей формуле:

$$
w=\frac{2 Q}{\pi k_{\text {д }} r^{2}}\left[\frac{1}{2}-\exp \left(-\frac{k_{\text {д }} t}{2 D \beta^{4}}\right) \operatorname{sh}\left(\frac{k_{\text {д }} t}{2 D \beta^{4}}\right)\right] .
$$

Остальные перемещения пластинки для $\alpha_{n}>0$ носят колебательный характер и рассчитываются по формуле:

$$
\begin{aligned}
& w=\frac{Q}{\pi D \beta^{2}} \sum_{n=1}^{\infty} \frac{\exp \left(-\frac{\alpha_{n}^{2} \beta_{\mathrm{K}}^{2} D_{\mathrm{K}} t}{2 D \beta^{2}}\right)}{\alpha_{n}^{2} r_{0}^{2}\left(1+\frac{\alpha_{n}^{2} r_{0}^{2}}{(1+v)^{2}}\right)} \ldots \times \\
& \times \ldots \frac{\sin \left[\frac{\alpha_{n}^{2} t}{\beta^{2}} \sqrt{1-\left(\frac{\beta_{\mathrm{K}}^{2} D_{\kappa}}{2 D \beta^{2}}\right)^{2}}\right] J_{0}\left(\alpha_{n} r\right)}{J_{0}^{2}\left(\alpha_{n} r_{0}\right) \sqrt{1-\left(\frac{\beta_{k}^{2} D_{k}}{2 D \beta^{2}}\right)^{2}}},
\end{aligned}
$$

$h J_{0}\left(\alpha_{n} r_{0}\right)+a_{n} J_{1}\left(\alpha_{n} r_{0}\right)=0$; из граничных условий $\mathrm{h}=\mathrm{a}_{\mathrm{n}}^{2} \mathrm{r}_{0} /(1+\mathrm{v})$.
На рис. 8 представлены такие колебания в зависимости от времени $t$ и радиуса $r$. Для выполнения расчетов, как и ранее, была создана специальная программа с выводом получаемых результатов в Exel для построения и редактирования графиков и таблиц. Программа позволяла в широких пределах проводить анализ полученной информации для более глубокого изучения сущности процессов, протекающих в пластинках, в зависимости от влияния тех или иных факторов.

\section{Выводы}

На основе конечных интегральных преобразований Ханкеля и преобразований Лапласа получены аналитические зависимости для расчета колебаний тонких пластинок ограниченных размеров с учетом затухания колебаний с течением времени. Полученные аналитические зависимости позволяют рассчитывать колебания пластинок при различных способах их закрепления.

Предложена физическая величина коэффициента затухания, зависящая от волновых чисел (частоты колебаний), жесткости и вязкости соединительного слоя, крепящего чувствительную пластинку к контактной поверхности АЭ датчика.

1. Недосека А. Я. Основы расчета и диагностики сварных конструкций / Под ред. Б.Е. Патона. - Киев: Индпром, 2008. $-815 \mathrm{c}$.

2. Акустическая эмиссия и ресурс конструкций / Б.Е. Патон, Л.М. Лобанов, А.Я. Недосека и др. - Киев: Индпром, 2012. $-312 \mathrm{c}$.

3. Тимошенко С. П. Сопротивление материалов. - М.: Физматгиз. - Т.1, 1960. - 380 с.; Т.2, 1965. - 480 с.

4. Тимошенко С. П. Колебания в инженерном деле. - М.: Наука, 1967. - 444 с.

5. Тимошенко С. П., Войновский-Кригер С. Пластинки и оболочки. - М.: Физматгиз, 1963. $-636 \mathrm{c.}$

6. Недосека А. Я., Недосека С. А. Моделирование колебаний чувствительной пластинки применительно к датчикам акустической эмиссии. Сообщение 1. // Техн. диагностика и неразруш. контроль. - 2015. - № 1. - С. 17-22.

7. Деч Г. Руководство к практическому применению преобразования Лапласа и Z-преобразования. - М.: Наука, 1971. $-288 \mathrm{c}$.

8. Чайлдс У. Физические постоянные / Справ. пособие для студентов вузов. - М.: Физматгиз, 1961. - 95 с.

\begin{abstract}
Vibrations of thin plates of limited dimensions supported by an elastic base at concentrated central shock over their surface are considered. It is taken into account that elastic base resistance depends on plate displacement velocity in the direction of coordinate $z$. Such influence enhances vibration damping and can be adjusted in a broad range, depending on adhesive composition properties. 8 References, 8 Figures.
\end{abstract}

Keywords: nondestructive testing, acoustic emission system, thin plate vibrations, integral transformation method 


\title{
ЗАСТОСУВАННЯ МЕТОДУ АКУСТИЧНОЇ ЕМІСІЇ ДЛЯ ДІАГНОСТУВАННЯ КОРПУСІВ ЯДЕРНИХ РЕАКТОРІВ (ОГЛЯД)
}

\author{
Повідомлення III. Нормативна база і перспективи застосування \\ методу акустичної емісії в ядерній енергетиці
}

\author{
І.М. НЕКЛЮДОВ, З.Т. НАЗАРЧУК, В.Р. СКАЛЬСЬКИЙ, Л.Н. ДОБРОВОЛЬСЬКА \\ Фіз.-мех. ін-т ім. Г.В. Карпенка НАНУ. 79060, м. Львів, вул. Наукова, 5. E-mail: skal@ipm.lviv.ua
}

\begin{abstract}
Постійне оновлення нормативної бази діагностування корпусів реакторів АЕС відбувається на фоні кількох конкуруючих тенденцій. 3 одного боку, маємо наростаючу стурбованість старінням діючого енергогенеруючого обладнання, ресурс якого неухильно наближається до свого проектного закінчення, а з іншого - дві катастрофи, що не пов'язані 3 таким ста ᄀрінням. Катастрофа 1986 р. на Чорнобильській АЕС відбулась через суттєві недоліки конструкції та ненормативні дії обслуговуючого персоналу, а 2011 р. на японській АЕС Фукусіма - через природній катаклізм, у якому поєднались землетрус та цунамі позапроектних рівнів. І хоча згадані катастрофи завдали відчутного удару по репутації атомної енергетики, AЕС і далі залишаються одним із головних претендентів на задоволення зростаючих енергетичних потреб людства. Сучасні тенденції створення методів діагностування стану ядерного енергетичного обладнання вимагають розвитку наявної і розроблення нової нормативної бази для їх успішного застосування. Бібліогр. 41.
\end{abstract}

Ключов і слова: акустична емісія, ядерна енергетика, нормативна база діагностування

Розроблення нормативних документів щодо застосування методу АЕ. Впровадження НК, в тому числі методу АЕ на АЕС, не можна розглядати виключно з огляду науково-технічного, оскільки ця галузь особливо охоплена величезним масивом законів, постанов, рекомендацій та інших нормативних актів, без яких впровадження жодного з методів діагностування $є$ неможливим. Ядерна енергетика від початків іiі мирного застосування завжди підлягала найсуворішим юридичним вимогам, важливість ядерної безпеки усвідомлювали на найраніших стадіях проектування АЕС [1].

Більше того, світова громадськість усвідомлювала необхідність широкої міжнародної співпраці на цьому полі, внаслідок чого у 1956 р. було створено Міжнародну агенцію з атомної енергії (англійською: International Atomic Energy Agency - IAEA). Розуміючи, що майбутнє ядерної енергетики суттєво залежатиме від упевненості широкої громадськості у повній безпеці експлуатування та утилізації ядерних відпрацьованих матеріалів, IAEA від 1974 р. активно займається нормативною базою, що стосується ядерної безпеки $[1,2]$.

Постійне оновлення цієї бази відбувається на тлі кількох конкуруючих тенденцій. 3 одного боку маємо наростаючу стурбованість старінням діючого енергогенеруючого обладнання, ресурс якого щільно наближається до свого запроектованого кінця, та дві катастрофи, що не пов'язані з таким старінням. Катастрофа 1986 р. на Чорнобильській АЕС відбулась через серйозні недоліки конструкції та ненормативні дії людей, а 2011 р. на япон- ській АЕС Фукусіма - через природній катаклізм, у якому поєднались землетрус та цунамі позапроектних рівнів. 3 іншого боку, у світі наростає споживання електроенергії, що на тлі глобальних кліматичних змін стримує розвиток енергетичних потужностей на органічному паливі, а отже стимулює розвиток джерел енергії, що не супроводжуються генеруванням великих кількостей вуглекислого газу. Серед останніх, мабуть, лише ядерна енергетика зможе впродовж найближчої перспективи забезпечити значний рівень генеруючих потужностей, тоді як гідро-, вітрова, сонячна чи інші види електроенергії сьогодні можуть задовольнити лише незначний відсоток потреб.

Впродовж років IAEA створила понад 200 стандартів, що охоплюють ядерну та радіаційну безпеку, утилізацію та транспортування [1]. Bci ці документи, що створені на підставі консенсусу між нормотворчими представниками країнучасниць, формулюють мінімальний всесвітньоприйнятий рівень вимог безпеки. Кожна країна при цьому встановлює свої власні нормативи, які беруть до уваги локальні особливості та державну політику. Стандарти безпеки можна розділити на три категорії, що

- пов'язують безпеку із адмініструванням та відповідальністю за всі етапи створення та експлуатування AEC і виведення іiї з експлуатації;

- стосуються етапу проектування;

- стосуються експлуатування АЕС.

До останньої відносять всі заходи, що стосуються контролю стану обладнання АЕС, у тому числі і 
неруйнівного. Зокрема, у Вимогах Безпеки № NSR-1 [2] зазначено, що обладнання першого контуру повинно бути спроектоване, виготовлене і розташоване так, щоб упродовж терміну експлуатування енергоблоку було можливо здійснювати відповідну перевірку та випробування цілісності контуру. Крім того, слід забезпечувати спостереження процесів старіння матеріалу корпусу реактора (особливо у зоні інтенсивного опромінювання), в тому числі радіаційного і теплового окрихчування та корозійного розтріскування. Результати випробувань цілісності оболонки першого контуру повинні демонструвати відсутність: недопустимих дефектів (тобто дефектів, розмір яких перевищує критичний) та значної втрати рівня безпеки.

Як зазначає Гаттон [3] у своєму огляді, до методу AЕ на початках його застосування в ядерній енергетиці був надмірний ентузіазм, який згодом зумовив певне розчарування зацікавлених у його застосуванні суб'єктів. Це, з одного боку, зумовило значне зацікавлення державних інституцій та суттєве фінансування відповідних АЕ-досліджень i спричинило значний розвиток як фундаментальних, так і прикладних досліджень з розвитком інструментальної бази методу. У США діяла ціла програма науково-дослідних робіт, затверджена комітетом U.S. NRC, головними виконавцями якої були Pacific Northwest Laboratories та Battelle Memorial Institute [3, 4].

3 іншого боку, негативним аспектом стали передчасні намагання щодо впровадження цього методу до нормативної бази ASME, яка є обов'язковою для всіх експлуатаційників. У 1987 р. Гаттон зазначив, що справа стандартизації методу АЕ для моніторингу цілісності металу, який працює під тиском, успішно просувалась у рамках комітету E07.04 ASTM [5]. Наполеглива праця в цьому напрямку привела до появи двох стандартів ASTM E1139 [6] та E1211 [7]. Однак набагато важливішим було затвердження відповідних нормативів у розділі XI Кодексу ASME. Наполегливість Гаттона та інших учених дала свій результат. У 11 -й редакціï U.S. NRC Regulatory Guide 1.147 Inservice Inspection Code Case Acceptability ASME Section XI знаходимо статтю N-471, де викладено нормативні підходи, якими повинні користуватися під час першого та наступних застосувань AE-методу для виявлення дефектності корпусів ядерних реакторів [8]. Введення цієї норми у ASME датоване 1990 р., iї затвердження у NRC відбулось у 1992 р., а публікація - у 1994 р. Повторне затвердження у ASME відбулось у 1993 р., про що довідуємось із 12-ї редакції документу 1.147 NRC, опублікованому у 1999 р. [9].

У 1997 р. співробітники NRC у своєму огляді зазначали, що метод АЕ пройшов всі необхідні апробування і показав дієвість не тільки в лабо- раторних умовах, але і на діючих реакторах, наприклад, на реакторі станції Limerick [10]. У 2000 p. вийшов додаток до V розділу Кодексу ASME редакції 1998 р. [11]. У ньому чотири статті присвячені впровадженню методу АЕ, зокрема Стаття 11 присвячена ємностям, виготовленим із пластмасових композитних матеріалів, Стаття 12 - металевим ємностям, які гідростатично перевіряють iз застосуванням методу АЕ, Стаття 13 - безперервному AЕ-моніторингу ємностей та Стаття 29 - стандартам ASTM та іншим нормативним документам, в яких сформульовано методологічні принципи і процедури, що стосуються випробувань за допомогою методу АЕ. Слід зазначити, що $\mathrm{AE}$ - єдиний метод НК, рекомендований до безперервного моніторингу цілісності відповідального обладнання.

Оскільки діючі ядерні енергоблоки не передбачали використання АЕ-контролю чи моніторингу, то для ядерної енергетики ці статті означали не стільки впровадження методу АЕ на діючих, скільки перспективність використання AЕ-діагностування на нових енергоблоках. Стаття 12 унормовувала законність використання методу $\mathrm{AE}$ на етапі гідростатичних випробувань обладнання першого контуру перед уведенням енергоблоку в експлуатацію, а Стаття 13 унормовувала онлайн-моніторинг обладнання діючого реактора. При цьому встановлено процедури перевірки кваліфікації персоналу, що відповідає за АЕ-обстеження, а також об'єм АЕ-контролю, його тривалість, критерії оцінювання та ранжування, а також спосіб документації виявлених дефектів. Виконання всіх процедур AЕ-контролю повинно відповідати технічним стандартам, розробленим переважною більшістю у ASTM [11].

Стаття 13, зокрема, приділяє немало уваги первинним перетворювачам АЕ, дозволяючи використання як перетворювачів прямого контакту, так і з хвилеводами. Розташовувати перетворювачі на досліджуваному об' єкті контролю слід таким чином, щоб забезпечити належний рівень сигналу від дефектів-джерел АЕ та належну точність для виявлення місця знаходження дефекту. Вибраний первинний перетворювач - низько- чи високотемпературний, радіаційно стійкий чи нестійкий - має відповідати своєму призначенню. Рівень наведених електромагнітних шумів на ділянці «первинний перетворювач-попередній підсилювач-з'єднувальні кабелі» не повинен перевищувати 0,7 В за 90 дБ підсилення. Спектральні характеристики AЕ-перетворювачів повинні бути оптимально підібраними стосовно співвідношення «сигнал-шум» та згасання сигналу АE. Рекомендується використання диференційних первинних перетворювачів, призначених для відстежування наведених електромагнітних сигналів 
та індуктивно налаштованих, для яких спектральні характеристики модифіковані задля посилення чутливості у певній ділянці спектру. Для передачі AЕ-даних до АЕ-системи потрібно використовувати коаксіальні кабелі. Крім того, серйозну увагу необхідно звернути на місця проходження комунікацій через герметичну оболонку реактора. Після FT-випробувань на AEC Limerick стало зрозуміло, що у майбутніх проектах ядерних енергоблоків слід передбачити належну систему кабелів, які проходять через герметичну оболонку. Вони повинні гарантувати мінімальні втрати та мінімальне наведення електромагнітних шумів на всій ділянці передавання АЕ-даних [11].

Система обробки та реєстрування АЕ-даних повинна містити наступні модулі для кожного каналу: підсилення; ідентифікування сигналу та опрацювання сигналу. Вона має бути обладнаною відеодисплеєм для проглядання зареєстрованих АЕ-сигналів під час експлуатування, а також надійну систему зберігання АЕ-даних. Система аналізу даних може бути інтегрована у функцію дисплея або працювати в режимі пост-обробки записаних АЕ-даних. Система онлайн-моніторингу повинна бути здатною обробляти та записувати AЕ-дані зі швидкістю не менше, ніж 50 імпульсів за секунду одночасно для всіх каналів, в режимі безперервного моніторингу та зі швидкістю не менше, ніж 100 імпульсів за секунду одночасно для всіх каналів, в режимі довільних 15-секундних інтервалів [11].

Система AE-моніторингу повинна в режимі реального часу розрізняти сигнали $\mathrm{AE}$, викликані ростом тріщини, від сигналів АЕ, породжених іншими причинами, причому жоден сигнал, що перевищує поріг дискримінації, не повинен пропасти. Динамічний діапазон процесора сигналу повинен бути щонайменше 36 дБ для кожного вимірюваного параметра, причому процесор повинен управлятися модулем дискримінації, який обмежує кількість АЕ-сигналів тільки до тих, які перевищують рівень дискримінації. Останній визначається рівнем шумів [11].

Серед параметрів сигналів AE, які повинні відстежувати система AЕ-моніторингу: сумарний рахунок імпульсів, сумарний рахунок імпульсів на кожному первинному перетворювачі, амплітуда пікового імпульсу сигналу, час наростання амплітуди, площа огинаючої (виміряна у В·с), диференційні часи приходу сигналу. На додаток до перелічених, система повинна для кожного сигналу фіксувати реальні час і дату, а також параметри енергоблоку, які можуть впливати на ріст тріщини (тиск, температура тощо), та діюче значення шумів для кожного каналу з метою відстежування витоків через наскрізні дефекти першого контуру. Коли швидкість рахунку від групи первинних перетворювачів перевищить задану межу, система AE-моніторингу повинна включати блок оповіщення оператора із зазначенням розташування групи перетворювачів, які виявили надміру активне джерело АЕ [11].

Стаття 13 описує вимоги до всіх складових системи АЕ-моніторингу, до методів їх верифікації, включно із засадами встановлення первинних перетворювачів, їх калібрування, перевірки системи локації, встановлення кабелів, АЕ-монітору тощо. Зазначимо, що Стаття 13 і визначає специфічні вимоги до системи АЕ-моніторингу обладнання ядерного енергоблоку. Наприклад, власні шуми попереднього підсилювача не повинні перевищувати 7 мкВ у перерахунку до його входу (хвильовий опір 50 Ом). Спектральні характеристики попереднього підсилювача мають відповідати первинним перетворювачам. Динамічний діапазон AЕ-системи із відключеними первинними перетворювачами потрібно перевіряти за допомогою генератора сигналів ще перед встановленням на об'єкті контролю. Пакети синусоїдальних сигналів від генератора подають на входи кожного 3 попередніх підсилювачів для перевірки відповідності коефіцієнтів підсилення, функцій опрацювання АЕ-даних, швидкості опрацювання інформації тощо. Рівень сигналу від генератора повинен знаходитися в межах 0,25...5,0 мВ (амплітудне значення), тривалість пакетів - 0,5 і 3,0 мс, частота - 100 кГц і 1 МГц [11].

Первинні АЕ-перетворювачі повинні витримувати робоче середовище - температуру, вологість, вібрації, радіаційне опромінення - впродовж не менше, ніж 2 роки. В області гарячої зони реактора допустимо використовувати первинні перетворювачі, оснащені хвилеводами, достатньо довгими, щоб винести п'єзокерамічний елемент та електронні компоненти попереднього підсилювача поза зону інтенсивного опромінення. Частотні характеристики АЕ-сигналу на виході попереднього підсилювача повинні бути такими, щоб мінімізувати вплив акустичних шумів, які виникають внаслідок протікання теплоносія. Спектральні характеристики шумів у точках майбутнього AE-моніторингу необхідно отримувати ще перед встановленням первинних АЕ-перетворювачів. На підставі цієї інформації підбирають відповідні спектральні характеристики останніх, причому крутизна спаду нижче вибраної частоти моніторингу повинна становити щонайменше 15 дБ на 100 кГц. Це досягається використанням індуктивності між п’єзоелементом і входом попереднього підсилювача. Зріз верхньої ділянки спектру повинен починатися від 1 МГц із крутизною спаду не менше, ніж 15 дБ на октаву. Ці вимірювання виконуються з використанням широкосмугового джерела акустичного шуму, отриманого під час 
обдування поверхні калібрувального металевого блоку гелієвим струменем із сопла. Порогові значення для всіх каналів встановлюють на одному рівні: 0,5-1,0 В вище рівня шумів вимірювальних АЕ-каналів [11].

Стаття 13 також визначає аналітичний вираз для апроксимації залежності швидкості $d N / d t$ росту тріщини від швидкості рахунку АE-імпульсів. Представлена у англійській системі мір, ця залежність виглядає так:

$$
d a / d t=290(d N / d t)^{0,53}
$$

якщо $d a / d t$ виражена у мікродюймах за секунду. Це відповідає

$$
d a / d t=7,37(d N / d t)^{0,53},
$$

якщо $d a / d t$ виражена у мкм/с [11].

Якщо за аналізом АЕ-даних тріщина розвивається швидше, ніж це дозволяють критерії прийняття (acceptance criteria), ту ділянку металу, де було виявлено ріст тріщини, слід обстежити іншими методами НК за найближчої нагоди. Крім того, існують додаткові норми використання АЕ-моніторингу так званих обмежених зон за наступних умов:

- моніторинг ділянок металу, де були виявлені тріщиноподібні дефекти;

- моніторинг певних зварних з'єднань;

- моніторинг ділянок, чутливих до руйнування (втома, корозія тощо);

- покращення співвідношення «сигнал-шум».

Додатковою вимогою до таких систем локального моніторингу є реєстрація щонайменше $90 \%$ АЕ-сигналів, що виникають у обстежуваній ділянці та ігнорування щонайменше 90 \% сигналів, що надходять 3-поза неї [11].

Спеціальної уваги надано в Статті 13 питанню використання АЕ-обладнання в умовах агресивного зовнішнього середовища. Зокрема, більшість первинних АЕ-перетворювачів не передбачені для роботи за температур, вищих від $150{ }^{\circ} \mathrm{C}$. Деякі перетворювачі, які виготовлені для високотемпературних вимірювань, не можуть працювати тривалий час. Додатковий вплив агресивного середовища i/чи радіаційного опромінення призведе до подальшого скорочення терміну життєздатності такого АЕ-перетворювача. Для вирішення цієї проблеми Стаття 13 пропонує застосовувати хвилевідні первинні перетворювачі, розроблені групою Гаттона для моніторингу головного циркуляційного трубопроводу AEC Limerick [12]. Такого типу хвилевідні АЕ-перетворювачі були успішно апробовані впродовж навіть 2,5 років безперервної роботи в умовах високих температур і радіації. Для хвилевода діаметром 3,3 мм, виконаного 3 корозійностійкої сталі типу AISI 308, коефіцієнт згасання хвиль АЕ становить 0,45 дБ на кожний фут довжини, тобто 1,5 дБ/м [11].
Нормованим у Статті 13 є також застосування AЕ для виявлення витоків теплоносія. Перевагою AЕ-моніторингу є швидкість виявлення витоку та здатність його кількісної оцінки. Для цієї мети використовують первинні перетворювачі з певними спектральними характеристиками: за наявності високочастотних шумів робоча смуга перетворювача може бути обмеженою 200...500 кГц, тоді як в умовах низькочастотного шуму допустимо використовувати перетворювачі 3 частотами нижче 100 кГц. Кількісні залежності інтенсивності АЕ сигналу від швидкості витоку встановлюють у лабораторних умовах ще перед встановленням системи моніторингу на об'єкт контролю. Первинні перстворювачі АЕ обладнані хвилеводами діаметром 3..13 мм та довжиною не більшою, ніж 250 мм, добре себе зарекомендували для виконання поставленого завдання. Для належно встановленої системи AЕ-моніторингу вважають, що перевищення діючого значення напруги АЕ-сигналу над шумом щонайменше на 3 дБ впродовж щонайменше 30 хв свідчить про витік. Місцезнаходження витоку встановлюють за аналізом зміни діючих значень напруги сигналів від встановлених первинних перетворювачів [11].

Стаття 13 розділу V наводить ще низку вимог до запровадження AE-моніторингу на обладнанні ядерного енергоблоку. Одночасно, в додадку 2000 р. до Кодексу ASME редакції 1998 р. у розділі XI, що стосується правил контролю обладнання АЕC, вміщено статтю IWA-2234 Acoustic Emission Examination [13]. У ній зазначено, що АЕ-контроль може бути використаний для моніторингу тріщиноподібного дефекту, виявленого іншими методами НК. Перед початком AЕ-моніторингу розмір дефекту має бути встановленим за допомогою ультразвукового діагностування відповідно до інших нормативних документів ASME. AE-моніторинг слід здійснювати згідно з вимогими Статті 13 розділу V із наступними додатковими вимогами щодо розбивання процесу моніторингу на двомісячні періоди та прогностичних розрахунків розміру тріщини на моменти закінчення цих періодів із відстеженням критичності розміру тріщиноподібного дефекту та критеріїв його прийняття, сформульованим у статтях IWB-3600 чи IWC-3600. Якщо ж росту тріщини не фіксується впродовж операційного циклу, оператор може повернутися до типових процедур експлуатування відповідно до Статей IWB-3130 чи IWC-2410 [11].

Стаття IWB-3600 стосується аналітичного оцінювання критичності тріщиноподібних дефектів в обладнанні Класу 1, тобто першого контуру. Стосовно корпусу ядерного реактора ці вимоги прописані у частині IWB-3610, яка присвячена компонентам товщиною понад $10 \mathrm{~cm}$, виготовленим із феритної сталі. При цьому тріщини в аустенітній наплавці не потребують оцінювання, тоді як трі- 
щини, які пронизують наплавку наскрізь і врізаються у феритну основу корпусу реактора, підлягають оцінюванню, як і всі інші тріщиноподібні дефекти, що порушують цілісність феритної складової корпусу реактора. До критеріїв прийняття, за якими дозволяється експлуатування об'єкту 3 наявною тріщиною, відносять: критерій розміру тріщини (IWB-3611); критерій коефіцієнта інтенсивності напружень (IWB-3612); критерій коефіцієнта інтенсивності напружень за умов, що температура перевищує $T_{\mathrm{NDT}}+60^{\circ} \mathrm{F}$ (IWB-3613) [11].

Стаття IWB-3130 стосується процедур періодичного об'ємного та поверхневого контролю обладнання Класу 1, тобто першого контуру. Зокрема, у частині IWB-3132 ідеться про умови прийняття обладнання, які встановлюються за результатами контролю (IWB-3132.1), або внаслідок заміни чи ремонту пошкодженого компоненту (IWB-3132.2), або внаслідок аналітичних розрахунків, які, якщо здійснені згідно з встановленими процедурами, переконливо показують, що обладнання може безпечно працювати 3 дефектом, хоч його розміри за результатами НК і перевищують допустимі [11].

У цих же Додатках 2000 р. до Кодексу ASME редакції 1998 р. нормується застосування методу AE на обладнанні Класу 2, як це зроблено у частині IWC-2420, вимоги якої суттєво перегукуються iз вимогами, описаними вище [13].

Таким чином, метод АЕ посів належне місце у Кодексі ASME, який відіграє роль основоположної нормативної бази для країн-користувачів ядерної енергії та міжнародних контролюючих організацій, таких як IAEA. Відстежуючи зміни у питанні застосування методу АE на АEC, можна зауважити, що у 13-й редакції регламенту U.S. NRC Regulatory Guide 1.147 Inservice Inspection Code Case Acceptability ASME Section XI, виданого 2003 р., знову знаходимо статтю N-471, до якої у 1998 р. ASME уведено поправки [14]. Ця норма Кодексу ASME востаннє була перезатверджена у 2002 р. в ASME і у 2007 pp. у NRC [15, 16]. У 2002 р. ASME цю статтю анулює, як зазначено у 16-й редакції документу 1.147 NRC [17]. Вилучення статті N-471 зі збірника прикладів застосування різних методів НК Inspection Code Case Acceptability, однак, не означало вилучення методу АЕ з Кодексу ASME. В редакції 2004 p. відповідні статті розділів V і XI зберігаються i їх використовують провідні фірми-виробники обладнання для АЕC, як, наприклад, французька AREVA. Зауважимо, що Кодекс ASME або просто перекладений 3 англійської мови на мови країн ядерного клубу, або із незначними змінами адаптований до діючих у цих державах нормативів. Наприклад, нормативні документи Франції теж передбачають можливість (не обов'яз- ковість) застосування методу АЕ на корпусах діючих реакторів АЕС.

Незважаючи на тимчасове згасання активності АЕ-контролю корпусів ядених реакторів, можна сподіватися, що розвиток електроніки, матеріалознавства та механіки руйнування відкриють нові надії на успішне використання методу АЕ у майбутньому [18].

Перспективи використання АЕ для контролю руйнування корпусних реакторних сталей. Останніми роками спостерігаємо посилення активності довкола ядерної енергетики, спричиненої, з одного боку, потребою продовження терміну експлуатування 436 реакторів та, 3 іншого, перспективами понад 60 енергоблоків, що знаходяться у стані спорудження, а також понад 160 (станом на 2011 р.) реакторів, спорудження яких обговорюється. І хоча катастрофічна аварія на АЕС Фукусіма-1 в Японії завдала серйозного удару по репутації атомної енергетики, АЕC i далі залишаються одним із головних претендентів на задоволення зростаючих енергетичних потреб людства [19]. У США, наприклад, можна виділити три головні напрями такої активності:

- продовження ліцензій діючих реакторів на легкій воді;

- створення оновлених версій легководяних реакторів - так званих Generation III+ (Gen III+);

- розроблення нових типів реакторів - так званих Generation IV (Gen IV) - із використанням системи пасивної безпеки [20]. До них відносять і малі модульні реактори (small modular reactors - SMR).

Світова ядерна енергетика підлягає найсуворішим вимогам нормативних документів як національних, так і міжнародних органів. Це стосується, в тому числі, і засобів технічного діагностування, що охоплюють теоретичні, інструментальні та методологічні аспекти. У США значна частина із 104 діючих ядерних реакторів, тривалість ліцензій у яких становить 40 років, постала перед завданням продовження ліцензій на наступних 20 років, після чого можуть вдатися і до продовження терміну дії енергоблоків до 80 років. Першим етапом продовження такої ліцензії $€$ розгорнуті дослідження рівня і механізмів старіння матеріалів головних елементів обладнання, виявлення і знешкодження усіх небезпечних дефектів у елементах конструкцій чи обладнанні.

Впродовж років виявилося, що старіння конструкційних матеріалів $є$ важливим чинником безпеки, і якщо окремі елементи конструкцій чи обладнання, які частково втратили свої функціональні властивості, можна замінити на інші, то замінити корпус ядерного реактора, чи, наприклад, трубопроводи першого контуру, неможливо. Тому виявлення і відстежування дефектів у такому обладнанні має виняткову вагу. Останнє ж є ділян- 
кою активного використання різних засобів НК. Підкреслимо, що методологія діагностування таких об'єктів швидко розвивається, не втрачаючи мотивацій, пов'язаних із припиненням експлуатування діючих реакторів, оскільки і на реакторах нового покоління, що тепер перебувають у стані активного розроблення, проблеми діагностування і моніторингу не відрізнятимуться суттєво від тих, що існують на діючих AEC [19].

3 огляду на це, все принципове обладнання ядерного енергоблоку поділяють на активне, себто таке, що має рухомі компоненти - помпи, клапани, та пасивне - корпус реактора, головні циркуляційні трубопроводи тощо. Для контролю стану діючого (старіючого) пасивного обладнання у США розроблено і впроваджено «Плани контролю старіння» (Aging Management Plans) i «Регламентований контроль» (Scheduled In-Service Inspection). Вони визначають вимоги до НК, включно з переліком методів діагностування, періодичності, кваліфікаційних процедур тощо. При цьому ці документи безпосередньо пов'язані з Кодексом ASME, який був і залишається основоположним для операторів ядерних реакторів [17, 19, 21].

Діючі ядерні енергоблоки спроектовано так, що НК корпусів реакторів під час їхнього експлуатування не передбачався. Нормативні вимоги до такого контролю з'явились, коли АЕС вже були введені в роботу, а тому НК їх окремих елементів був і залишається утрудненим, а то і неможливим. Однак для майбутніх реакторів, що сьогодні проходять стадію проектування, тобто для реакторів Gen III+ та Gen IV, передбачається впровадження сучасних систем AE-моніторингу. AE-дані, накопичені такими системами впродовж експлуатації реактора, увійдуть у банк даних, на основі якого робитимуть висновки про залишковий ресурс та безпеку роботи енергоблоку.

Сьогодні спеціалісти щораз більше віддають перевагу такому підходу до обслуговування ядерних реакторів, коли поточні ремонти роблять не періодично згідно з планом, а за потребою відповідно до ступеня погіршення його стану (для активного обладнання) чи на основі даних автоматизованого моніторингу (для пасивного). На AEC нового покоління головними складовими систем виявлення та відстежування дефектності матеріалів реакторного обладнання будуть: методи НК та аналізу для виявлення деградованого чи аномального стану металу; алгоритми кількісного оцінювання рівня деградування елементів обладнання та алгоритми для розрахунку залишкового ресурсу цих елементів [19]. До методів НК пасивного обладнання, які сьогодні є регламентовані відповідними нормативними документами, належать: радіографічні, ультразвукові, візуальні, електромагнітні та теплові. За винят- ком візуального контролю всі ці методи призначені для виявлення дефектів матеріалу шляхом локального впливу на нього певним збудником енергії. Вони вимагають проведення суцільного обстеження цілої деталі, що у випадку корпусу ядерного реактора $\epsilon$ надзвичайно затратним процесом. Вигідно в цьому сенсі відрізняється метод $\mathrm{AE}$, що планується для моніторингу пасивного обладнання, оскільки з його допомогою можна кількісно оцінювати тріщиноутворення, витік теплоносія та відстежувати наявність незакріплених елементів [22-26].

Стосовно класифікації, то переважну більшість діючих ядерних реакторів відносять до Generation II (Gen II). До цієї генерації належать і реактори типу ВВЕР, що працюють в Україні [27]. Вдосконалення другої генерації реакторів шляхом покращення технології палива, теплової ефективності, системи пасивної безпеки і стандартизованого дизайну окремих елементів можуть вивести реактори на рівень третього покоління Gen III. Нещодавно збудовані енергоблоки, як, наприклад, ABWR - Advanced Boiling Water Reactor в Японії, теж належать до Gen III. Прикладами реакторів Gen III+, у яких покращені показники безпеки та ефективності роботи, $є$ European Pressurized Reactor EPR типу AP-1000 та Economic Simplified Boiling Water Reactor - ESBWR. Енергоблоки EPR споруджуються тепер у Фінляндії, Франції та Китаї. Корпуси таких реакторів обладнають системою безперервного моніторингу в режимі реального часу, як, наприклад, на реакторі EPR Олкілуото у Фінляндії, де встановлено 256-канальну систему моніторингу [19].

Оцінка ступеня зрілості діагностичних та прогностичних технологій для АЕС наступного покоління виявила, що для пасивних компонентів (до них належать і корпуси ядерних реакторів) діагностичні технології знаходяться в процесі розробки, а прогностичних ще немає [28, 29]. Частково це пов'язано з тим, що конструкції реакторів нового покоління - Gen IV - можуть суттєво відрізнятися від існуючих. Наприклад, Міністерство енергетики США серед запропонованих проектів вибрало конструкцію реактора 3 надвисокою температурою енергоносія - так званого Very High Temperature Reactor - VHTR (реактор надвисокої температури), призначеного для виробництва як електроенергії, так і водню. Регульований графітом і охолоджений гелієм, 3 гранульованим паливом низькозбагаченого урану, такий реактор мав би високу термодинамічну ефективність та проектний ресурс 60 років. Для виготовлення його корпусу використовуватимуть сталі вищого рівня міцності порівняно з традиційними (SA508/SA533 та 2-1/4Cr-1Mo) і передбачають застосування керамічних та композитних матеріалів на внутріш- 
ній поверхні корпусу, оскільки температура теплоносія може перевищувати $800{ }^{\circ} \mathrm{C}$, досягаючи $1050{ }^{\circ} \mathrm{C}[30]$.

Для забезпечення належної роботи такого реактора мусить бути створена новітня система діагностування як для етапу його виготовлення, так і для періоду експлуатування. Серед існуючого спектру методів НК, які розглядаються як пріоритетні, виділяють акустичні, зокрема акустико-емісійний [30]. Можна сподіватися, що із прискорюючим поступом у мікроелектроніці та комп'ютерних технологіях метод АЕ може ставати щораз привабливішим. Громіздкі системи $\mathrm{AE}$ та величезні масиви AЕ-даних, які створювали суттєві перешкоди для впровадження цього методу, перестають бути проблемами з мініатюризацією та суттєвим збільшенням швидкості обробки інформації. Більше того, стрімко розвиваються безпровідні системи передачі даних, які витіснять протяжні дротяні мережі, що з'єднують первинні перетворювачі з системами аналізу, опрацювання і зберігання даних контролю. Не виключено, що і оптичні безконтактні АЕ-перетворювачі також можуть знайти своє застосування, особливо для моніторингу важкодоступних ділянок корпусу реатора.

Останнім часом значно підвищився інтерес до автоматизованих алгоритмів аналізу даних, отриманих із систем неруйнівного контролю пасивних компонентів АЕС, наприклад, систем вихрострумового моніторингу [31, 32]. Для виявлення дефектів у пасивних компонентах застосовують кілька різних емпіричних підходів. Типовим є попереднє підсилення сигналу та його фільтрування задля зменшення впливу неінформативного шуму та підвищення співвідношення «сигнал/шум». Така процедура зменшує загальну кількість сигналів, що потребуватимуть подальшого аналізу. Після цього зазвичай йде процедура дискримінації сигналів відносно порогових значень (у шкалі часу чи частоти, чи вейвлетних параметрів), внаслідок якої виокремлюються лише корисні інформативні сигнали. Ці ж підходи, до речі, впродовж десятирічь успішно використовують під час AЕ-діагностування обладнання та конструкцій.

Одним із важливих питань, що стосується діагностування пасивних компонентів AEC, $є$ надійність методу вимірювань. Загалом, виявлення і діагностування дефектів матеріалу має імовірнісну складову, що залежить від таких чинників, як рівень шумів, мікроструктура, стан поверхні, доступ, людський чинник тощо. В ядерній енергетиці питання надійності методів НК нормовані у розділі XI, додатку VIII Кодексу ASME [17, 19, 21], де визначено відповідні методи, методики та кваліфікації персоналу. Використання автоматизованих алгоритмів для виявлення та оцінювання дефектів металу ускладнює процедуру розрахунку надійності того чи іншого методу НК. Однак, без огляду на те, чи використовують автоматизовані алгоритми чи ні, імовірність виявлення дефекту в матеpiaлi (probability of detection - POD) мусить бути задана для подальшого прогностичного аналізу залишкового ресурсу обладнання. 3 іншого боку імовірність невиявлення дефекту використовують для встановлення ефективності системи чи програми моніторингу обладнання [19].

Ключовим елементом довготривалого експлуатування AEC є управління процесами старіння матеріалів обладнання пасивного типу, до якого відносяться і корпуси ядерних реакторів. Відповідно до Кодексу ASME, станом на сьогодні, для періодичного НК обладнання та елементів конструкцій АЕС можна використовувати електромагнітні, ультразвукові, радіографічний та візуальний методи. На відміну від перерахованих, метод AЕ-моніторингу - єдиний, згідно з Кодексом ASME, який санкціонований для безперервного моніторингу дефектів окремих елементів $\mathrm{AEC}$ і який можна використовувати за умови, що діагностування здійснюється іншими методами НК. Оцінювання швидкості росту тріщини слід здійснювати що два місяці, екстраполюючи розрахункові дані на момент найближчої зупинки енергоблоку, коли можна буде встановити можливість чи неможливість подальшого експлуатування цього обладнання. Крім того, згідно з правилами Кодексу ASME (стаття IWA-2234 Частини I розділу XI) кожний новий дефект, виявлений методом $\mathrm{AE}$, повинен діагностуватися іншим методом НК $[19,33]$. Оцінювання швидкості росту тріщини із застосуванням методу АЕ здійснюють на основі консервативних розрахунків, наведених у Статті 13 та додатку I розділу V Кодексу.

Кодекс ASME регламентує також вимоги до застосування методу АЕ для моніторингу витоків теплоносія. Ці вимоги виписані у Статті 13 та додатку VI розділу V Кодексу ASME. Лабораторні дослідження показали, що чутливість системи моніторингу витоку становить $0,05 \ldots 20$ мг/с в залежності від рівня шумів. Саме за допомогою такої системи було виявлено корозійну тріщину в накривці реактора на AEC Bugey у Франції. Виявлений витік теплоносія становив близько 0,05 мг/с [34].

Застосування методу АЕ може мати й опосередковану функцію. Оскільки нормованою залишилась практика використання зразків-свідків типу Шарпі для визначення ступеня окрихчування металу, використання методу АЕ для виявлення умов розвитку руйнування під час динамічного навантаження дає змогу підвищити достовірність випробувань, що має велике значення з огляду на обмежену кількість зразків-свідків та важли- 
вість висновків, які роблять із аналізу отриманих результатів. Значення $J$-інтеграл $J_{i d}$ в момент зародження тріщини під час динамічного навантаження зразка та динамічну межу плинності $\sigma_{y d}$ вважають критеріальними параметрами для визначення пружнопластичної поведінки матеріалів в умовах швидкого навантаження. Для визначення цих величин під час випробувань триточковим ударним згином важливим є виявлення факту зародження тріщини та встановлення межі плинності з кривої «ударне навантаження-деформація» відповідно. Саме для реєстрування розвитку в’язкої тріщини та для визначення початку плинності матеріалу було запропоновано використовувати метод АЕ. Під час випробувань на ударний згин АЕ-перетворювачі встановлювали на молоті маятника, а за навантаження триточковим згином iз середньою його швидкістю додаткові AЕ-перетворювачі встановлювали на поверхні зразка. Результати, отримані під час цих експериментів, показали, що за допомогою методу АЕ можна отримувати достовірні результати як для значення $\sigma_{y d}$, так і для $J_{i d}$, оскільки встановлювався момент зародження/розвитку в'язкої тріщини. Характерні сигнали АЕ, отримані при цьому, відрізнялись у залежності від процесу, який їх зумовлював [35].

Досліджують і вплив радіаційного опромінення на АЕ-перетворювачі, очевидно вивчаючи перспективи використання АЕ-контролю цілісності матеріалів, які працюють в умовах високої радіації [36].

Не зупиняється активність у цьому напрямі одного із чільних світових виробників АЕ обладнання - MISTRAS Group. В одному із своïx останніх рекламних оголошень корпорація переконує, що для контролю стану підіймальних пристроїв регулюючих/поглинаючих стрижнів системи управління і захисту реактора можна успішно використовувати метод АЕ [37]. Відповідно до нормативних вимог, зокрема рекомендацій NUREG-0612 [38] та ANSI N14.6-1978 [39], накривка корпусу і системи управління і захисту реактора повинні періодично перевірятися шляхом перевантаження та неруйнівного контролю. При цьому піднімальні пристрої мають перевірятись або шляхом 10-хвилинного 150\% перевантаження $з$ одночасним спостереженням критичних областей і зварних з'єднань на предмет деформування та утворення дефектів, або ретельною перевіркою розмірів, візуальної інспекції та НК їх головних несучих зварних з'єднань. Для проведення 150\%-ного перевантажуючого випробування такого пристрою його необхідно витягнути і перемістити поза корпус реактора, що є дороговартісною процедурою, зокрема через зупинку виробничого циклу. Ще дорожчим є розбирання підіймального пристрою на частини i їх приготування до НК 3 небезпекою пошкодження під час його повторного збирання і встановлення. Задля зменшення витрат на контроль стану системи управління і захисту реактора запровадили його АЕ-контроль. Вперше такий підхід випробували на 1-му блоці AEC Watts Bar. Після цього його запровадили у 1990 р. на 1- і 2-му блоках AEC Sequoyah у США зусиллями Науково-дослідного інституту EPRI та Tennessee Valey Authority під патронатом NRC. Відтак і на інших AEC був запроваджений аналогічний АЕ-контроль. Крім вже згаданих переваг, тут мінімізується радіаційне опромінення персоналу і відсутні витратні матеріали, що використовуються у інших методах НК і які кожного разу потрібно ретельно прибирати. Такий підхід повинен мати і чисто економічну перевагу порівняно 3 традиційними методами НК [23].

Серед публікацій останнього періоду знаходимо праці, присвячені різним АЕ-дослідженням. Наприклад, корейські вчені досліджували ефективність і технічні особливості використання АЕ-обладнання для локації та оцінювання маси незакріплених металевих об'єктів у межах першого контуру енергоблоку [40]. Система моніторингу незакріплених частин або елементів конструкції (Loose Parts Monitoring System - LPMS) $\epsilon$ однією $з$ найважливіших систем моніторингу структурної цілісності ядерних енергоблоків, оскільки незакріплені металеві частинки/деталі можуть спричинити блокування теплоносія в гарячій зоні реактора, перешкодити рухові регулюючих стрижнів-поглиначів, пошкодити головну циркуляційну помпу, спричинити пошкодження теплообмінника тощо. Система LPMS виконує три завдання: повідомляє про наявність незакріпленого об'єкта, встановлює місце його розташування та оцінює масу. Такі системи AE-моніторингу знаходять своє застосування у різних країнах світу [41].

Впродовж кількох десятирічь метод АЕ знайшов гідне місце серед інших методів НК товстостінних ємностей, що працюють під тиском у нафтопереробній та хімічній галузях. Його шлях у атомну енергетику, з огляду на значно вищий рівень нормативного регулювання, був і залишається складним. За більш ніж півсторіччя зусиль щодо впровадження методу АЕ можна відзначити певні успіхи, однак говорити про його нормативне обов' язкове впровадження для відстежування руйнування корпусів ядерних реакторів сьогодні не можна. Все ж спроби надати цьому методу ширші повноваження не зупиняються, особливо 3 огляду на його значний розвиток, зокрема інструментальної частини, що включає як первинні перетворювачі, так і системи опрацювання, реєстрації та обчислювально-інформаційні системи аналізу сигналів АЕ. 
Постоянное обновление нормативной базы диагностирования происходит на фоне нескольких конкурирующих тенденщий. С одной сторонь имеем нарастающую обеспокоенность старением действующего энергогенерирующего оборудования, ресурс которого неуклонно приближается к своему проектному окончанию, а с другой - две катастрофы, не связанные с таким старением. Катастрофа 1986 г. на Чернобыльской АЭС произошла из-за существенных недостатков конструкции и ненормативных действий обслуживающего персонала, а в 2011 г. на японской АЭС Фукусима - вследствие естественного катаклизма, в котором объединились землетрясение и иунами внепроектных уровней опасности. И хотя упомянутые катастрофы нанесли ощутимый удар по репутации атомной энергетики, АЭС продолжают оставаться одним из главных претендентов на удовлетворение растущих энергетических потребностей человечества. Современные тенденции разработки методов диагностирования состояния ядерного энергетического оборудования, требуют развития имеющейся и создание новой нормативной базы для их успешного применения.

1. Regulatory control of nuclear power plants. Part A(Textbook) / IAEA Training Course Series № 15. - Vienna: International Atomic Energy Agency, 2002. - 448 p.

2. Safety of nuclear power plants: Design / IAEA Safety Requirements No. NS-R-1. IAEA Safety Standards Series. - Ibid, 2000. $-73 \mathrm{p}$.

3. Hutton P. H. Acoustic emission for continuous monitoring of light-water reactor systems: a status review // Materials Evaluation. - 1988. - 46, № 2. - P. 241-246.

4. Hutton P. H., Kurtz R. J., Friesel M. A. An overview of development and application of acoustic emission methods in the United States // Nuclear Engineering and Design. - 1989. - 113. - P. 59-69.

5. Hutton P. H. Progress for on-line acoustic emission monitoring of cracks in reactor systems // Ibid. - 1987. - 98. - P. 135-140.

6. ASTM E1139 / E1139M-12 Standard practice for continuous monitoring of acoustic emission from metal pressure boundaries. - West Conshohocken: ASTM International. DOI: $10.1520 /$ E1139_E1139M-12. - 2012. - 6 p.

7. ASTM E1211 / E12 $11 M-12$ Standard practice for leak detection and location using surface-mounted acoustic emission sensors. - West Conshohocken: ASTM International. - DOI: 10.1520/E1211_E1211M-12. - 2012 $-5 \mathrm{p}$.

8. Inservice inspection code case acceptability; Regulatory guide 1.147; ASME Section XI; Division 1 / Office of Nuclear Regulatory Research, USNRC. - Washington: U.S. Nuclear Regulatory Commission. - 1994. - Revision 11. $10 \mathrm{p}$.

9. Inservice inspection code case acceptability; Regulatory guide 1.147; ASME Section XI; Division 1 / Office of Nuclear Regulatory Research, USNRC. - Washington: U.S. Nuclear Regulatory Commission, 1999. - Revision 12. $-15 \mathrm{p}$.

10. Serpan C.Z., Mayfield M.E., Muscara J.U.S. Nuclear Regulatory Commision research for primary system integrity regulations // Nuclear Engineering and Design. - 1997. 171. - P. 1-14.

11. Nondestructive examination. 2000 Addenda to Section $\mathrm{V}$ of 1998 ASME Boiler and pressure vessel code - An international code / The American Society of Mechanical Engineers. - New York, 2000. - 738 p.

12. Hutton P.H., Friesel M.A., Dawson J.F. Continuous AE crack monitoring of a dissimilar metal weldment at Limerick Unit 1 // Research Report NUREG/CR-5963, PNL-8844. Richland: Pacific Northwest Laboratory, 1993. - 91 p.

13. Rules for inservice inspection of nuclear power plant components. 2000 Addenda to Section XI of 1998 ASME Boiler and pressure vessel code - An international code / The American Society of Mechanical Engineers. - New York, 2000. $-789 \mathrm{p}$.

14. Inservice inspection code case acceptability; Regulatory guide 1.147; ASME Section XI; Division 1 / Office of Nuclear Regulatory Research, USNRC. - Washington: U.S. Nuclear Regulatory Commission, 2003. - Revision 13. - 25 p.

15. Inservice inspection code case acceptability; Regulatory guide 1.147; ASME Section XI; Division 1 / Office of Nuclear Regulatory Research, USNRC. - Washington: U.S. Nuclear Regulatory Commission, 2005. - Revision 14. - $31 \mathrm{p}$.

16. Inservice inspection code case acceptability; Regulatory guide 1.147; ASME Section XI; Division 1 / Office of Nuclear Regulatory Research, USNRC. - Washington: U.S. Nuclear Regulatory Commission, 2007. - Revision 15. - 33 p.

17. Inservice inspection code case acceptability; Regulatory guide 1.147; ASME Section XI; Division 1 / Office of Nuclear Regulatory Research, USNRC. - Washington: U.S. Nuclear Regulatory Commission. - 2010. - Revision 16. - 36 p.

18. Bond L. J. Fitness tests for old nuclear reactors - Can nuclear power stations operate safely for 80 years? // IEEE Spectrum - Inside Technology. Internet Magasine [August 2012] [Електронний Ресурс]. - Режим доступу: http://spectrum.ieee. org/energy/nuclear/fitness-tests-for-old-nuclear-reactors $/ 0 \%$ - Назва $з$ екрану.

19. Prognostics and health management in nuclear power plants: a review of technologies and applications / J.B. Coble, P. Ramuhalli, L.J. Bond et al. / Report PNNL-21515. Richland: Pacific Northwest National Laboratory, July 2012. $-124 \mathrm{p}$.

20. Abram T., Ion S. Generation-IV nuclear power: A review of the state of the science // Energy Policy. - 2008. - 36. P. 4323-4330.

21. Rules for in-service inspection of nuclear power plant components, Section XI / ASME Boiler and Pressure Vessel Code. - New York: ASME. - 2012. - 574 p.

22. Harris D. O., Dunegan H. L. Continuous monitoring of fatigue crack growth by acoustic emission techniques // Experimental Mechanics. - 1974. - 11. - P. 71-81.

23. Acoustic emission monitoring of hot functional testing: Watts Bar Unit 1 nuclear reactor / P.H. Hutton, J.F. Dawson, M.A. Friesel et al. / Research Report NUREG/CR-3693, PNL-5022. - Richland: Pacific Northwest Laboratory, 1984. - 52 p.

24. Acoustic emission of fatigue crack in pressure pipe under cyclic pressure / Q. Ai, C.-X. Liu, X.-R. Chen et al. // Nucluear Engineering and Design. - 2010. - 240. - P. 3616-3620.

25. Acoustic emission and guided wave monitoring of fatigue crack growth on a full scale pipe specimen / R.M. Meyer, S.E. Cumblidge, P. Ramuhalli et al. // Proceedings of SPIE - Health monitoring of structural and biological systems; March 6-10, 2011, San Diego, CA / Society of Photo-Optical Instrumentation Engineers. - Bellingham, 2011. - 7984. - P. 24-1-24-10.

26. On-line monitoring for improving performance of nuclear power plants - Part 2: Process and component condition monitoring and diagnostics / IAEA Nuclear Enewrgy Series No. NP-T-1.2. - Vienna: International Atomic Energy Agency. $-2008 .-69$ p.

27. ВВЕР-1000 (Остання зміна 16 вересня 2013) [Електронний ресурс] // Вікіпедія: Вільна Енциклопедія. - Режим доступу: http://uk.wikipe-dia.org/wiki/BBEP-1000 (16.09.13). - Назва з екрану.

28. Howard P. Prognostic technology - new challenges / P. Howard // Proceedings of the $59^{\text {th }}$ Machinery Failure Prevention Technology - MFPT Conference; April 1821, 2005, Virginia Beach / Society for Machinery Failure Prevention Technology. - Dayton, 2005. - P. 3-8. 
29. Improved economics of nuclear plant life management / L.J. Bond, S.R. Doctor, D.B. Jarrell, J.W.D. Bond // Proceedings of the $2^{\text {nd }}$ Intern. Symposium on Nuclear power plant life management; Oct. 15-18, 2007; Shanghai. - Vienna: International Atomic Energy Agency, 2008. - IAEA Paper IAEA-CN-155-008KS. $-26 \mathrm{p}$.

30. Next generation nuclear plant materials research and development program plan / G.O. Hayner, R.L. Bratton, R.E. Mizia, W.E. Windes / INL/EXT-06-11701. Revision 3. Idaho Falls: Idaho National Laboratory, 2006. - 220 p.

31. Automated analysis systems for characterizing eddy current SG inspection data / J. Benson, S. Ramakrishnan, S. Majumdar et al. // Proc. of the 13th Intern. Symposium on Applied electromagnetics and mechanics - ISEM2007; Sept 9-12, 2007, East Lansing. - IOS Press, 2007. - P. 157-158.

32. Automated analysis of array probe eddy current data // Report 1015125. - Palo Alto: Electric Power Research Institute, Inc., 2008. -8 p.

33. Advanced instrumentation, information, and control system technologies: nondestructive examination technologies FY11 report / R.M. Meyer, J.B. Coble, P. Ramuhalli, L.J. Bond / Report PNNL-20671. - Richland: Pacific Northwest National Laboratory, 2011. $-86 \mathrm{p}$.

34. Stress corrosion cracking in the vessel closure head penetrations of French PWRs / D. Buisine, F. Cattant, J. Champredonde et al. // Proc. of the $6^{\text {th }}$ Intern. Symposium on Environmental degradations of materials in nuclear power systems - Water Reactors; Aug. 1-5, 1993 / eds by R.E. Gold and E.P. Sdvienon. - Warrendale: MRS. - 1993. - P. 845-853.
35. Richter H., Böhmert J., Viehrig H.-W. The use of acoustic emission to determine characteristic dynamic strength and toughness properties of steel // Nuclear Engineering Design. - 1999. - 188. - P. 241-254.

36. Holbert K. E., Sankaranarayanan S., McCready S. S. Response of lead metaniobate acoustic emission sensors to gamma irradiation // IEEE Transactions of the Nuclear Society. -2005 . - 52. - P. 2583-2590.

37. Acoustic emission inspection of RPV lift \& internals to meet NUREG-0612 - Industry application / MISTRAS Group Inc., Services Division. - 2012. - 1 p.

38. Control of heavy loads at nuclear power plants. Resolution of generic technical activity A-36/U.S. Nuclear Regulatory Commission, Report NUREG-0612. - Washington: U.S. NRC, 1980. - $123 \mathrm{p}$

39. ANSI N14.6-1978 American national standard for special lifting devices for shipping containers weighing 10,000 pounds $(4500 \mathrm{~kg})$ or more for nuclear materials. Washington: American National Standards Institute, 1993. $-9 \mathrm{p}$.

40. Choi Y.-C., Park J.-H., Choi K.-S. An impact source localization technique for a nuclear power plant by using sensors of differnt types // ISA Transactions. - 2011. - $\mathbf{5 0}$. - P. 111-118.

41. Loose parts monitoring system (LPMS) // PakAtom / Newsletter of the Pakistanian Atomic Energy Commisson. 2011. - P. 4.

First acoustic-emission (AE) measuring systems of commercial modification were developed, and correlations between AE signal parameters and fracture propagation characteristics were established in the first half of the XXth century. This was exactly the basis for awakening the interest of nuclear energy technology developers and operators to this new method, which will eventually become an effective addition to the existing technologies of non-destructive testing (NDT) for detection and monitoring of nuclear reactor body defects. In view of the extremely high requirements made to such facilities in terms of their quality and integrity, significant efforts were focused on AE method development and its introduction into industry already at the end of 1970ties. Practical realization of the techniques and means for AE monitoring and diagnostics of the condition of NPP reactor bodies confirmed the high effectiveness of the method, although different opinions were expressed on this subject at the start of their introduction. 41 References.

K e y w o r d s : acoustic emission, nuclear power engineering, diagnostics normative base

\section{XIV МІЖНАРОДНА НАУКОВО-ТЕХНІЧНА КОНФЕРЕНЦІЯ «ПРИЛАДОБУДУВАННЯ: СТАН І ПЕРСПЕКТИВИ»}

22-23 квітня 2015 р. у Національному технічному університеті «Київський політехнічний інститут» (НТУУ «КПІ») відбулася ХІУ Міжнародна науково-технічна конференція «Приладобудування: стан і перспективи». Метою конференції було спілкування фахівців з питань перспективних розробок, прецизійних технологій, нових рішень у приладобудуванні, зустріч 3 керівниками провідних підприємств, формування спільних проектів, пошук партнерів для співпраці.

В роботі конференції взяли участь 242 представника 42 промислових підприємств, академічних, вузівських та галузевих дослідницьких установ 315 міст України, Іраку, Республіки Білорусь, Російської Федерації тощо.

В межах конференції на кафедрі приладів та систем неруйнівного контролю НТУУ «КПІ» працювала секція № 7 «Неруйнівний контроль, технічна та медична діагностика». В роботі секції взяли участь більше 80 фахівців у галузі неруйнівного контролю з різних міст України, що надали понад 30 доповідей. Серед учасників конференції представники: Івано-Франківського національного технічного університету нафти і газу, Харківського національного технічного університету «ХПІ»; Національного авіаційного університету, НТУУ «КПІ», Інституту проблем матералознавства НАН України, Інституту технічної теплофізики НАН України та ін.

Окрім названих гостей міста свої доповіді представили викладачі та магістранти НТУУ «КПІ», зокрема кафедри приладів та систем неруйнівного контролю, а також співробітники інших ВНЗ м. Києва.

Доповідачі у своїх виступах висвітлювали такі актуальні в наш час питання, як основні проблеми розробки акустико-емісійних вимірювальних систем, застосування алгоритмів для обробки даних приладів дефектоскопії ходової частини рухомого складу, питання індуктивних та магнітних перетворювачів та систем пошуку та контролю дефектів та багато інших проблемних питань сьогодення. Відбулась також студентська наукова конференція з питань неруйнівного контролю. Було представлено понад 30 доповідей студентами з Івано-Франківська, Львова та студентами кафедри ПСНК НТУУ «КПІ».

Пропонуємо колегам взяти участь у роботі секції № 7 «Неруйнівний контроль, технічна та медична діагностика», що працюватиме у межах XV науково-технічної конференції «Приладобудування: стан і перспективи», яка відбудеться у квітні 2016 р. (телефон оргкомітету секції: (044) 454-95-47). 


\title{
ПРЕЦИЗІЙНЕ ВИМІРЮВАННЯ ШВИДКОСТІ УЛЬТРАЗВУКОВИХ КОЛИВАНЬ ЯК МЕТОД ОЦІНКИ НАПРУЖЕНЬ ТА УТОМИ КОНСТРУКЦІЙНИХ МАТЕРІАЛІВ
}

\author{
С. М. МАєВСЬКИЙ \\ НТУУ «Київський політехнічний інститут». 03056, г. Київ, пр-т Перемоги, 37. E-mail: mail@kpi.ua
}

\begin{abstract}
Описано метод оцінювання напруженого стану і стану утоми матеріалів на основі прецизійного вимірювання швидкості розповсюдження високочастотних УЗ коливань. Вимірювання товщини об'єктів і часу запізнення коливань у них виконано шляхом визначення значення кумулятивних фазових зсувів. Розглянуто корекцію похибок вимірювання внаслідок додаткових фазових зсувів, що виникають при відбитті УЗ коливань від донної поверхні об'єктів. Бібліогр. 3 , рис. 2.
\end{abstract}

Ключ ов і слова: напружений стан матеріалів, кумулятивні фазові зсуви, дефекти структури материалів

Вважається, що основною задачею неруйнівного контролю (НК) є визначення місця знаходження та оцінка розмірів дефектів матеріалів елементів конструкцій. Дійсно, це важлива задача і на іï вирішення направлені всі основні методи НК, адже наявність дефектів структури матеріалів може свідчити про початок руйнівних процесів. Проте для конструкцій, що експлуатуються в режимі великих механічних навантажень, поява дефектів структури матеріалу, наприклад, тріщин, взагалі може бути недопустимою, бо їх швидкий ріст в умовах знакозмінних напружень матеріалу приведе до аварійного руйнування конструкції. Для матеріалів подібних конструкцій необхідні методи контролю, які могли б передбачити можливість появи дефектів і для цього має використовуватися нетрадиційний для НК параметр контрольованого матеріалу, який має опосередковано свідчити про запас його міцності.

Вивчення процесів, що відбуваються в кристалічній структурі конструкційних матеріалів в процесі багатократних знакозмінних навантажень, привели до використання такого поняття, як «утома» матеріалу, яке пояснює виникнення мікророзривів на рівні окремих кристалів [1]. Поодинокі подібні мікродефекти з еквівалентними розмірами (20...30 мкм) не впливають на міцність конструкцій і навіть не визначаються засобами неруйнівного контролю (дефектоскопами). Проте збільшення кількості подібних мікродефектів в об'ємі матеріалу конструкції робить можливим їх об'єднання і утворення тієї небезпечної тріщини, яка, маючи значний рівень напружень матеріалу на її кінцях, продовжує свій ріст, швидко ослаблюючи міцність конструкції.

Зрозуміло, що причиною появи утоми конструкційних матеріалів $€$ їх механічне напруження внаслідок направленої дії прикладених сил. На відміну від механічного напруження утома матеріалу конструкції не має векторної ознаки.
Напружений стан конструкційних матеріалів може виникати не тільки за рахунок дії зовнішніх сил. Достатні для виникнення недопустимого напруження можуть бути і внутрішні сили, породжені, наприклад, процесами термічного походження, що мають місце при порушеннях технології ливарного виробництва, технологій зварювання та закалювання.

Контроль величини механічного напруження матеріалу може виконуватися шляхом вимірювання його деформації $\Delta l$, яка в межах пружних властивостей цього матеріалу становить $\Delta l=$ $=B(P / E)$, де $B-$ база вимірювання деформації; $P$ величина механічного напруження в матеріалі; $E-$ коефіцієнт пружності матеріалу (модуль Юнга).

Допустимі напруження в матеріалі, які не порушують умови пружної деформації, в залежності від марки сталі складають $380 \ldots 1550$ МПа, тоді як модуль Юнга становить 200...210 МПа. Виходячи 3 приведених даних, реальна величина деформації конструкційних сталей при реальній довжині бази вимірювання 10 мм зосереджена в субміліметровому лінійному діапазоні - до 20 мкм для звичайних сталей та до $50 \ldots 70$ мкм - для легованих.

Не дивлячись на необхідність вимірювання таких малих лінійних величин, деформація як параметр контролю широко використовується для оцінки напруженого стану матеріалу конструкцій. Основними вимірювальними перетворювачами деформації на сьогодні $є$ тензорезистори на основі мікродроту з константану та тензорезистори, виготовлені з використанням плівкової технології. Їх перевага - простота конструкції. Але ця простота обмежує точність виконання вимірювання деформації (не краще за 1 \%) та вимагає певних ускладнень електричної схеми тракту перетворення первинної інформації. Більш чутливими і точними $(0,1 \%) \in$ індуктивні вимірювальні перетворювачі 
деформації, які, маючи дещо складнішу конструкцію, поки що не знайшли широкого застосування.

Проте контроль величини деформації, якщо не перевищений iii допустимий рівень, не може в повній мірі дати відповідь про степінь утоми матеріалу конструкції. Лише статистичний аналіз результатів вимірювання деформації з визначенням швидкості їі зростання дає можливість встановити існування деструктивного процесу руйнування міжкристалічних зв'язків матеріалу.

Відомі два беззаперечних опосередкованих метода оцінювання степені утоми конструкційних матеріалів. Перший передбачає можливість оцінювання як напруженого стану, так і утоми лише феромагнітних матеріалів - сталей, за величиною зростання коерцитивної сили. Практична реалізація подібного методу вимагає використання процесу намагнічування і перемагнічування контрольованого матеріалу, що легко виконати для зразків цих матеріалів у лабораторних умовах і $є$ проблематичним для габаритних силових конструкцій.

Другий метод, який не має подібних обмежень, використовує залежність фазової швидкості розповсюдження високочастотних ультразвукових (У3) коливань від структурних змін середовища матеріалу. Практична реалізація цього методу є не менш проблематичною, що пояснюється необхідністю забезпечення надто високої точності вимірювання допустима похибка має бути на рівні сотих часток відсотку [2]. Враховуючи, що швидкість - це довжина шляху, пройденого коливаннями, поділена на часову затримку цих коливань, маємо необхідність ще з більшою точністю визначати і лінійний параметр - довжину шляху розповсюдження коливань і час затримки коливань на цьому шляху.

Не дивлячись на зазначені застереження, ми все ж зосередилися на розвитку саме УЗ методу контролю утоми конструкційних матеріалів, враховуючи його універсальність щодо видів матеріалів, з однієї сторони, та можливість апаратурного вирішення 3 мінімальними енергетичними та матеріальними затратами, з другої.

В основі вирішення даної проблеми став запропонований нами принцип прецизійного вимірювання часової затримки УЗ коливань шляхом визначення їх фазового зсуву. Необхідна точність вимірювання часової затримки коливань частоти $f$ реалізована завдяки визначенню накопиченого ними фазового зсуву $\theta^{\circ}$, який в подальшому називатимемо кумулятивним:

$$
\tau=\frac{\theta^{\circ}}{360^{\circ} f}=\frac{N 360^{\circ}+\psi^{\circ}}{360^{\circ} f}
$$

де $\psi^{\circ}$ - виміряний фазовий зсув; $N$ - число цілих фазових циклів $360^{\circ}$ в значенні кумулятивного фазового зсуву.
Подібний метод вимірювання часової затримки забезпечує точність, яка недосяжна для широко використовуваного в НК методу прямого вимірювання часу запізнення УЗ сигналу внаслідок похибки реального порогу чутливості амплітудного компаратора при визначенні моменту приходу луносигналу. Точність опосередкованого методу вимірювання часової затримки УЗ сигналу сягає 0,01\% навіть при похибці вимірювання фазових зсувів, рівній $\pm 1^{\circ}$, якщо стабільність частоти коливань менша $0,01 \%$, а значення $N \geq 20$, що і те, i друге легко реалізується.

Для визначення цілого числа фазових циклів у значенні кумулятивного фазового зсуву виконуємо вимірювання фазових зсувів сигналів на двох близьких частотах $f,(f+\Delta f)$, вибраних так, щоб фазові зсуви сигналів цих частот $\varphi^{\circ}$ i $\gamma^{\circ}$ гарантовано різнилися на величину меншу за $360^{\circ}$. Цієї умови досить просто досягти, використовуючи як генератор - синтезатор частоти, контролюючи значення фазового зсуву в процесі зміни частоти сигналів (рис. 1).

Враховуючи, що для УЗ частот сигналів необхідний приріст частоти $\Delta f<<f$, дисперсією швидкості розповсюдження ультразвуку в реальному середовищі при зміні частоти від $f$ до $(f+\Delta f)$ можемо знехтувати. Тоді справедливими будуть наступні рівняння [3]:

$$
\begin{aligned}
\tau & =\frac{N 360^{\circ}+\varphi^{\circ}}{360^{\circ} f} \\
\tau & =\frac{N 360^{\circ}+\gamma^{\circ}-180^{\circ}\left[\operatorname{sgn}\left(\gamma^{\circ}-\varphi^{\circ}\right)-1\right]}{360^{\circ}(f+\Delta f)} .
\end{aligned}
$$

Прирівнюючи праві частини рівнянь (2), знаходимо значення числа $N$ як найбільш наближеного цілого:

$$
N=\left[\frac{\left\{\gamma-180^{\circ}\left[\operatorname{sgn}\left(\gamma^{\circ}-\varphi^{\circ}\right)-1\right]\right\} f-\varphi^{\circ}(f+\Delta f)}{360^{\circ} \Delta f}\right]^{+}
$$

Певною особливістю вимірювань фазових зсувів УЗ сигналів є те, що з метою уникнення впливу ревекберацій ці сигнали мають бути радіоім-

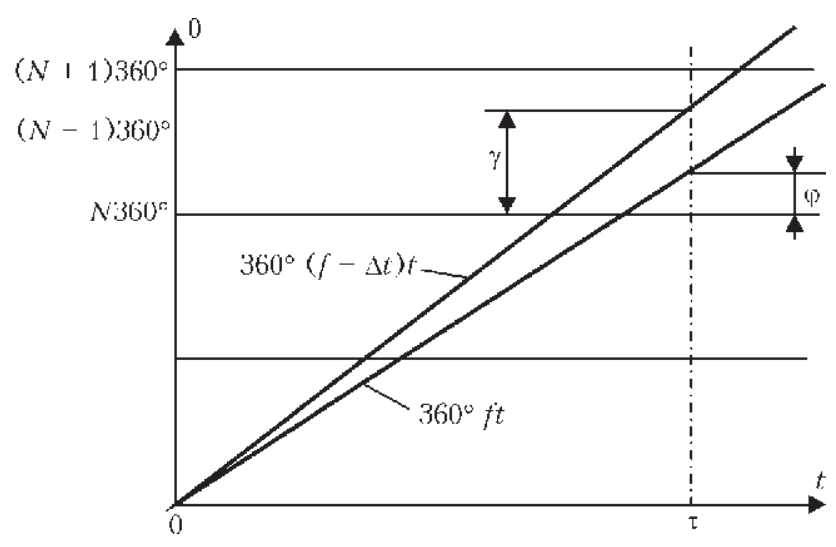

Puc. 1. Фазовий метод визначення часових затримок Уз сигналів 
пульсними. Проте тривалість цих радіоімпульсів в нашому випадку може бути достатньо великою, але не більшою за часову затримку прийнятого перетворювачем УЗ луносигналу. Для можливості вимірювання фазового зсуву УЗ коливань, які не перекриваються у часі, радіоімпульс необхідної часової довжини формується з неперервних коливань сигналу задаючого генератора за допомогою комутації. Тоді фазовий зсув коливань луносигналу, прийнятого після проходження ним середовища об'єкта контролю, вимірюється відносно опорної фази сигналу генератора. Даний спосіб визначення часової затримки може застосовуватися для всіх типів УЗ коливань.

Не аналізуючи можливі способи вимірювання фазових зсувів радіоімпульсних коливань, зупинимося на використанні найбільш простого і завадостійкого способу - фазового детектування парою подвійних балансних модуляторів 3 підключенням до одного 3 них як сигналу опорної фази - сигналу генератора, а до іншого - такого ж сигналу з фазою, зміненою на $90^{\circ}$, що дозволяє визначити фазовий зсув коливань прийнятого п'єзоперетворювачем радіоімпульсного сигналу як $\psi==\operatorname{arctg}\left(U_{1} / U_{2}\right)$, де $U_{1}, U_{2}-$ величини напруг на виходах фазових детекторів.

При нормальному вводі коливань в середовище плоскопаралельного зразка (елемента конструкції) його товщина може бути визначена також через часову затримку коливань. Розглянемо схему вимірювання, показану на рис. 2. Збудження коливань в середовищі об'єкта контролю виконуємо за допомогою п'єзоелектричного перетворювача 3 дещо розширеною головною пелюсткою діаграми направленості, для чого його діаметр має бути меншим за $6 \lambda$ (тут $\lambda$ - довжина хвилі коливань у середовищі об'єкта контролю). При такому збудженні коливань можемо організувати їх прийом

на протилежному боці об'єкта автономно двома перетворювачами, виділивши таким чином окремо коливання, яке падає на протилежну сторону об'єкта перпендикулярно і під певним невеликим кутом. Такий прийом коливань можемо ефективно виконати класичним дископодібним п'єзоелектричним перетворювачем, розділивши його провідне покриття з однієї сторони перетворювача концентрично на дві одинакові за площею частини. Якщо діаметр пластини перетворювача становить $6 \lambda$, то в результаті ділення матимемо центральну частину діаметром $4,25 \lambda$ та концентричну зовнішню частину шириною $1,75 \lambda$. Відстань між центрами цих частин перетворювачів - база вимірювання $B$, становитиме $3 \lambda$.

Ультразвукові повздовжні коливання, які приймаються обома частинами приймального перетворювача, проходять різну відстань у середовищі матеріалу об'єкта контролю. Коливання, які приймаються центральною частиною, проходять відстань, рівну товщині об'єкта $H$, а периферійна частина перетворювача приймає коливання, які проходять відстань, рівну $L=\sqrt{H^{2}+B^{2}}$. Вимірюючи часові затримки $\tau_{1}, \tau_{2}$ обох цих коливань описаним вище методом:

$$
\begin{aligned}
\tau_{1} & =\frac{N_{1} 360^{\circ}+\varphi_{1}}{360^{\circ} f}, \\
\tau_{2} & =\frac{N_{2} 360^{\circ}+\varphi_{2}}{360^{\circ} f},
\end{aligned}
$$

можемо скласти наступні рівняння для визначення швидкості їх розповсюдження $C$ :

$$
\begin{gathered}
C=\frac{H}{\tau_{1}}, \\
C=\frac{\sqrt{H^{2}+B^{2}}}{\tau_{2}} .
\end{gathered}
$$

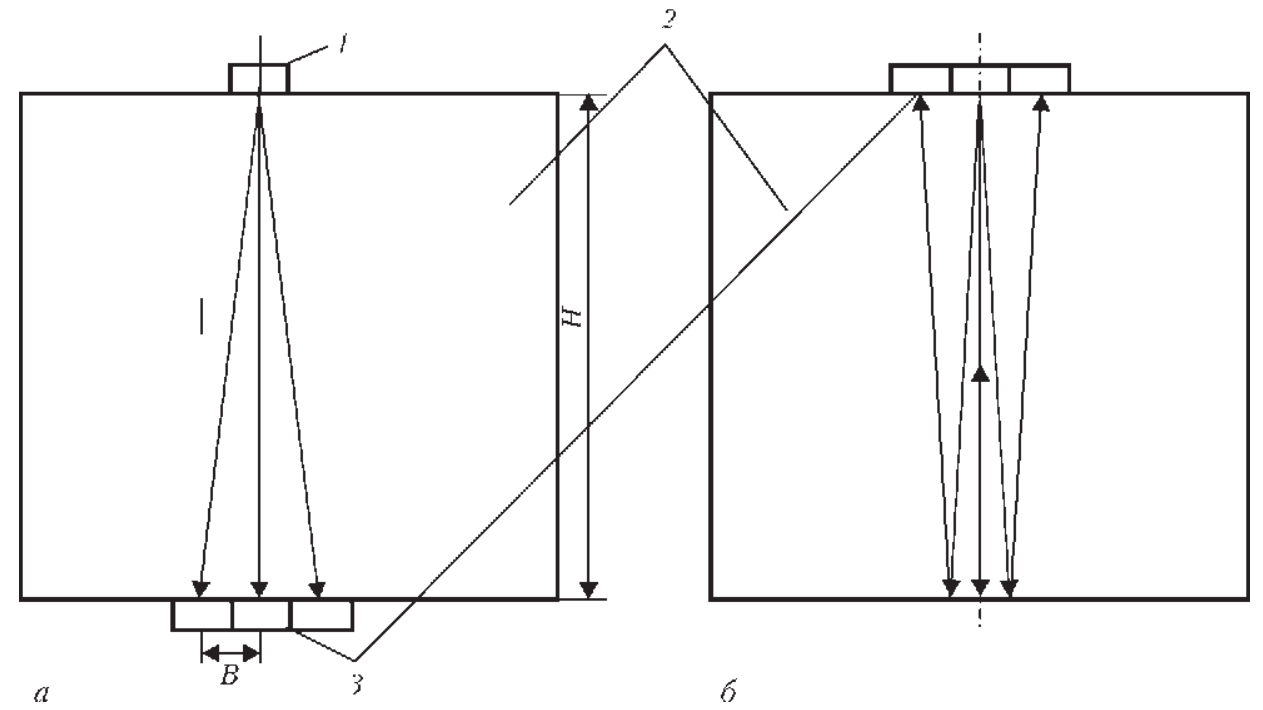

Puc. 2. Схема розповсюдження УЗ коливань у плоскопаралельному зразку: 1 - п'єзоелектричний перетворювач - збудник коливань 3 широкою діаграмою направленості; 2 - об'єкт контролю; 3 - концентрично розділений п'єзоелектричний перетворювач для прийому коливань (a) та для збудження коливань і прийому луносигналів (б) 
Прирівнюючи праві частини отриманих рівнянь, визначаємо товщину об'єкта контролю:

$$
H=\frac{\tau_{1} B}{\sqrt{\tau_{2}^{2}-\tau_{1}^{2}}} .
$$

Підставляючи значення $H$ в рівняння (6), визначаємо швидкість розповсюдження коливань:

$$
C=\frac{B}{\sqrt{\tau_{2}^{2}-\tau_{1}^{2}}} .
$$

Як бачимо, для визначення швидкості розповсюдження УЗ коливань не обов'язково знати довжину пройденого ними шляху, якщо визначені часові затримки виділених описаним чином коливань. При цьому точність визначення швидкості залежить лише від точності встановленої бази вимірювання (відстані між центрами приймальних перетворювачів) і точності визначення часових затримок (точності визначення кумулятивного фазового зсуву).

Аналогічний спосіб вимірювання можна було б реалізувати шляхом прийому подібним перетворювачем УЗ сигналів, відбитих від донної поверхні об'єкта контролю [ 3 ]. В такому випадку випромінювачем УЗ коливань і приймачем луносигналу, відбитого від донної поверхні об'єкта при нульовому куті падіння хвилі на неї, мала б бути центральна частина концентрично розділеного п'єзоелектричного перетворювача, а периферійна частина виконувала б роль приймача хвилі, відбитої від донної поверхні під кутом $\Delta \chi=\operatorname{arctg}(B / 2 H)$. Неоднакові умови відбиття УЗ коливань викликають різні значення додаткових фазових зсувів для луносигналів: для сигналу, що приймається центральною частиною - $180^{\circ}$, а для сигналу периферійної частини $180^{\circ}-2[\operatorname{arctg}(B / 2 H)]^{0}$. Ці фазові зсуви можемо оцінити величинами приросту часових затримок $\Delta \tau_{1}$, $\Delta \tau_{2}$, які відбулися за рахунок відбиття УЗ сигналів від донної поверхні об’єкта:

$$
\begin{gathered}
\Delta \tau_{1}=\frac{1}{2 f}, \\
\Delta \tau_{2}=\frac{\left\{180^{\circ}-2[\operatorname{arctg}(B / 2 H)]^{\circ}\right\}}{360^{\circ} f} .
\end{gathered}
$$

Визначені величини часових затримок є причиною виникнення адитивних похибок вимірювання товщини і швидкості розповсюдження УЗ коливань в матеріалі об'єкта. Для усунення цих похибок виконаємо корегування значень часових затримок:

$$
\begin{aligned}
\tau_{1 K} & =\tau_{1}-\Delta \tau_{1}, \\
\tau_{2 K} & =\tau_{2}-\Delta \tau_{2} .
\end{aligned}
$$

Точність корекції часової затримки $\tau_{2}$ не вимагає знання фактичної величини товщини об' єкта $H$. Як показують результати аналізу, навіть $10 \%$ неточності цієї величини не спричинять похибку подальшого визначення фактичної товщини i швидкості ультразвуку більш, як $0,01 \%$ при товщині об' єкта контролю $H>25$ мм та частоті коливань $f>5$ МГц.

Таким чином, значенням товщини і УЗ швидкості відповідатимуть вирази:

$$
\begin{gathered}
H=\frac{\tau_{1 K} B}{2 \sqrt{\tau_{2 K}^{2}-\tau_{1 K}^{2}}}, \\
C=\frac{2 H}{\tau_{1 K}}=\frac{B}{\sqrt{\tau_{2 K}^{2}-\tau_{1 K}^{2}}} .
\end{gathered}
$$

\section{Висновки}

Описаний у роботі метод прецизійного вимірювання часових затримок та швидкості УЗ коливань немає обмежень щодо типів хвиль і частоти цих коливань та середовищ їх розповсюдження. Цей метод може з успіхом використовуватися для аналогічних досліджень як твердих тіл, так і рідин та газоподібних середовищ. Визначенням часових затримок та швидкості УЗ коливань у рідких продуктах можемо вимірювати концентрацію розчинів при контролі газоподібних середовищ, наприклад, повітря, виявляти щонайменші його забруднення. Даний метод може знайти застосування при реалізації УЗ вимірювання витрат рідких та газоподібних продуктів при їх транспортуванні та при реалізації технологічних процесів.

1. Stamm H. An Overview of the Ultrasonic Detection of Creep Damage // The European J. of Non-Destructive Testing. 1992. - 1, № 4 .

2. Allan D. R., Cooper W.H.B. A Fourier Transform Technique that measuring Phase Delay between Ultrasonic Impulses with sufficient Accuracy to determine residual Stress in Metals // NDT International. - 1983. - 16, № 4.

3. Маєвський С. М. Вимірювання фазової швидкості ультразвуку як спосіб визначення напружень та утоми конструкційних матеріалів // Техн. диагностика и неразруш. контроль. -2009 . - № 3. - С. 51-55.

\footnotetext{
Method of evaluation of the stressed state and fatigue state of materials based on precision measurement of high-frequency ultrasonic vibration propagation velocity is described. Measurement of object thickness and time of vibration delay in them was performed by determination of the value of cumulative phase shifts. Correction of measurement errors resulting from additional shifts that arise at reflection of ultrasonic vibrations from the object bottom surface was considered. References 3 , Figures 2 .
} 


\title{
ПРИМЕНЕНИЕ ТЕРМОГРАФИИ ДЛЯ ОПРЕДЕЛЕНИЯ СОСТОЯНИЯ МЕТАЛЛА ТРУБОПРОВОДОВ
}

\author{
С. Н. МЕШКОВ, Р. П. ОРЕЛ \\ Харьковский нац. ун-т радиоэлектроники. 61166, г. Харьков, пр-т Ленина, 14. E-mail: fizika@kture.kharkov.ua
}

\begin{abstract}
Рассмотрены результаты термографического обследования паропроводов высокого давления и основного конденсата атомной станции. Указаны условия и методика проведения теплового контроля отдельных участков трубопроводов. Обнаружено, что кавитационные дефекты имеют «тепловой след». Предложено применение термографии как эффективного метода экспресс-контроля, который позволяет быстро определять по температурным аномалиям места для детального изучения другими методами. Библиогр. 8, рис. 5.
\end{abstract}

Ключев ве слов а: паропроводы высокого давления, термографическое обследование, термические нагрузки, кавитационные дефекть

В процессе эксплуатации конструкционные материалы, применяемые в энергетике, изменяют свои свойства, что является причиной появления дефектов, которые могут привести к техногенным авариям и катастрофам.

Высокие термические нагрузки, которые испытывает оборудование тепловых и атомных станций, ведет к снижения термического сопротивления металла, в результате чего повышается температура на поверхности оборудования и трубопроводов. Поэтому температура является важнейшим диагностическим показателем.

Применение контактных приборов не всегда возможно вследствие габаритов объекта контроля или трудностей доступа к нему. Трудоемкость обследований можно существенно снизить при применении термографии. При обследовании можно использовать те же тепловизоры, что и при строительной диагностике, однако диапазон измеряемых температур может быть расширен до $1500^{\circ} \mathrm{C}$.

При регулярном термографическом мониторинге путем сравнения результатов можно оценить состояние объекта, выявить дефектные участки и наметить пути их устранения.

В мировой атомной энергетике программы технического обслуживания АЭС предусматривают до 50 тыс. тестовых процедур, среди которых возрастает роль тепловизионного мониторинга. В США тепловизионный метод применяется на всех АЭС. Есть сведения о применении тепловизионного метода на ряде российских АЭС [1]. В отечественной энергетике тепловизионный метод пока применения не нашел.

Цель работы - определение возможности применения термографии для обнаружения скрытых дефектов металла трубопроводов с последующим детальным обследованием традиционными методами контроля.

(C) С. Н. Мешков, Р. П. Орел, 2015
Методика и условия обследования. С точки зрения проведения тепловизионной съемки трубы представляют сложный объект. Даже при равномерно нагретой трубе и ее однородном покрытии возникают эффекты, обусловленные сферичностью исследуемой поверхности [2]. Значительно усложняется и количественная оценка параметров скрытых дефектов [3, 4].

Термографическое обследование проводились на участках трубопроводов:

- без контакта с контролируемым объектом;

- без механической подготовки поверхности;

- при рабочих параметрах оборудования.

Термографирование проводили в производственных помещениях при температуре $30{ }^{\circ} \mathrm{C}$. Освещение производственных помещений соответствовало общим принципам, основным из которых является создание равномерного уровня освещенности на всей площади. Уровень освещенности учитывался как шумовая составляющая радиационной температуры и на исследуемых объектах составлял $\Delta T_{\text {зас }}=1,5 \ldots 2,0^{\circ} \mathrm{C}$.

Для лучшей привязки результатов обследования проводили фотографическую съемку обнаруженных дефектов в тех же ракурсах, что и тепловизионная съемка. Во время исследования также измеряли температуру окружающего воздуха вблизи объектов контроля.

Обследования регламентировали техническими требованиями на проведение работ «Контроль металла трубопроводов и оборудования энергоблоков методом тепловой термографии» от 02.10.2007 г.

Места тепловизионной съемки были выбраны согласно схеме, составленной по различным видам износа металла рабочего тракта ТУ К-220-44, которая являлась условной картой, полученной на основе опыта эксплуатации турбоустановок насыщенного пара. 
Обследование металла выполняли в соответствии с ПНАЭ Г-7-008-89 «Правила устройства и безопасной эксплуатации оборудования и трубопроводов атомных энергетических установок», а также на основании документации на тепловой метод контроля, результатов научных исследований и опыта роботы НТЦ «Термоконтроль».

Результаты исследований паропроводов высокого давления. Большой практический интерес представляет обнаружение скрытых дефектов в паропроводах высокого давления. Термографирование открытых участков дает положительные результаты: по характеристикам стационарного температурного поля на поверхности можно оценить величину утонения металла в месте дефекта [5]. Однако согласно действующим на тепловых станциях нормам паропроводы высокого давления покрыты рубашкой из теплоизоляции (стекловата) и помещены в защитный металлический экран. Металлические экраны имеют неровную, волнистую поверхность. Температурные градиенты такой поверхности создают на термограммах набор локальных тепловых аномалий (рис. 1).

Если поверхность достаточно гладкая, то диагностирование возможно. Признаком развивающегося внутреннего дефекта является площадь тепловой аномалии, что показано на рис. 2 .

При средней температуре поверхности экрана $T_{\text {cp. }}=49,7^{\circ} \mathrm{C}$ тепловая аномалия имеет температуру
$T_{\text {деф }}=59,6^{\circ} \mathrm{C}$, занимает значительную площадь и может являться признаком развивающегося дефекта.

При термографировании выявлен эффект «тепловой засветки» или наложения тепловых полей. Температурные поля зависят от взаимного расположения объектов теловизионной съемки, что надо учитывать при выборе ракурса при съемке.

В ходе работ было обследовано шесть фрагментов паропроводов высокого давления. Для объектов данного вида, работающих в штатном режиме, теплоизоляция сильно ослабляет и искажает температурные поля труб. Поэтому тепловизионным методом обнаруживать скрытые дефекты можно только в заключительных стадиях их развития.

Результаты исследований трубопровода основного конденсата. Гидротехническое оборудование подвержено кавитационной эрозии. Кавитационная эрозия обусловлена явлением кавитации, возникающим в движущемся потоке жидкости при определенных гидравлических условиях. Эрозионное разрушение поверхности при кавитации происходит вследствие многократно повторяющихся гидравлических ударов струй жидкости о поверхность. На рис. 3 показан фрагмент трубопровода с дефектом, обусловленным кавитационным износом.

Экспериментальные факты подтверждают, что скорость кавитационного разрушения металла в $5000 \ldots 10000$ раз превосходит скорость коррозионного разрушения. Хотя общепринятой теории

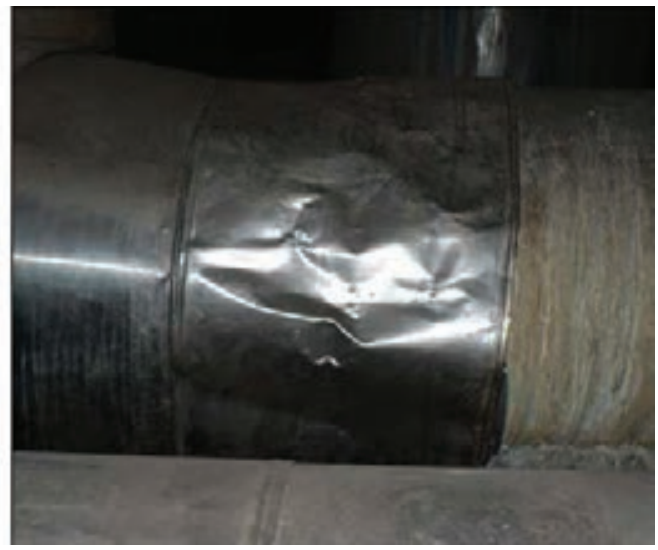

Puc. 1. Локальные тепловые аномалии, вызванные рельефом поверхности паропровода

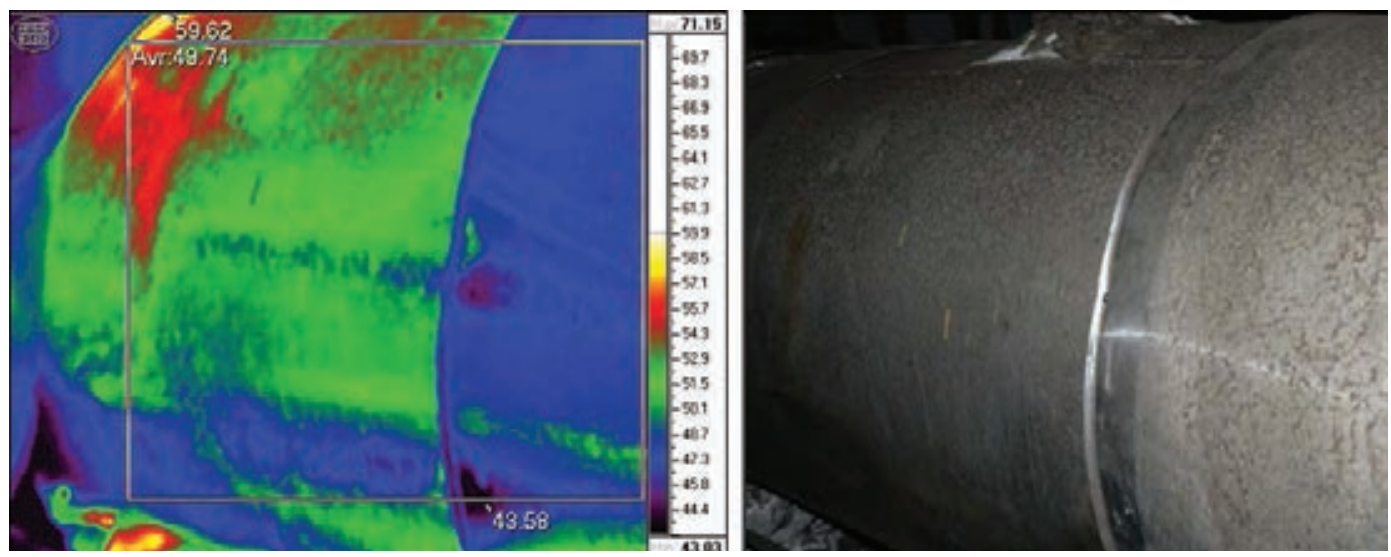

Puc. 2. Участок паропровода высокого давления с возможным развивающимся дефектом 
кавитации не существует, но по некоторым оценкам пики давлений при сжатии (или разрушении) кавитационных каверн доходят до 250 МПа, а температур до $10^{4} \mathrm{~K}$ [6-8].

Следовательно, места образования кавитационных каверн являются локализованными источ-

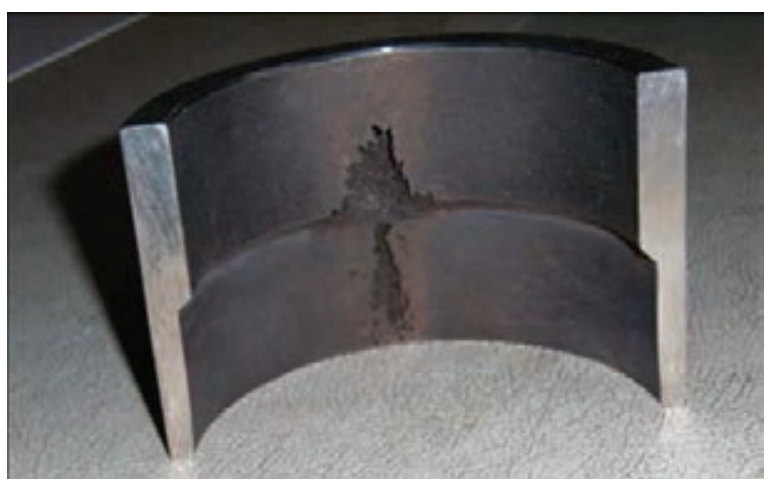

Puc. 3. Фрагмент трубопровода с кавитационной каверной (дефектом)
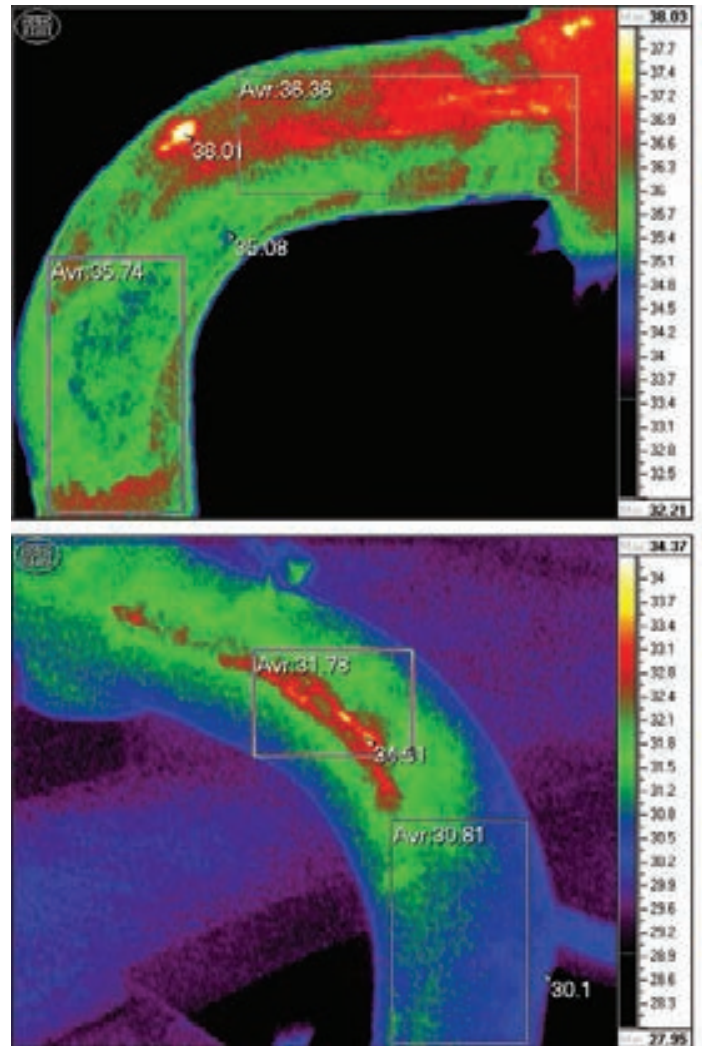

Puc. 4. Зоны кавитационной эрозии, выявленные при смене ракурсов на двух участках трубопровода
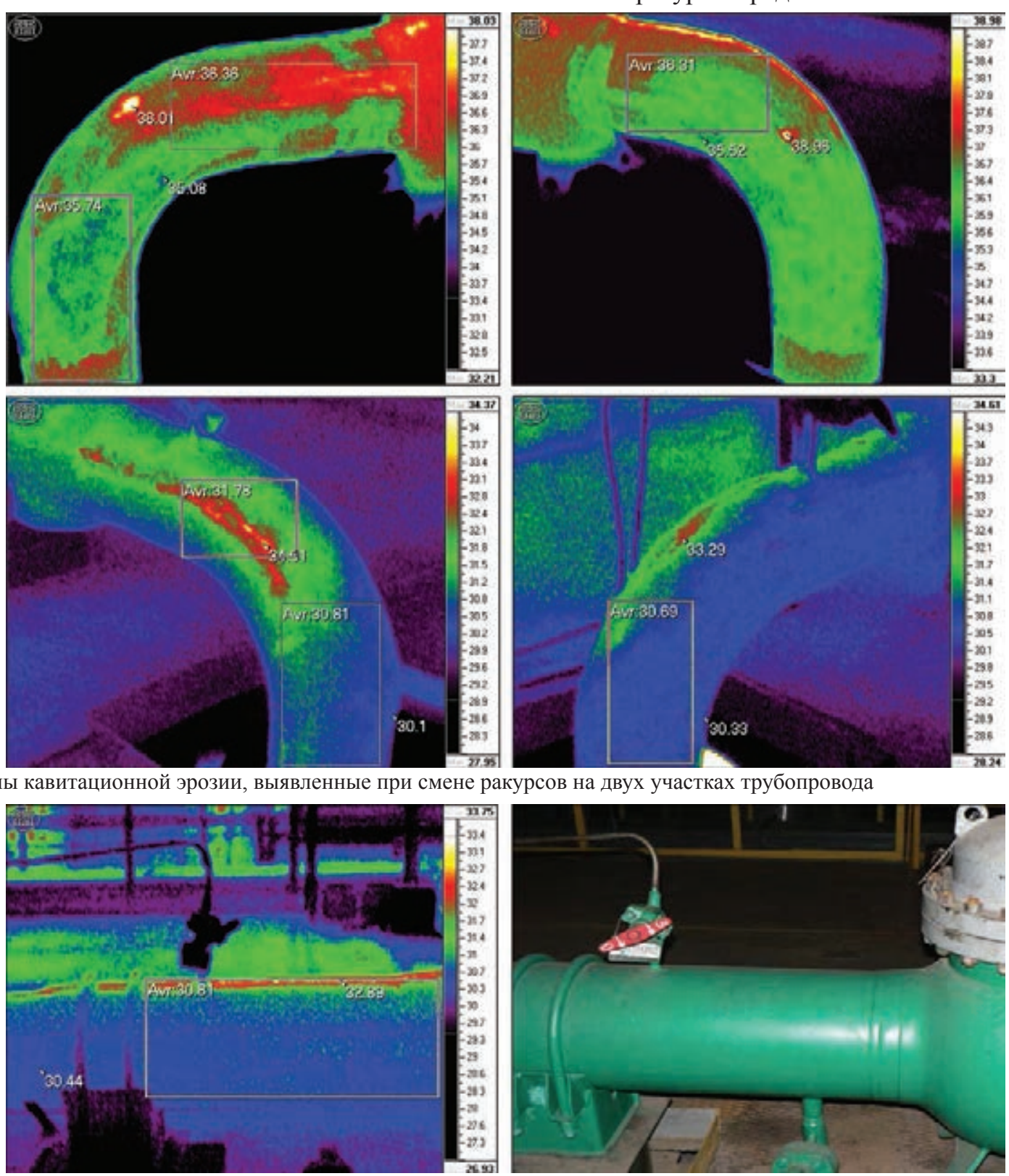

Puc. 5. Температурная аномалия, выявленная на участке трубопровода с запорным устройством 
витационными дефектами. В подтверждение этого факта свидетельствует то, что обнаруженные места находятся на повороте трубопровода (где происходит резкое торможение потока конденсата); при смене ракурса тепловизионной съемки обнаруженные зоны не изменили своего положения.

Схожие результаты были получены при термографировании нескольких участков трубопроводов с аналогичной формой.

Согласно теории кавитационные области образуются в местах повышения давления в потоке жидкости при дросселировании (уменьшении сечения трубопровода), местах стыков и на участках с запорно-регулирующей аппаратурой. Кавитация вызывает разъедание элементов проточной части запорных органов. Было исследовано несколько таких объектов.

Полученные результаты подтвердили критичность указанных мест к возникновению дефектов. На рис. 5 показана одна из выявленных температурных аномалий.

Средняя температура трубы составляет $T_{\text {тр }}=30,81^{\circ} \mathrm{C}$. Уровень засветки от посторонних источников колеблется в пределах $\Delta T_{\text {зас }}=1,5^{\circ} \mathrm{C}$. В месте предполагаемого дефекта температура составляла $T_{\text {деф }}=33,89^{\circ} \mathrm{C}$.

На рис. 5 обнаруженные температурные аномалии отличаются от зарегистрированных ранее (см. рис. 4) на поворотных проточных участках. Очевидно это связано с особенностями движения потоков после механизма управления потоком в запорно-регулирующей аппаратуре.

Результаты, полученные при термографировании, совпали с результатами проведенной УЗ-дефектоскопии.

\section{Выводы}

Проведенные исследования дали положительный результат и показали перспективность применения термографии для определения состояния металлов в трубопроводах.

Для прогнозирования сроков эксплуатации трубопроводов необходимы точные значения уменьшения толщины труб, которые можно получить с помощью контактного УЗ-метода. Термография дает возможность быстрого получения информации о наличии несоответствий состояния металла в период эксплуатации и в период планово-предупредительных ремонтов.
Термографию можно определить как экспресс-контроль, позволяющий быстро устанавливать по температурным аномалиям области для детального изучения другими, более точными методами. Это позволит экономить время и повысит качество и оперативность контроля. Внедрение метода тепловой термографии позволит определять участки первоочередного неразрушающего контроля с целью оптимизации объема контроля (планирование объемов и сроков ремонта оборудования и трубопроводов по их фактическому состоянию).

Закономерности кавитации и меры борьбы с ней до настоящего времени мало изучены и потому задача эффективного обнаружения кавитационных каверн в гидрооборудовании является очень важной. Использование акустического метода диагностирования кавитационных дефектов в элементах проточной части гидросистем нецелесообразно, так как требует длительного времени, во много раз большего, чем обнаружение другими методами. Поэтому обнаружение «теплового следа» при кавитации является важным результатом. После проведения дополнительных исследований тепловой метод может стать еще одним методом прогнозирования кавитационных разрушений гидравлических систем.

1. Вавилов В. П. Инфракрасная термография и тепловой контроль. - М.: Спектр, 2009. - 544 с.

2. Xavier $P . \quad V$. Maldague. Theory and Practice Infrared Technology for Nondestructive Testing. - New York, JohnWiley\&Sons INC, 2001. $-684 \mathrm{p}$.

3. Стороженко В. А., Мешков С. Н., Гаптракипов А. А. Теплофизическое моделирование процессов выявления дефекта в объектах цилиндрической формы при тепловом неразрушающем контроле // Техн. диагностика и неразруш. контроль. - 2004. - № 4. - С. 37-40.

4. Применение термографического метода контроля для определения содержания жидкой фазы в газопроводах / В.А. Стороженко, А.В. Мягкий, С.А. Сапрыкин, С.Н. Мешков // Методи та прилади контролю якості. - 2009. - № 23. - C. 12-15.

5. Мешков С. Н., Малик С. Б., Мягкий А. В. Оценка возможности применения тепловизионного метода для обнаружения дефектов в напорных трубопроводах // Сб. докл. 6-й Межд. НТК «Метрология и измерительная техника». - Харьков: ННЦ «Институт метрологии», 2008. - С. 154-157.

6. Нефедов Ю. И., Стороженко В. А., Брагин С. С. Кавитационный энергосберегающий теплогенератор-гидротаран // Энергетика. Энергосбережение. Энергоаудит. 2011. - № 5. - C. 9-14.

7. Пирсол И. Кавитация - М: Мир, 1975. - 96 с.

8. Богачев И. Н. Кавитационное разрушение и кавитационные сплавы. - М.: Металлургия, 1972. - 192 с.

The thermographic examination results of nuclear power plant high pressure pipelines and main condensate pipelines are considered. The conditions and technique of several sections thermal control are specified. Is found, that cavitation defects have a "heat trace". The use of thermography as an effective express-control method for quickly determining the temperature anomalies space for a detailed study of other methods is proposed. 
УДК 620.13 .40

\title{
ЦИКЛИЧЕСКАЯ ПРОЧНОСТЬ ПОВРЕЖДЕННОГО ТРОЙНИКОВОГО СОЕДИНЕНИЯ
}

\author{
П. С. ЮХИМЕЦ ${ }^{1}$, С. В. КОБЕЛЬСКИЙ', В. В. ФИЛИПЕНКОВ ${ }^{3}$ \\ ${ }^{1}$ ИЭС им. Е.О. Патона НАНУ. 03680, г. Киев-150, ул. Боженко,11. E-mail: office@paton.kiev.ua \\ ${ }^{2}$ ИПП им. Г.С. Писаренко НАНУ. 01014, Киев-014, ул. Тимирязевская, 2. E-mail: ips@ipp.kiev.ua \\ ${ }^{3}$ Рижский техн. ун-т. LV-1048, г. Рига, ул. Азенес, 12/14. E-mail: info@rtu.ev
}

\begin{abstract}
Рассмотрено влияние объемного поверхностного дефекта на напряженно-деформированное состояние тройникового соединения и его прочность при циклическом изменении внутреннего давления при расположении дефекта на поверхности трубы, противолежащей ответвлению. Результаты расчетов показывают, что для оценки остаточного ресурса Т-соединения в этом случае может быть использована в качестве консервативной оценки предложенная раннее инженерная методика оценки циклической прочности прямолинейного трубопровода. Этот вывод был сделан на основе серии расчетов МКЭ. Достоверность полученных результатов проверена в ходе циклических испытаний полноразмерного тройника. Библиогр. 7, табл. 6, рис. 6.
\end{abstract}

Ключевы е слова: тройниковое соединение, прочность, остаточный ресурс, коррозионный дефект, эрозионно-коррозионный износ

Основное внимание при выполнении этой работы направлено на исследование влияния объемного поверхностного дефекта (ОПД)) на прочность тройникового соединения при циклическом внутреннем давлении. Согласно данным работы [1] имеются две основные зоны поражения Т-соединения эрозионно-коррозионным износом: внутренняя поверхность основной трубы, противолежащая ответвлению (рис. 1 , зона $I$ ) и внутренняя поверхность ответвления в области его сопряжения с основной трубой в направлении продольной оси основной трубы (зона II). Очевидно, что образование коррозионных повреждений при подземной прокладке трубопровода возможно на всех участках его наружной поверхности.

При определенных условиях коэффициент концентрации напряжений (ККН) в ОПД может превысить конструктивную концентрацию напряжения в области пересечения основной трубы и ответвления. В этом случае напряжения в ОПД приобретают особое значение.

Одним из возможных вариантов поиска остаточного ресурса поврежденного тройника является непосредственное использование инженерной методики, приведенной в работе [2]. Очевидно, что такой подход может быть оправданным, если он учитывает напряженно-деформированное состояние (НДС) соединения и, по крайней мере, исключает необоснованное продление его срока эксплуатации. Основные положения методики включают:

- определение ККН на основе геометрических параметров ОПД и трубопровода;

(С П. С. Юхимец, С. В. Кобельский, В. В. Филипенков, 2015
- построение усталостной кривой с использованием характеристик прочности и пластичности материала трубы;

- определение числа циклов за время эксплуатации трубопровода;

- расчет допускаемого числа циклов и остаточного ресурса на основании указанных выше данных.

В данной работе предпринята попытка оценить остаточный ресурс тройника с ОПД, расположенного в области, противолежащей ответвлению, в случае: внутренней поверхности - в зоне I; наружной поверхности - в зоне III (см. рис. 1).

Серия расчетов НДС методом конечных элементов (МКЭ) [3] показала, что в качестве консервативной оценки остаточного ресурса Т-соединения может быть использована инженерная методика оценки циклической прочности поврежденного прямолинейного трубопровода [2]. Расчеты тройников были выполнены при воздействии внутреннего давления $P=1$ МПа. Достоверность полученных результатов была проверена в ходе циклических испытаний полноразмерного тройника.

Напряженно-деформированное состояние тройникового соединения. Бездефектные зоны I и III. При изложении были использованы следующие обозначения образующих на поверхности тройника (см. рис. 1). Индексы «р» и «b» относятся к поверхностной образующей трубы или ответвления, индексы «і» и «о» - к внутренней или наружной поверхности соответственно. Закрепление концов тройника при воздействии внутреннего давления, как это было установлено на основании расчетов МКЭ, не оказывает существенного влияния на 


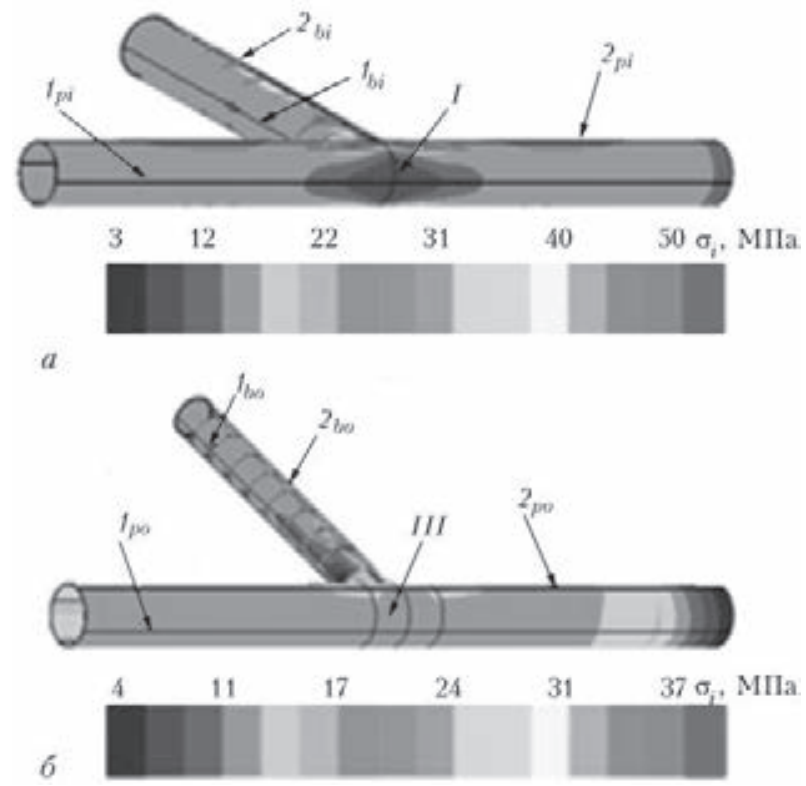

Puc. 1. Обозначение образующих и распределение напряжений на поверхности Т-соединения: $a$ - внутренняя; $\sigma$ - наружная поверхность

его НДС. Поэтому далее в тексте закрепление концов тройникового соединения, если это специально не оговаривается, соответствует условиям эксперимента: один торец трубы является фиксированным, другой ее торец и торец ответвления - свободными.

Некоторые отличительные особенности НДС в зонах I и III рассматриваются на примере:

- неравнопроходного тройника (диаметр трубы и ответвления неравны) $159 \times 4,8-108 \times 4(159 \times 4,8$ - диаметр $\times$ толщина стенки трубы, мм; 108×4 диаметр $\times$ толщина стенки ответвления, мм);

- равнопроходного тройника $159 \times 4,8-159 \times 4,8$.

В случае тройника $159 \times 4,8-108 \times 4$ неравномерность НДС в зонах I, III незначительная - повышение напряжений в зоне $I$ составляет $\approx 9 \%$, а в зоне III их понижение $\approx 6 \%$. Данная тенденция становится более выраженной по мере приближения диаметра ответвления к размеру основной трубы (рис. 2). В случае равнопроходного соединения повышение напряжений в зоне $I$ достигает $\approx 75 \%$, а понижение в зоне $I I I \approx 40 \%$.

Данные оценки влияния толщины стенки основной трубы и ответвления на НДС зоны $I$ тройникового соединения, полученные на основании расчетов МКЭ [3], представлены на рис.3. Как следует из рисунка, при увеличении толщины основной трубы в два раза (кривые 1,2$)$ ККН в зоне I возрастает от 1,09 до 1,27; при таком же увеличении толщины ответвления (кривые 2 и 3 ) концентрация снижается с 1,27 до 1,15 . В случае равнопроходного тройника при увеличении толщины в два раза значение ККН снижается на $6 . .7 \%$.

Тройник с дефектом. Зависимость напряжений в дефекте от месторасположения (внутрен-

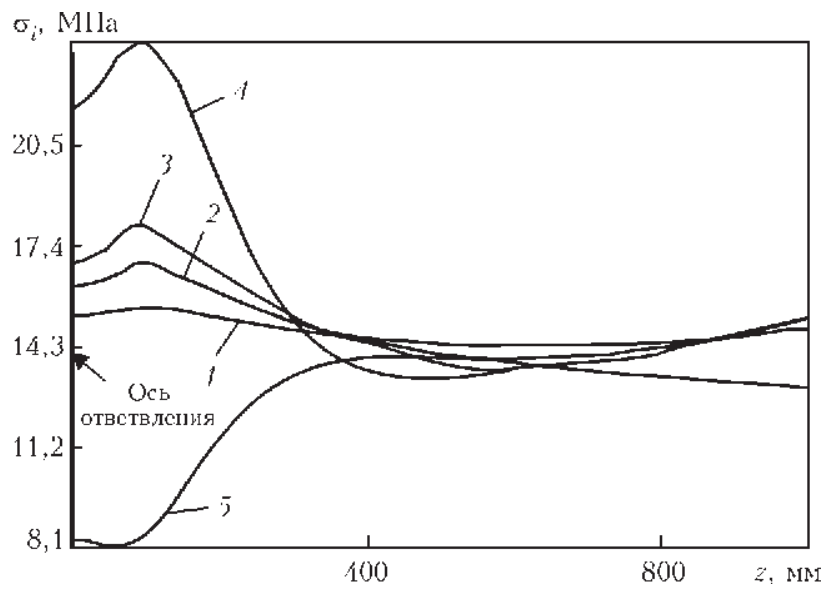

Puc. 2. Распределение интенсивности напряжений вдоль образующей 1 (см. рис. 1 ) тройника: $1-159 \times 4,8-108 \times 4 ; 2-$ $159 \times 4,8-130 \times 4 ; 3-159 \times 4,8-140 \times 4 ; 4-159 \times 4,8-159 \times 4,8$; 5 - вдоль образующей $1_{p o}$ тройника $159 \times 4,8-159 \times 4,8$

няя (зона $I$ ) или внешняя (зона $I I I)$ поверхность Т-соединения) была исследована на основе расчета МКЭ тройника $159 \times 6,2-108 \times 5,5$. Геометрические параметры соединения, в том числе размеры дефекта (глубина $b=3,8$ мм, длина $2 c=70 \mathrm{mм,}$ ширина $2 d=28$ мм) соответствовали геометрическим параметрам натурного образца.

В случае расположения повреждения на внешней поверхности трубы максимальное напряжение $\sigma_{i \max }=72,3$ МПа наблюдается в самой глубокой точке дефекта - так называемой вершине. В случае внутреннего расположения максимум $\sigma_{i \max }=60,1$ МПа сдвигается вдоль продольной оси симметрии дефекта и позиционируется на промежуточной глубине. Более высокие напряжения на поверхности наружного дефекта, а также смещение максимального напряжения из вершины дефекта в случае внутреннего расположения может, по-видимому, объясняться двумя основными причинами: дополнительным изгибом стенки трубы; неравномерностью распределения напряжений по толщине стенки.

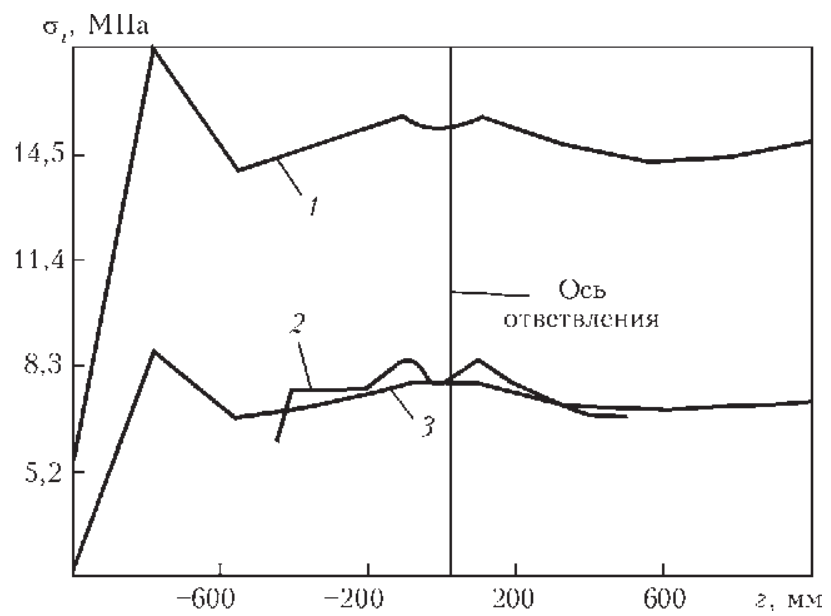

Puc. 3. Распределение интенсивности напряжений вдоль образующей $1_{p i}$ тройника: 1 - $159 \times 4,8-108 \times 4 ; 2-159 \times 10$ $108 \times 4 ; 3-159 \times 10-108 \times 8$ 
В случае расположения дефекта в зоне III его вершина - точка наибольшей концентрации напряжений - вследствие геометрической неоднородности совпадает с более напряженными по толщине стенки слоями металла. Напротив, для дефекта зоны $I$ характерно наложение вершины на менее напряженные слои. Очевидно, что максимальное напряжение представляет собой комбинацию геометрической концентрации и номинальных напряжений соответствующего слоя.

Основные закономерности влияния геометрических параметров дефекта на напряжения на его поверхности даны на примере повреждения в зоне $I$. Достаточно быстрый рост напряжений наблюдается при увеличении глубины дефекта $b$ (рис. 4). Так, в случае постоянной длины и ширины дефекта ( $2 c=60$ мм; $2 d=28$ мм) ККН для глубины $2 ; 2,5$ и 3 мм, составляет 1,$93 ; 2,45$ и 2,97 соответственно. К подобному росту напряжений приводит и увеличение длины дефекта.

На рис. 5 представлены результаты расчета прямой трубы $159 \times 4,8$ и тройников $159 \times 4,8-108 \times 4$ и $159 \times 4,8-159 \times 4,8$, имеющих дефект на внутренней поверхности одинакового размера ( $b=3 \mathrm{Mм}, 2 c=$ $=60 \mathrm{Mм}, 2 d=28 \mathrm{мм})$. Здесь для сравнения приведены напряжения в бездефектных тройниках $159 \times 4,8$ - $108 \times 4$ и $159 \times 4,8-159 \times 4,8$. Сопоставление указанных вариантов показывает, что максимальные напряжения возникают в дефекте, расположенном на внутренней поверхности прямолинейного трубопровода (кривая 1). Концентрация напряжений в этом случае в 1,5 раза выше, чем в тройнике с таким же повреждением в зоне I. Важно, что диаметр ответвления не оказывает существенного влияния на напряжения в дефекте (кривые 3,4 ). Таким образом, применение метода оценки остаточного ре-

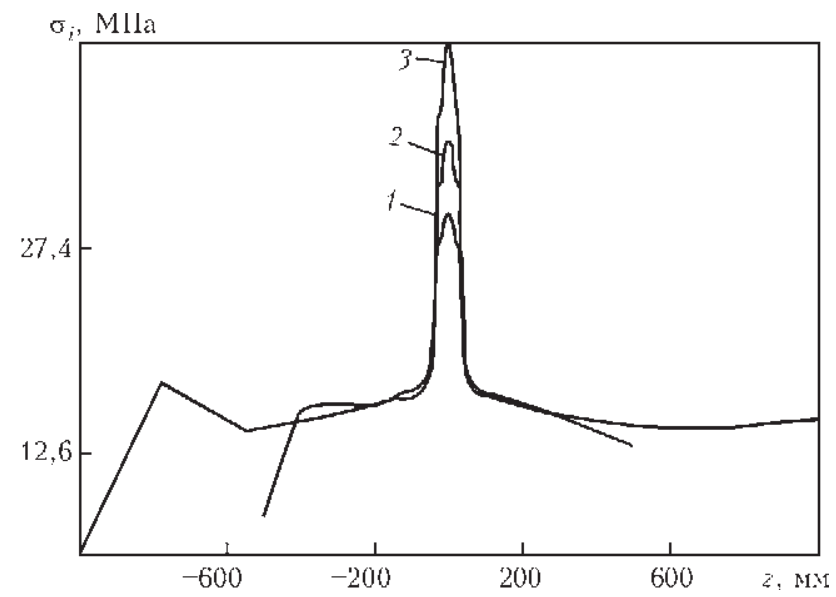

Puc. 4. Влияние глубины дефекта $b: 1-2$ мм; $2-2,5 ; 3-3$ на максимальные напряжения в зоне $I$ тройника $159 \times 4,8-108 \times 4$

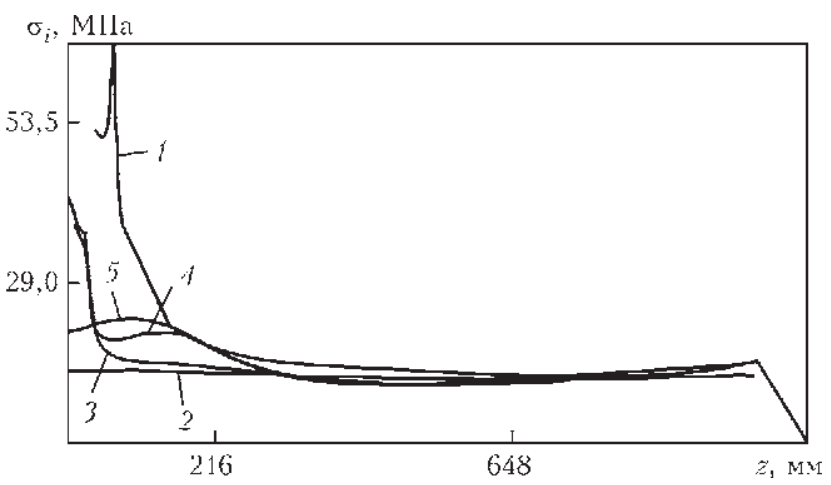

Puc. 5. Распределение интенсивности напряжений вдоль образующей $1_{p i}$ (совпадает с продольной осью симметрии): 1 прямой трубопровод $159 \times 4,8$ с ОПД; 2 - бездефектный тройник $159 \times 4,8-108 \times 4 ; 3$ - тройник $159 \times 4,8-108 \times 4$ с ОПД; 4 - тройник $159 \times 4,8-159 \times 4,8$ с ОПД; 5 - бездефектный тройник $159 \times 4,8-159 \times 4,8$ (величина ОПД: $b=3$ мм, $2 c=$ $=60 \mathrm{MM}, 2 d=28 \mathrm{MM})$

сурса прямолинейного трубопровода с ОПД [2] для расчета циклической прочности тройника с повреждением в области, противолежащей ответвлению, оправдано, поскольку с учетом изложенного выше, такой подход дает консервативный результат.

Эксперимент. Натурный образеи. Для экспериментального исследования циклической прочности использовалось бесшовное тройниковое соединение $159 \times 6,0-108 \times 5,0$ (номинальный размер), изготовленное в соответствии с ГОСТ 17376-2001 [4] из трубной заготовки по ГОСТ 8731-74 [5]. Материал тройника - сталь 20 ГОСТ 1050-88 [6]. Химический состав материала следующий, мас. \%: $0,17-0,24 \mathrm{C} ; 0,17-0,37 \mathrm{Si}$; $0,35-0,65 \mathrm{Mn} ; \leq 0,040 \mathrm{~S} ; \leq 0,035 \mathrm{P} ; \leq 0,25 \mathrm{Cr}$; $\leq 0,30 \mathrm{Ni} ; \leq 0,08 \mathrm{As} ; \leq 0,008 \mathrm{~N} ; \leq 0,30 \mathrm{Cu}$.

Механические свойства материала определяли на стандартных образцах, вырезанных из области тройника, противолежащей ответвлению в кольцевом направлении после окончания циклических испытаний. Минимальные значения результатов испытаний приведены в табл. 1.

Для изготовления испытательного образца к торцам тройника были приварены отрезки труб. Концы образца герметизированы посредством толстостенных приварных плоских днищ (рис. 6). Для подачи воды, используемой в качестве рабочей жидкости, образец снабдили нагнетательным и выпускным штуцером.

Углубление в форме части эллипсоида, имитировавшее коррозионный дефект (глубина $b=$ $=3,8$ мм; длина $2 c=70$ мм, ширина $2 d=28$ мм; ККН при упругом нагружении $\alpha_{\sigma}=6,47$ ) было механически нанесено в зоне III. Размеры де-

Т а б л и ц 1. Механические свойства материала тройника

\begin{tabular}{|c|c|c|c|c|}
\hline \hline Источник данных & Предел текучести $\sigma_{y}$ МПа & Временное сопротивление $\sigma_{t}$, МПа & Удлинение $\delta, \%$ & Сужение $\psi, \%$ \\
\hline Механические испытания & 253,1 & 428,8 & 22,7 & 50,3 \\
\hline Сертификат & 270 & 480 & 28,0 & - \\
\hline
\end{tabular}


фекта были приняты исходя из двух основных требований:

- ККН в дефекте должен превышать конструктивную концентрацию $\left(\alpha_{\sigma} \sim 3,8\right.$, МКЭ) в зоне II;

- разрушение образца при испытании, учитывая особенности испытательного оборудования, должно произойти на базе $1 . .2 \cdot 10^{4}$ циклов.

Деформации в характерных зонах тройникового соединения измерялись с помощью тензодатчиков (см. рис. 6). Для измерения деформаций на поверхности дефекта использовали датчики с базой 5 мм, в других случаях - тензодатчики с базой 10 мм.

НДС натурного образиа. Измерение деформаций проводили в первых циклах нагружения при ступенчатом подъеме давления. Экспериментальные зна-

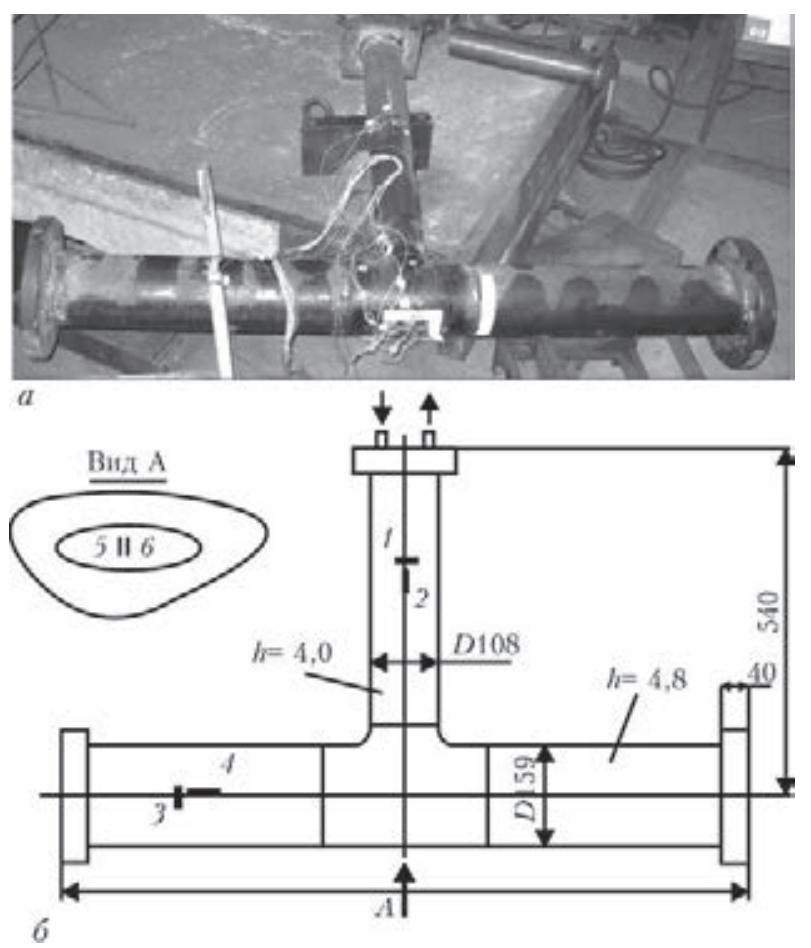

Puc. 6. Натурный образец перед испытанием ( $a$ ) и схема расположения тензодатчиков 1-6 (б) чения кольцевых $\sigma_{\varphi}$ и осевых $\sigma_{z}$ напряжений в приваренных трубных секциях представлены в табл. 2. В табл. 3 представлены результаты измерения и расчета напряжений и деформаций в модельном дефекте на поверхности тройника и прямой трубы в упругой области нагружения, а также для сопоставления расчетных значений напряжений в зоне сопряжения трубы и ответвления тройника.

Циклические гидравлические испытания. В последующем натурный образец был подвергнут циклическому гидравлическому нагружению, которое осуществлялось посредством подачи воды внутрь образца с помощью насоса через нагнетательный штуцер. Сброс давления производился через выпускной штуцер, соответственно. Нагружение выполнялось в автоматическом режиме с частотой $1,5 \ldots 2,0$ цикла в минуту.

История нагружения натурного образца приведена в табл. 4. После наработки общего числа циклов $\sum N_{i}=17550$ произошла разгерметизация образца вследствие возникновения сквозной трещины, располагавшейся в дефекте вдоль образующей $1_{\text {ро }}$.

Как следует из табл. 2, значения деформаций, измеренных в трубных секциях, превышали расчетные величины, что могло быть следствием некоторой несоосности, наблюдавшейся между осями данных элементов натурного образца и соответствующей осью тройника.

В табл. 3 представлены расчетные и экспериментальные данные о НДС наиболее нагруженных зон тройника при упругом нагружении. Видно довольно близкое соответствие между окружными напряжениями $\varepsilon_{\varphi}$, измеренными с помощью тензодатчиков на поверхности дефекта $\left(3,5 \cdot 10^{-4}\right)$, и деформациями $\varepsilon_{\varphi}$, рассчитанными МКЭ $\left(3,7 \cdot 10^{-4}\right)$ : относительная разница составляет $\Delta=5,7 \%$. Согласно результатам расчета МКЭ, максимальные окружные деформации на поверхности дефекта превышают их интенсивность в

Т а бл и ц а 2. Напряжения на наружной поверхности приварных труб (внутреннее давление 1 МПа)

\begin{tabular}{|c|c|c|c|c|c|c|}
\hline \multirow[b]{2}{*}{$D_{0}, \mathrm{мм}$} & \multicolumn{2}{|c|}{$\sigma_{\varphi,}, \mathrm{M \Pi а}$} & \multirow{2}{*}{$\begin{array}{c}\text { Величина отноше- } \\
\text { ния напряжений } \\
\text { Эксперимент/ } \\
\text { Расчет } \\
\end{array}$} & \multicolumn{2}{|c|}{$\sigma_{\mathrm{z}}, \mathrm{MПа}$} & \multirow{2}{*}{$\begin{array}{c}\text { Величина отноше- } \\
\text { ния напряжений } \\
\text { Эксперимент/ } \\
\text { Расчет } \\
\end{array}$} \\
\hline & $\begin{array}{l}\text { Эксперимент } \\
\text { (среднее) }\end{array}$ & Расчет & & $\begin{array}{l}\text { Эксперимент } \\
\text { (среднее) }\end{array}$ & Расчет & \\
\hline 159 & 19,4 & 15,1 & 1,28 & 9,8 & 7,6 & 1,29 \\
\hline 108 & 12,1 & 12,0 & $\approx 1$ & 7,1 & 6,0 & 1,18 \\
\hline
\end{tabular}

Т а бл и ц 3 . Деформации и напряжения на поверхности тройника

\begin{tabular}{|c|c|c|c|c|c|c|c|}
\hline \multicolumn{6}{|c|}{ Дефект } & \multicolumn{2}{|c|}{$\begin{array}{c}\text { Поверхность сопряжения } \\
\text { труба-ответвление }\end{array}$} \\
\hline \multicolumn{5}{|c|}{ в тройнике } & в прямой трубе & внутренняя & наружная \\
\hline \multicolumn{2}{|l|}{$\varepsilon_{\varphi} \cdot 10^{-4}$} & \multicolumn{2}{|r|}{$\varepsilon_{i} \cdot 10^{-4}$} & \multirow{2}{*}{$\frac{\sigma_{i}, \text { МПа }}{\text { МКЭ }}$} & \multirow{2}{*}{$\frac{\varepsilon_{i} \cdot 10^{-4}}{\mathrm{MKЭ}}$} & $\sigma_{i}, \mathrm{M \Pi а}$ & $\sigma_{i}, \mathrm{MПа}$ \\
\hline $\begin{array}{c}\text { Показания } \\
\text { датчиков (среднее) }\end{array}$ & МКЭ & МКЭ & Данные работы [2] & & & МКЭ & МКЭ \\
\hline 3,5 & 3,7 & 3,6 & 3,3 & 7,3 & 3,7 & 4,4 & $1,2-1,3$ \\
\hline
\end{tabular}


НАУЧНО-ТЕХНИЧЕСКИЙ РАЗДЕЛ

Т а б л и ц а 4 . История циклического нагружения

\begin{tabular}{|c|c|c|c|c|c|c|c|c|}
\hline \multirow{2}{*}{$P_{\text {min }}, \mathrm{MПа}$} & \multirow{2}{*}{$P_{\max }, \mathrm{M \Pi а}$} & \multirow{2}{*}{$N_{i}$, цикл } & \multicolumn{3}{|c|}{ Эксперимент } & \multicolumn{3}{|c|}{ Данные работы [2] } \\
\hline & & & $\varepsilon_{\mathrm{ia}} \cdot 10^{-3}$ & $N_{f}$ цикл & $d_{i}$ & $\varepsilon_{i a} \cdot 10^{-3}$ & $N_{f}$, цикл & $d_{i}$ \\
\hline 1,5 & 7,5 & 9200 & 0,88 & $1,2 \cdot 10^{6}$ & 0,01 & 1,63 & 29510 & 0,31 \\
\hline 1,5 & 9,0 & 2600 & 1,24 & 93000 & 0,03 & 2,27 & 9812 & 0,26 \\
\hline 1,5 & 10,0 & 3080 & 1,64 & 28540 & 0,11 & 2,77 & 5608 & 0,55 \\
\hline 1,5 & 11,0 & 2670 & 2,63 & 6446 & 0,41 & 3,02 & 3470 & 0,77 \\
\hline \multicolumn{5}{|c|}{ Суммарная повреждаемость } & 0,56 & & & 1,89 \\
\hline \multicolumn{9}{|c|}{$\begin{array}{l}\text { Примечания: } P_{\min }, P_{\max }-\text { минимальное, максимальное давление в цикле нагружения соответственно; } \varepsilon_{i a}-\text { амлитуда ин- } \\
\text { тенсивности деформаций; } N_{i}-\text { число циклов данного } i \text {-типа; } N_{f i}-\text { число циклов до разрушения данного } i \text {-типа; } d_{i}-\text { доля } \\
\text { повреждаемости, аккумулированная в дефекте в циклах нагружения данного } i \text {-типа }\end{array}$} \\
\hline
\end{tabular}

$\approx 1,028$ раза. Использовав данное соотношение для пересчета максимального значения интенсивности деформаций на поверхности дефекта согласно данным работы [2] в деформацию $\varepsilon_{\varphi}$, находим, что ее относительная разница по отношению к экспериментальному значению составляет $\Delta \approx-3,1 \%$. В свою очередь, расчетное (МКЭ) значение интенсивности деформации в ОПД в зоне III $\left(\varepsilon_{i}=3,6 \cdot 10^{-4}\right)$ практически достигло величины соответствующей характеристики в дефекте такого же размера, расположенном на поверхности прямой трубы $\varepsilon_{i}=3,7 \cdot 10^{-4}$.

Измерение деформаций во время первых $10 . .20$ циклов каждого заданного уровня изменения давления показали, что амплитуда циклических деформаций стабилизировалась. Величины стабилизированных значений были на $15 \ldots 20 \%$ ниже, чем деформации в «нулевом» полуцикле, вследствие чего накопленная остаточная деформация была пренебрежимо малой и могла не учитываться при оценке повреждаемости. Таким образом, деформирование в дефекте происходило в условиях жесткого нагружения.

Согласно табл. 4, усталостное повреждение, накопленное металлом в дефекте к моменту разрушения, составляло $\Sigma d_{j i}=0,56$. Следует отметить, что усталостное повреждение, накапливаемое при малоцикловом нагружении, обычно находится в диапазоне $d=0,5 \ldots 1,5$ [7].

Относительно невысокое значение накопленного повреждения может быть результатом использования при построении расчетной усталостной кривой заниженных механических свойств средних по толщине стенки слоев металла тройника. В то же время расчет остаточного ресурса согласно [2] представляется надежной консервативной оценкой, $d=1,89$. Оценку усталостного повреждения в ОПД в эксперименте осуществляли с использованием линейного правила суммирования повреждаемости:

$$
\mathrm{d}_{\mathrm{f}}=\sum \mathrm{d}_{\mathrm{fi}}=\sum \frac{\mathrm{N}_{\mathrm{i}}}{\mathrm{N}_{\mathrm{fi}}},
$$

где $N_{f i}$ - число циклов до разрушения в циклах i-го типа.

\section{Выводы}

Для оценки малоцикловой прочности бесшовного тройникового соединения с объемным поверхностным дефектом может быть использован расчет циклической прочности поврежденного прямолинейного трубопровода. Если дефект имеет одинаковые размеры и расположен в области тройника, противолежащей ответвлению, такой расчет дает надежный консервативный результат.

В случае расположения дефекта на наружной поверхности тройника в области, противолежащей ответвлению, напряжения в дефекте в зависимости от его геометрических параметров могут достигать значения напряжения в дефекте таких же размеров на поверхности прямолинейного трубопровода и превышать напряжения в области сопряжения труба-ответвление. Повреждение такого же размера на внутренней поверхности упомянутой области тройника по критериям малоцикловой прочности является менее опасным.

Работа выполнена при поддержке со стороны проекта INNOPIPES GA-2012-318874.

1. Hiromi Shiihara. Research Institute Nippon Kaiji Kyokai (ClassNK), "Current wall thinning measured on piping system of main \& aux. boiler plant in ships", ASME-PVP 2008, USA (2008).

2. Юхимеи П. С. Оценка остаточного ресурса трубопровода с коррозионным повреждением с учетом изменения параметров дефекта в процессе эксплуатации // Цільова комплексна програма НАНУ «Проблеми ресурсу і безпеки експлуатації конструкцій, споруд та машин». - Київ: IE3 ім. С.О. Патона, 2009. - С. 404411.

3. Програмне забезпечення «Тривимірне скінчено елементне моделювання теплового і теплонапруженого стану елементів машинобудівних конструкцій (SPACE)» / Система сертифікації УкрСЕПРО. - Сертифікат відповідності № UA1.017.0054634-04. - 2004.

4. ГОСТ 17376-2001. Детали трубопроводов бесшовные приварные из углеродистой и низколегированной стали. Тройники. Конструкция. - Введ. 01.11.2001.

5. ГОСТ 8731-74. Трубы стальные бесшовные горячедеформированные. Технические требования. - Введ. 01.01.1976.

6. ГОСТ 1050-88. Прокат сортовой, калиброванный, со специальной отделкой поверхности из углеродистой качественной конструкционной стали. Общие технические условия. - Введ. 01.01.1991.

7. Когаев В. П., Махутов Н. А., Гусенков А. П. Расчеты деталей машин и конструкций на прочность и долговечность. - М.: Машиностроение, 1985. - С. 224.

Поступила в редакичию 21.04.2015 


\title{
ПЕРЕВІРКА ПРАЦЕЗДАТНОСТІ ТА ЕФЕКТИВНОСТІ БАГАТОРІВНЕВОЇ СИСТЕМИ КОНТРОЛЮ ВІБРАЦІЇ АВІАЦІЙНИХ ДВИГУНІВ
}

\author{
О. М. ПАВЛОВСЬКИЙ \\ НТУУ «Київський політехнічний ін-т». 03056, м. Київ, пр-т Перемоги, 37. E-mail: a_pav@ukr.net
}

\begin{abstract}
Підтверджено працездатність та ефективність розробленої інформаційної моделі багаторівневої системи контролю вібрації авіаційних двигунів, яка має три рівні функціонування. Перший рівень забезпечує виконання контрольних функцій вібраційного стану авіаційного двигуна. Другий та третій функціональні рівні системи забезпечують виконання діагностичних функцій - виявлення дефектів лопаток турбокомпресора та тріщини валу. Підтверджена коректність реакції системи на подолання порогових значень вібрації для контрольного рівня. Визначено діагностичні ознаки для рівня діагностики пошкодження лопаток робочих коліс. Встановлено зміну значень діагностичних ознак при розвитку пошкоджень лопаток робочих коліс та тріщин ротора авіаційного двигуна. Бібліогр. 6, рис. 5.
\end{abstract}

Ключов і слова: вібрація авіаційних двигунів, багаторівнева система контролю вібрації, вейвлет-розкладання, основна роторна гармоніка, трішиноподібне пошкодження вала

Забезпечення експлуатаційної надійності авіаційних газотурбінних двигунів (ГТД) грунтується на принципі попередження несправностей, пошкоджень та відмов двигунів в експлуатації. Необхідною умовою цього є високий рівень розвитку систем діагностування, а однією з вимог, що пред’являються до засобів діагностики і контролю ГТД, є раннє виявлення пошкоджень і дефектів. Практично всі типи двигунів характеризуються сукупністю однакових найбільш небезпечних пошкоджень та несправностей роторних елементів, таких як: тріщини, забоїни та обриви лопаток компресора; забоїни та прогари лопаток турбіни; руйнування валів та заклинювання роторів. Діагностика таких пошкоджень на етапі їх початкового розвитку забезпечить попередження відмов і руйнування двигуна в польоті.

Для діагностики ГТД в експлуатації використовуються контроль наявності та концентрації металів у мастилі, контроль параметрів вібрації та шуму, аналіз параметрів робочих процесів ГТД, які реєструються в польоті. Діагностування відбувається на стаціонарних режимах експлуатаціï, а обмеження маси бортового обладнання зумовлює використання тільки простих алгоритмів діагностування. Система контролю вібрації двигуна (СКВД) входить до складу бортової системи керування та контролю ГТД. Головним завданням бортової СКВД є попередження передаварійних станів двигуна у разі перевищення вібрацією встановлених значень. Функціональні можливості бортових СКВД обмежуються лише контролем рівнів вібрації на основних роторних гармоніках та порівнянням їх значень зі встановленими

(C) О. М. Павловський, 2015 нормами на стаціонарному режимі. Такі системи зараз непридатні для контролю вібрації на нестаціонарних режимах, вони не забезпечують оперативного виявлення найбільш небезпечних початкових пошкоджень роторних елементів, які під час експлуатації ГТД можуть призвести до руйнування двигуна.

Введення в експлуатацію нових ГТД підвищеної контрольної придатності, модернізація елементної бази бортових СКВД дає можливість застосування сучасних методів цифрової обробки вібраційних сигналів на стаціонарних та нестаціонарних режимах експлуатації ГТД. Це дозволяє реалізувати в бортових СКВД не тільки наявну зараз контрольну функцію, а й діагностичні функції для раннього виявлення найнебезпечніших пошкоджень роторних елементів.

В роботі [1] запропоновано структуру такої багаторівневої системи контролю вібрації (БСКВ) на основі об“єднання модернізованої підсистеми контролю вібрації на основних роторних гармоніках для стаціонарного режиму та двох нових підсистем для діагностики пошкоджень роторних елементів на стаціонарних і нестаціонарних режимах. Це дозволить розширити функціональні можливості існуючих бортових систем контролю вібрації і забезпечить виявлення найбільш небезпечних пошкоджень роторних елементів та попередження передаварійних станів ГТД в експлуатації. Спрощену схему БСКВ наведено на рис. 1. Перший рівень функціонування є основним для забезпечення попередження передаварійних станів і на ньому відбувається безпосередній контроль рівня вібрації на основних роторних гармоніках на стаціонарному режимі роботи. Рівень був модернізований шляхом використання сучасної 


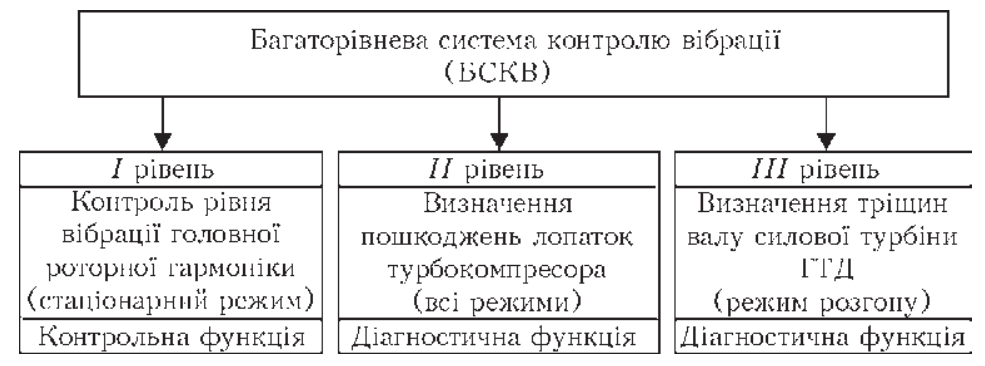

Рuc. 1. Спрощена схема багаторівневої системи контролю вібрації

цифрової елементної бази та цифрової вузькосмугової фільтрації [2]. Другий рівень призначений для діагностування початкових тріщин лопаток турбокомпресора, функціонування діагностичного апарату цього рівня відбувається на стаціонарному та нестаціонарних режимах експлуатації двигуна [3]. Третій рівень призначений для виявлення тріщиноподібного пошкодження валу силової турбіни при розгоні ротора ГТД [4].

Для оцінки працездатності та ефективності системи було створено ï̈ інформаційну модель. Структурну схему інформаційної моделі БСКВ наведено на рис. 2, у відповідності до якої інформаційна модель, як і запропонована система, виконує перераховані нижче контрольні та діагностичні функції.

Перший рівень функиіюнування (контроль вібрачії на основних роторних гармоніках на стаціонарному режимі роботи двигуна) призначений для:
- формування вібраційних сигналів;

- виділення основної роторної гармоніки шляхом цифрової вузькосмугової фільтрації на стаціонарних режимах роботи двигуна;

- порівняння амплітуди усередненого значення роторної гармоніки з пороговими значеннями, які відповідають рівням «Підвищена вібрація» та «Небезпечна вібрація»;

- інформування користувача шляхом світлової індикації у разі перевищення порогових значень;

- запис даних у файл.

Другий рівень (діагностування пошкодження лопаток робочих коліс) призначений для:

- формування широкосмугових вібраційних сигналів, що випромінюються робочими колесами без пошкодження та 3 пошкодженням однієї чи декількох лопаток на стаціонарному та нестаціонарних режимах експлуатації ГДТ;

- вейвлет-розкладання на п'ять рівнів сформованої широкосмугової вібрації;

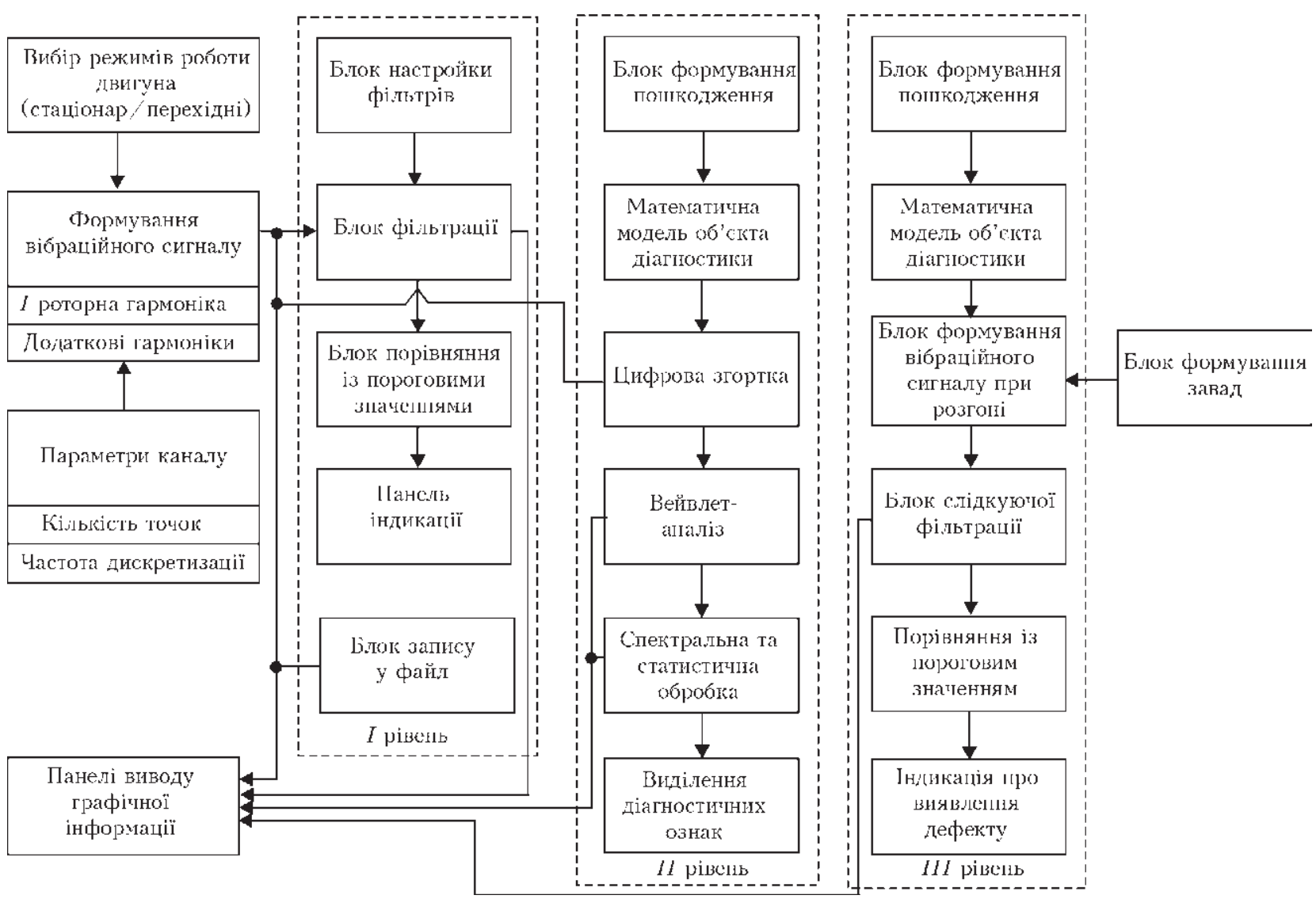

Рuc. 2. Структурна схема інформаційної моделі БСКВ 
- графічного представлення елементів вейвлет-розкладання;

- відображення спектрів елементів вейвлет-розкладання;

- визначення та відображення статистичних характеристик елементів вейвлет-розкладання;

- формування діагностичних ознак пошкодження;

- прийняття рішення про поточний функціональний стан лопаток робочого колеса.

Третій рівень (діагностування дефектів типу тріщини валу) призначений для:

- формування вібраційних сигналів, що супроводжують прискорене (при розгоні ротора ГТД) обертання валу без пошкодження та з тріщиноподібним пошкодженням;

- виділення основної роторної гармоніки на режимі розгону двигуна шляхом використання розробленого слідкуючого вузькосмугового фільтра;

- аналіза пікових значень вібрації в області субгармонічних резонансів;

- формування діагностичних ознак пошкодження;

- прийняття рішення про поточний функціональний стан валу ротора.

Для моделювання повного циклу процесу контролю та діагностики розроблена інформаційна модель має додаткові блоки генерації вібраційних сигналів, блоки формування моделей об'єктів діагностики для другого та третього рівнів та блоки формування дефектів початкових пошкоджень тріщин лопаток робочих коліс та дефектів обертових валів ротора. Для прикладу модель реалізована лише для одного вимірювального каналу вібрації ГТД, оскільки для інших каналів принцип функціонування БСКВ залишається незмінний, а кількість каналів, в залежності від обраного двигуна, буде різною.

Особливості реалізації інформаційної моделі БСКВ у вигляді віртуального приладу середовища графічного програмування NI LabVIEW наведено в роботі [5].

Перевірка функціонування першого рівня інформаційної моделі БСКВ. У відповідності до виконуваних БСКВ функцій, перший рівень системи призначений для виділення 3 широкосмугового вимірюваного сигналу вузькосмугових складових на стаціонарному режимі роботи, що відповідають основним роторним гармонікам контрольованих ступенів двигуна, визначення усередненого значення амплітуди вібрації на цих гармоніках та порівняння його з установленими пороговими значеннями (нормами). Для виділення інформативної (роторної) складової вібрації використовується цифровий вузькосмуговий фільтр Батерворта 10-го порядку, центральна частота смуги пропускання якого відповідає основній частоті обертання контрольованого ступеня ротоpa [2]. Після виділення із сигналу інформативних складових проводиться усереднення за виразом:

$$
A_{1}^{\prime}=\sqrt{\frac{1}{n} \sum_{i=1}^{n}\left(A_{i}-A_{\text {серед }}\right)^{2}},
$$

де $n$ - кількість значень; $A_{i}$ - виміряні значення амплітуди головної роторної гармоніки після фільтрації; $A_{\text {серед }}-$ середнє значення.

Для визначення поточного вібраційного стану ГТД та попередження передаварійних станів відбувається порівняння отриманого значення вібрації з установленими пороговими значеннями, що відповідають рівням «Підвищена вібрація» або «Небезпечна вібрація». При перевищенні порогових значень система сповіщає про це користувача відповідною індикацією.

Математичною умовою для прийняття рішення про поточний рівень вібрації є:

$$
\left\{\begin{array}{c}
x_{\text {скв }} \geq x_{\text {підв, }} \text {,О } s=s_{\text {підв }}, \\
x_{\text {скв }} \geq x_{\text {неб, }} \text { ТО } s=s_{\text {неб }}, \\
x_{\text {скв }}<x_{\text {підв, }} \text { ТО } s=s_{\text {норм }},
\end{array}\right.
$$

де $x_{\text {скв }}=A_{1}^{\prime}$ - середньоквадратичне значення амплітуди вібрації після фільтрації; $x_{\text {підв }}$ - порогове значення підвищеної вібрації; $x_{\text {неб }}$ - порогове значення небезпечної вібрації; $s$ - показник стану системи; $s_{\text {підв }}-$ виявлено підвищену вібрацію; $s_{\text {неб }}-$ виявлено небезпечну вібрацію; $s_{\text {нор }}-$ нормальний рівень вібрації.

Для підтвердження ефективного функціонування першого рівня БСКВ у якості порогових значень «Підвищена вібрація» або «Небезпечна вібрація» були обрані значення $-A_{\text {п }}=40 \mathrm{~mm} / \mathrm{c}$ i $A_{\mathrm{H}}=50 \mathrm{mм} / \mathrm{c}$ для двигуна МС-500 [3]. У якості тестового сигналу із вібродатчика було сформовано сигнал виду:

$$
y(t)=\sum_{i=1}^{4} A_{i} \sin \left(2 \pi f_{i} t\right)+n(t),
$$

де $A_{1}=30 \mathrm{~mm} / \mathrm{c} ; A_{2}=A_{3}=A_{4}=0,5 A_{1} ; f_{1}-100 ; f_{2}-$ $300 ; f_{3}-103 ; f_{4}-50$ Гц.

Змінюючи амплітуду головної роторної гармоніки $A_{1}$ та побічних гармонік $A_{i}$, було встановлено відповідну однозначність реакції системи на подолання порогових значень, що, у свою чергу, підтвердило працездатність першого рівня БСКВ.

Перевірка функціонування другого рівня інформаційної моделі БСКВ. Другий рівень функціонування БСКВ призначений для виконання діагностичної функції виявлення початкових пошкоджень (тріщин) лопаток робочих коліс турбокомпресора. Для виявлення складових вібраційного сигналу, що обумовлені наявністю тріщини 
лопаток робочих коліс турбокомпресора, в роботі [3] запропоновано та обгрунтовано використання вейвлет-розкладання із використанням вейвлетів сімейства Добеші 10-го порядку (db10) 3 подальшим використанням отриманого набору елементів розкладання (як окремих вибірок вібраційного сигналу) для визначення безрозмірних амплітудних характеристик: коефіцієнтів форми, фону, імпульсності та пік-фактору.

Перевірку працездатності розробленої моделі другого рівня функціонування БСКВ проведено у два етапи. На першому були виділені діагностичні ознаки, що свідчать про наявність пошкодження лопатки, а на другому встановлено функціональні залежності діагностичних ознак від параметру пошкодження та кількості пошкоджених лопаток. Для виділення діагностичних ознак було порівняно параметри апроксимацій та деталей вейвлет-розкладання для бездефектного стану робочого колеса та за наявності тріщини однієї чи декількох лопаток. Можливими чутливими параметрами у відповідності до роботи [3] було обрано максимальні і мінімальні значення, СКЗ, коефіцієнти форми та фону, пік-фактор елементів вейвлет-розкладання.

У якості сигналу стаціонарного вхідного збурення використано:

$$
y(t)=\sum_{i=1}^{5} A_{i} \sin \left(2 \pi f_{i} t\right),
$$

де $A_{1}=30 \mathrm{Mm} / \mathrm{c}, A_{2}=A_{3}=A_{4}=0,5 A_{1}, A_{5}=0,1 \mathrm{~mm} / \mathrm{c}, f_{1}=$ $=300, f_{2}=100, f_{3}=103, f_{4}=50, f_{5}=600$ Гц.

Частота п'ятої складової обрана із урахування того, що для використаного значення власної частоти лопаток робочого колеса 600 Гц забезпечується збурення резонансних коливань, що підвищує ефективність виявлення дефекту [3].

В результаті проведених модельних експериментів, обробки та аналізу вібраційних сигналів для робочого колеса з бездефектними лопатка- ми та робочого колеса при пошкодженні однієї чи декількох лопаток було встановлено, що поява та розвиток пошкодження призводить до появи постійної складової апроксимації - самого низькочастотного елементу вейвлет-розкладання. Тому у якості діагностичної ознаки доцільно прийняти значення постійної складової апроксимацій.

Для виявлення кількісної діагностичної ознаки змінювали параметр пошкодження (відносне змінювання жорсткості лопатки робочого колеса) у межах від 0,01 до 0,1 [2]. При прёдослідження було виявлено декілька параметрів, які чутливі до зміни параметру пошкодження та змінюються однозначно. Такими параметрами елементів вейвлет-розкладу є коефіцієнт форми та коефіцієнт фону [3]. Найбільша чутливість цих безрозмірних коефіцієнтів до зміни параметру пошкодження була виявлена для деталі другого рівня розкладу. Узагальнені результати дослідження наведено на рис. 3 для різних значень параметра пошкодження і різної кількості пошкоджених лопаток.

Як видно з рис. 3, $a$, при збільшенні параметра пошкодження в зазначених вище межах значення коефіцієнта форми зменшуються приблизно на $12 \%$ у порівнянні із бездефектним станом для однієї лопатки $з$ пошкодженням, а при збільшенні кількості лопаток з пошкодженням до п'яти зменшення коефіцієнта форми досягає приблизно $24 \%$.

Аналіз результатів, наведених на рис. 3,6 , показав, що при збільшенні параметра пошкодження значення коефіцієнта фону однозначно зростає: приблизно у три рази у порівнянні із бездефектним станом для однієї пошкодженої лопатки та більше ніж у п'ять разів для п’яти пошкоджених лопаток. Збільшення ознаки відбувається і при збільшенні кількості пошкоджених лопаток.

Все це дозволило сформулювати правило для прийняття рішення про функціональний стан об'єкта діагностики:

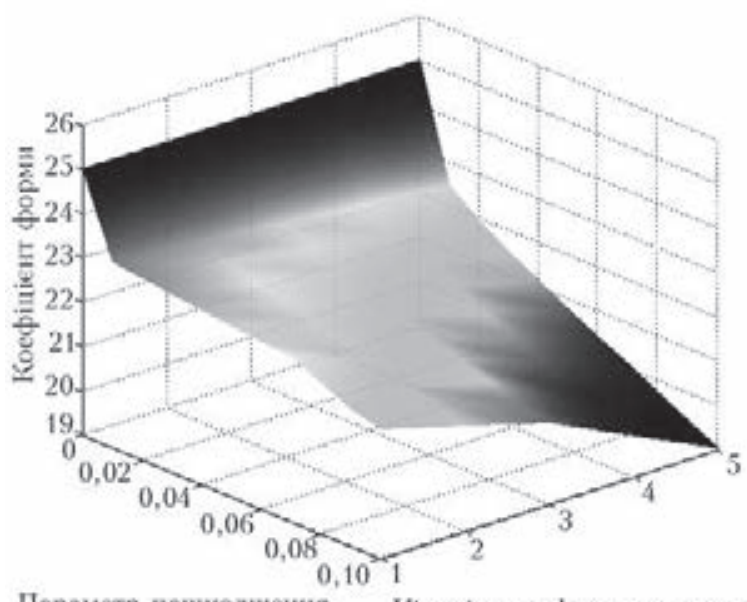

Параметр пошкодження $a$

$$
\text { c }
$$

Кількість дефектиих лопаток

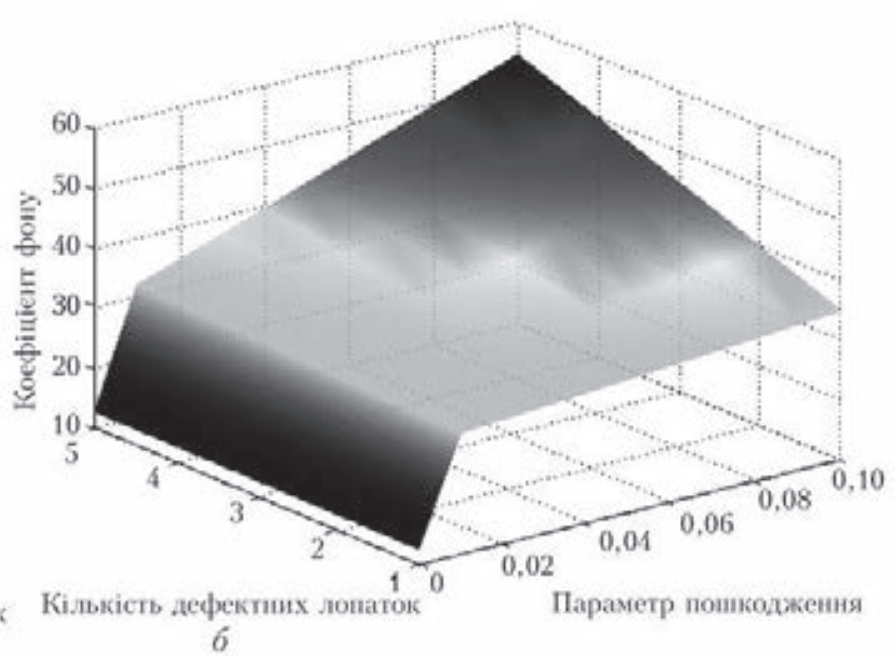

6

Puc. 3. Залежності коефіцієнтів форми (a) та фону (б) від параметра пошкодження та кількості пошкоджених лопаток 


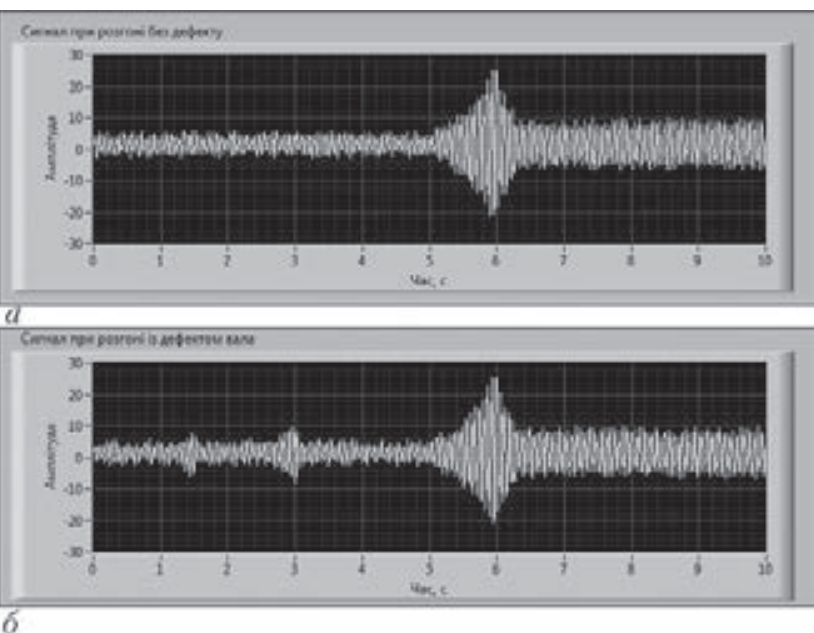

Puc. 4. Вібраційні сигнали, що аналізуються на третьому рівні БСКВ при розгоні ротора: $a$ - вал без пошкодження; $\sigma-$ вал $з$ пошкодженням

$$
\left\{\begin{array}{l}
x_{\text {пост }}>0, \text { то } s_{1}=s_{\text {деф }}, \\
k_{\text {фор }} \geq k_{\text {пор1 }}, \text { то } s_{2}=s_{\text {деф }}, \\
k_{\text {фону }}<k_{\text {пор } 2}, \text { То } s_{3}=s_{\text {деф }}, \\
s_{\Sigma} \in s_{1} \cup S_{2} \cup s_{3}, \text { то } s_{\Sigma}=s_{\Sigma \text { деф }},
\end{array}\right.
$$

де $x_{\text {пост }}-$ постійна складова апроксимацій вейвлет-розкладу; $k_{\text {фор }}-$ коефіцієнт форми; $k_{\text {фону }}-$ коефіцієнт фону; $k_{\text {пор1 }}, k_{\text {пор2 }}-$ порогові значення; $s-$ показник стану системи; $s_{1}-S_{3}-$ показники стану діагностичних ознак; $s_{\Sigma}-$ показник стану системи по трьом діагностичним ознакам; $s_{\Sigma \text { деф }}-$ показник виявлення дефекту.

Показник стану системи $s_{\Sigma}$ представляє собою кон'юнкційний показник із трьох діагностичних о3нак - постійної складової апроксимацій вейвлет-розкладання, значень коефіцієнтів форми та фону деталі другого рівня вейвлет-розкладання. Таким чином, пошкодження лопатки буде виявлено тільки за умови виконання всіх трьох нерівностей в системі (1). Такий підхід забезпечить необхідну вірогідність визначення дефекту та знизить ймовірність випадкового спрацювання системи (хибної тривоги). Результати моделювання підтвердили працездатність та ефективність інформаційної моделі другого рівня БСКВ.

Перевірка функціонування третього рівня інформаційної моделі БСКВ. Третій рівень призначений для виявлення початкових поперечних тріщин валу ротора. Діагностування відповідно до результатів роботи [4] доцільно проводити на нестаціонарному режимі експлуатації ГТД, наприклад, при розгоні двигуна. Для коректної роботи даного рівня системи необхідно виділяти лише головну роторну складову при умовах змінної (зростаючої) частоти. Для цього використовується вузькосмуговий слідкуючий цифровий фільтр Батерворта 10-го порядку [6].

Діагностичною ознакою наявності тріщини валу $\epsilon$ поява та зростання субрезонансних піків перехо-

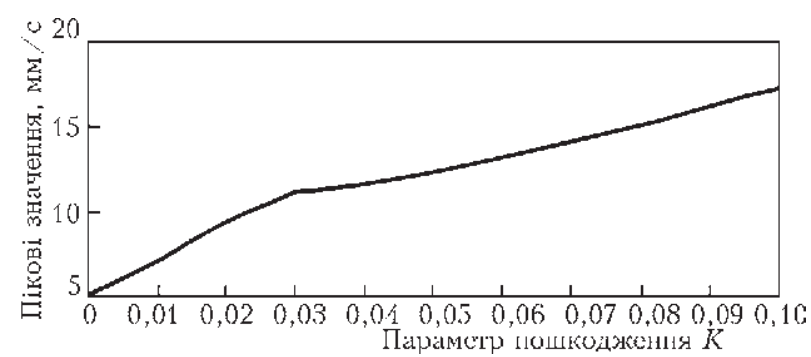

Рис. 5. Залежність пікових значень вібрації в області субгармонічних резонансів від параметра пошкодження валу ротора

ду частоти через критичне значення (до головного резонансу). Це явно спостерігається при порівнянні двох сигналів вібрації при розгоні ротора (рис. 4).

За результатами модельних експериментів було встановлено, що збільшення значення параметра пошкодження валу призводить до збільшення пікових значень вібрації в області субгармонічних резонансів (рис. 5). Таким чином, за зазначеними піковими значеннями можна приблизно оцінити наявність та ступінь пошкодження валу і прийняти рішення про захист двигуна від руйнування. Правило для прийняття рішення про функціональний стан валу ротора має вигляд:

$$
\left\{\begin{array}{c}
x_{\text {пік }} \geq x_{\text {пор }}, \text { то } s=s_{\text {деф }}, \\
x_{\text {пік }}<x_{\text {пор }}, \text { то } s=s_{\text {норм }},
\end{array}\right.
$$

де $x_{\text {пік }}$ - пікове значення амплітуди вібрації до головного резонансу; $x_{\text {пор }}$ - порогове значення амплітуди вібрації; $s$ - показник стану системи; $s_{\text {деф }}$ дефектний стан; $s_{\text {нор }}-$ бездефектний стан.

Таким чином, проведені комп'ютерні експерименти показали працездатність третього рівня інформаційної моделі БСКВ та ефективність визначення початкових пошкоджень валу ротора ГТД на нестаціонарному режимі експлуатації. Результати перевірки працездатності кожного із трьох рівнів багаторівневої системи контролю вібрації підтвердили ефективність використання БСКВ для виявлення найбільш небезпечних пошкоджень роторних елементів та попередження передаварійних станів ГТД в експлуатації.

\section{Висновки}

Розроблено інформаційну модель для дослідження працездатності та ефективності багаторівневої системи контролю вібрації авіаційних двигунів. В результаті проведених модельних експериментів для кожного з трьох рівнів системи підтверджено відповідність розробленому принципу функціонування, коректність реакції системи на перевищення порогових значень вібрації (для контрольного рівня), однозначність змінювання діагностичних ознак в залежності від параметра пошкодження роторного елемента (для діагностичних рівнів). 
Отримані результати підтверджують працездатність та ефективність розробленої моделі, а також доцільність використання розробленої багаторівневої системи контролю вібрації в сучасних системах керування та діагностики ГТД.

1. Pavlovskyi O., Bouraou N., Yatsko L. Multilevel vibration control system of aviation gas-turbine engines // Vibrations in Physical systems. - 2012. - 25. - P. 323-328.

2. Бурау Н. И., Павловский А. М. Цифровая фильтрация в системе контроля вибрации авиационных двигателей // Вісник інженерної академії України. - 2012. - № 34. C. $18-23$.

3. Методи цифрової обробки сигналів для вібраційної діагностики авіаційних двигунів / Н.І. Бурау, Л.Л. Яцко,
О.М. Павловський, Ю.В. Сопілка. - Київ: НАУ, 2012. $152 \mathrm{c}$.

4. Яико Л. Л. Комплексна діагностика технічного стану роторів авіаційних двигунів на стаціонарних та нестаціонарних режимах: дис ... канд. техн. наук. - Київ: НТУУ «КПІ», 2008. - 169 c.

5. Павловський О. М. Використання пакету LABVIEW для моделювання та аналізу ефективності системи обробки вібраційних сигналів авіаційного двигуна // Вісник НТУУ «КПІ». Сер. Приладобудування . - 2013. - № 45. - C. 148-157.

6. Разработка и исследование цифровых следящих фильтров для системы контроля вибрации авиационного двигателя на нестационарных режимах / Н.И. Бурау, А.М. Павловский, Л.Л. Яцко, А.В. Иванченко// Авиационно-космическая техника и технология. - 2013.№. 10(107). - C. 171-176.

Operability and effectiveness of the developed informational model of multi-level system for monitoring aircraft engine vibrations, having three levels of functioning, was confirmed. The first level provides fulfillment of control functions of aircraft engine vibrational state. The second and third functional levels of the system ensure fulfillment of diagnostic functions detection of turbocompressor blade defects and shaft crack. Correctness of the system reaction for overriding vibration threshold values for the control level was confirmed. Diagnostic indices for impeller blade diagnostic level were determined. Change of values of diagnostic indices at development of impeller blade damage and rotor cracks in aircraft engine was determined. 6 References, 5 Figures.

Keywords : aircraft engine vibration, multi-level system of vibration control, wavelet decomposition, main rotor harmonics, cracklike shaft damage

\section{ОПРЕДЕЛЕНИЕ ОСТАТОЧНЫХ НАПРЯЖЕНИЙ МЕТОДОМ ЭЛЕКТРОННОЙ СПЕКЛ-ИНТЕРФЕРОМЕТРИИ}

Преимущества спекл-интерферометрического метода определения остаточных напряжений

- высокая точность определения остаточных напряжений;

- бесконтактность измерений;

- оперативное определение напряжений;

- результаты определения напряжений сохраняются в виде документа;

- низкая стоимость отдельных измерений;

- возможность определения градиента напряжений в контролируемой точке.

\section{ОПЕРАТИВНИЙ КОНТРОЛЬ КАЧЕСТВА КОНСТРУКЦИЙ МЕТОДОМ ЭЛЕКТРОННОЙ ШИРОГРАФИИ}

Электронная ширография - это современный метод контроля качества конструкций, позволяющий проводить исследования в реальном масштабе времени на объектах сложной геометрической формы и произвольных размеров.

Метод эффективен для применения в промышленности в следующих направлениях:

- измерение и анализ деформаций;

- неразрушающий контроль качества конструкций, изготовленных из различных конструкционных материалов;

- оптимизация узлов и элементов конструкций в процессе их изготовления.

Основными преимуществами метода являются:

- оперативность контроля качества, бесконтактность;

- высокая чувствительность;

- возможность получения информации о деформировании поверхности контролируемого объекта;

- отсутствие требований по виброзащите и предварительной специальной подготовки исследуемой поверхности, автоматизация процесса контроля.

Мобильная ширографическая система состоит из малогабаритного ширографического интерферометра, лазера со световодом, портативного компьютера. 


\title{
ВИЗНАЧЕННЯ ТЕПЛОВІЗІЙНИМ МЕТОДОМ КОНТРОЛЮ ГЕОМЕТРИЧНИХ ПАРАМЕТРІВ ДЕФЕКТІВ ПОТЕНЦЙНО НЕБЕЗПЕЧНИХ ВАЖКОДОСТУПНИХ ОБ’ЄКТІВ
}

\author{
В. Ю. ГЛУХОВСЬКИЙ \\ IE3 ім. Є.О. Патона НАНУ. 03680, Київ-150, вул. Боженка, 11. E-mail: office@paton.kiev.ua
}

\begin{abstract}
Запропоновано новий підхід для визначення геометричних параметрів тепловізійним методом контролю потенційно небезпечних важкодоступних об'єктів. Розроблено апаратну частину, алгоритм і відповідне програмне забезпечення для розрахунку в реальному часі геометричних параметрів виявлених дефектів тепловізійним методом. Проведено ряд експериментів 3 метою визначення рівня похибки розрахунку геометричних параметрів виявлених дефектів. Бібліогр. 4 , табл. 1, рис. 8 .
\end{abstract}

Ключов і слова: неруйнівний контроль, тепловізійній метод, важкодоступні об'єкти

Одним з основних напрямків неруйнівного контролю (НК) на сьогодні є створення автоматизованих систем і комплексів, що забезпечують отримання якісно нових результатів, а саме геометричних параметрів дефектів. Це пов'язано 3 наступним визначенням фізико-механічних властивостей виробу з метою прийняття рішення про можливість їх використання за призначенням, визначення ресурсу їх функціонування. Метод теплового НК $є$ одним з найбільш продуктивних та економічних методів НК, що дозволяють визначати геометричні параметри дефектів на основі інформації про значення поверхневої температури в різні моменти часу [1].

В основі відомих методів НК теплофізичних характеристик матеріалів лежить активний тепловізйний метод НК, пов'язаний з попереднім тепловим впливом на поверхню об'єкта контролю (OK) з наступним аналізом та візуалізацією температурного поля [2].

На сьогодні більшість науковців, що працюють в області неруйнівних методів контролю, в тому числі й теплових, використовують складний математичний апарат для визначення геометричних параметрів дефектів [1-4]. Проте недоліком математичних методів $є$ трудоємність і неможливість використання в системах тепловізійного контролю, що працюють в режимі реального часу. Тому розробка нових, більш ефективних методів визначення геометричних параметрів дефектів $є$ актуальною.

3 метою визначення в реальному часі геометричних параметрів дефектів було створено програмне забезпечення для розрахунку площі дефектів на базі приладу для тепловізійної дефектометрії, схема застосування якого представлена на рис. 1. Дані дефекти виявляються при теплові-

(C) В. Ю. Глуховський, 2015 зійному контролі потенційно небезпечних і важкодоступних об'єктів. Даний програмний продукт разом з розрахунком площі дефектних ділянок контрольованої поверхні дозволяє будувати 2D або 3D сітки розрахованих дефектів. Структурна схема програмного забезпечення наведена на рис. 2.

Під час візуалізації температурного поля ОК використовується радіометрична сітка, яка виступає основним носієм інформації про температурне поле поверхні і визначає температуру в кожній його точці. Побудова термографічного зображення будується наступним чином: після опромінення тепловими фотонами болометричної матриці, внаслідок фотоефекту виникають електричні сигнали що поступають до блока обробки. Таким чином, з кожної комірки болометричної матриці виходить окремий електричний імпульс, що характеризується відповідною температурою. Блок

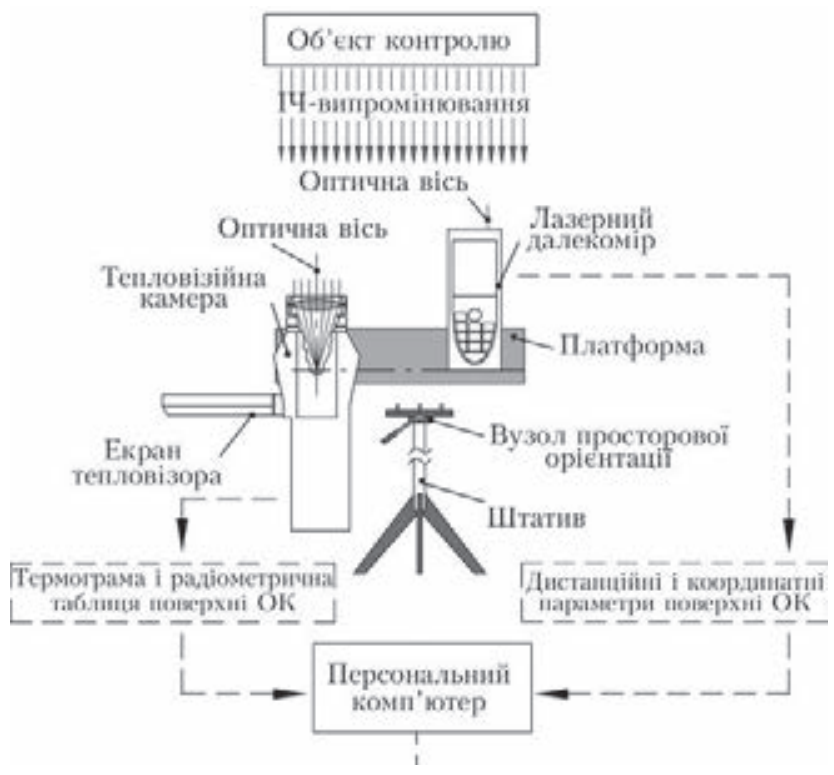

Puc. 1. Схема застосування приладу для тепловізійної дефектометрії (апаратна частина) 


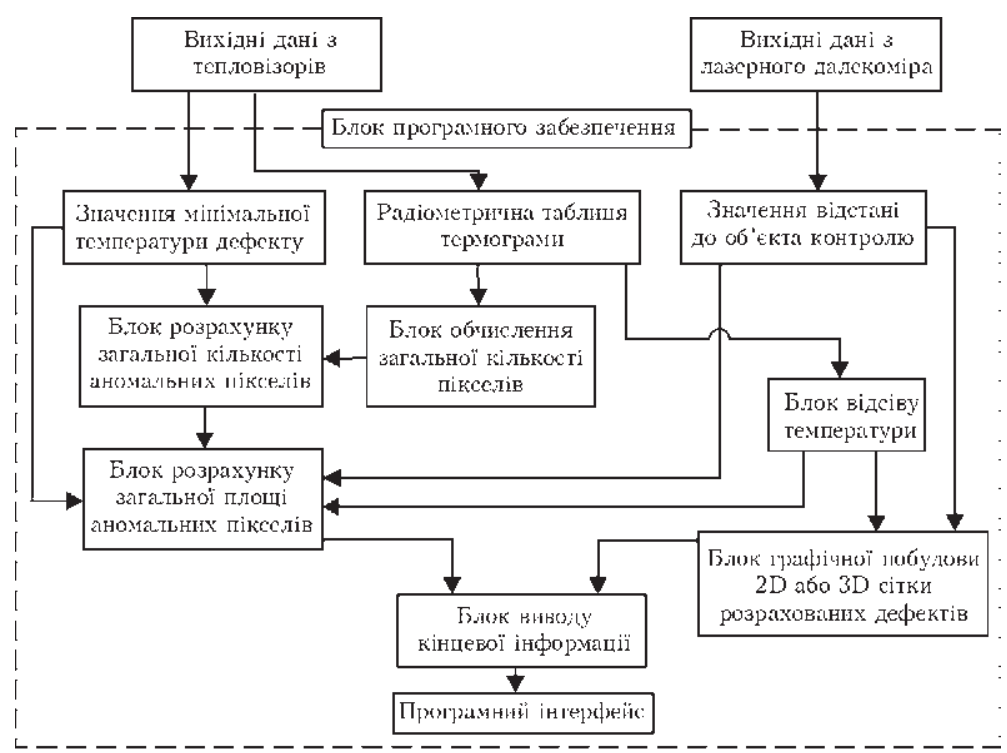

Рuc. 2. Структурна схема програмного забезпечення приладу для тепловізійної дефектометріїі

обробки електричного імпульсу будує радіометричну таблицю значень температур поверхні об’єкта контролю.

Дані з тепловізора у вигляді радіометричної таблиці з розширенням «.xls» завантажуються до програми розрахунку площі дефекта. За допомогою блока визначення мінімальної температури відбувається підрахунок мінімального значення температури, що має табличний розподіл. Дані радіометричної таблиці надходять до блока обчислення загальної кількості пікселів.

Визначення розміру пікселя, з загальної кількості яких складається термограма, є однією 3 основних задач при розрахунку загальної площі дефектних ділянок поверхні об'єкта контролю. 3 цією метою був розроблений алгоритм обчислення розміру пікселя термографічного зображення, що включений до блока обчислення загальної кількості пікселів.

Слід зазначити, що термограма є вторинним продуктом, який виникає при обробці даних, що поступають до блока обробки електричних сигналів з болометричної матриці тепловізора після iï опромінення. Основним носієм інформації про розподілення температурного поля поверхні, що контролюється, є радіометрична таблиця з масивом даних про температуру в кожній точці май-

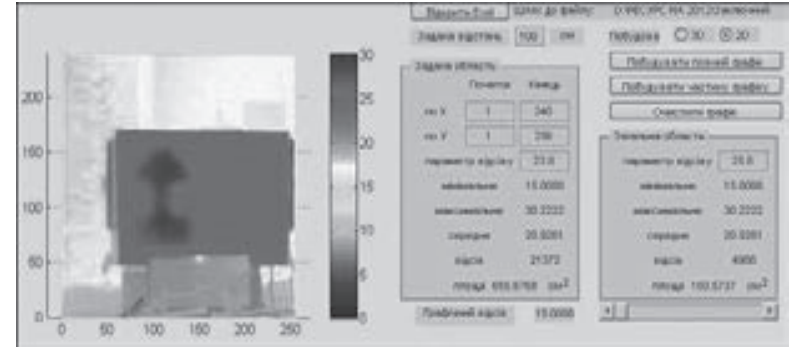

$P u c$. 3. Загальний вигляд програмного інтерфейсу з розрахованою площею дефекту і побудованою $2 \mathrm{D}$ сіткою бутньої термографічної картини. Тому для обчислення розміру окремо взятого пікселя термограми використовується радіометрична таблиця.

Основою для розрахунку зазначеної вище величини слугує алгоритм обчислення розмірності радіометричної таблиці. Знаючи загальні розміри таблиці за двома координатами і відповідно їі площу, можна розрахувати й розмірність одного пікселя. Для цього визначається загальна кількість пікселів радіометричної матриці і за допомогою операції ділення визначаються геометричні параметри пікселя.

Даний алгоритм дозволяє проводити розрахунки щодо визначення геометричних параметрів пікселя термограми, а саме висоту за вертикаллю і горизонталлю, що визначається у сантиметрах, або умовних одиницях, а також його площу. Таким чином, знаючи площу пікселя, можна визначити загальну площу дефектних ділянок на термограмі. Обчислені параметри з двох попередніх каналів потрапляють до блока розрахунку загальної площі аномальних пікселів.

Алгоритм обчислення розмірності радіометричної сітки, що міститься в блоці обчислення загальної кількості пікселів, має наступні характеристики: кількість теплочутливих елементів болометричної матриці в двох координатах; кути розкриття оптичної системи тепловізора за горизонталлю і вертикаллю відповідно $\alpha$ і $\beta$; відстань до об'єкта контролю, що задається в сантиметрах або умовних одиницях. Алгоритм працює за наступною схемою: спочатку задається масив даних радіометричної таблиці, з наступним розрахунком кількості комірок за вертикаллю і горизонталлю, задаються кути розкриття $\alpha$ і $\beta$ і також відстань до об'єкта контролю. За допомогою формули тангенса визначається розмірність радіометричної сітки в двох координатах. Розраховується загальна площа радіометричної таблиці і площа аномальних пікселів.

Дані з лазерного далекоміра у вигляді значення відстані до об'єкта контролю у сантиметрах по-

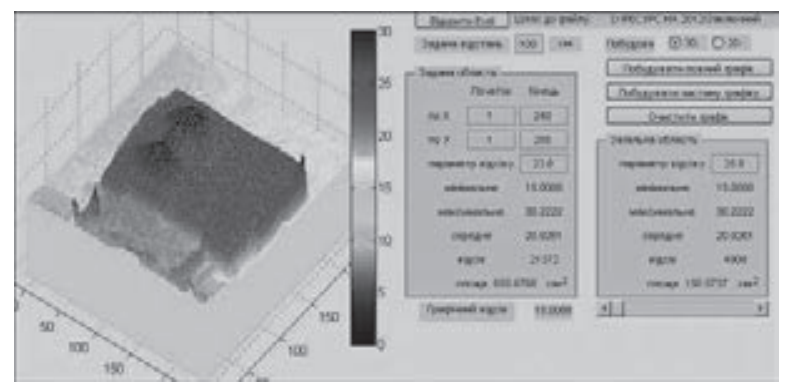

Puc. 4. Загальний вигляд програмного інтерфейсу з розрахованою площею дефекту і побудованою 3D сіткою (третя координата задана в умовних одиницях) 
трапляють до блока значення відстані до ОК. Переведені до коду програмування, дані про дистанцію контролю потрапляють до блока розрахунку загальної площі аномальних пікселів, де відбувається їх підрахунок.

Переведені у програмний код значення радіометричної таблиці надходять до блока відсіву темпера-
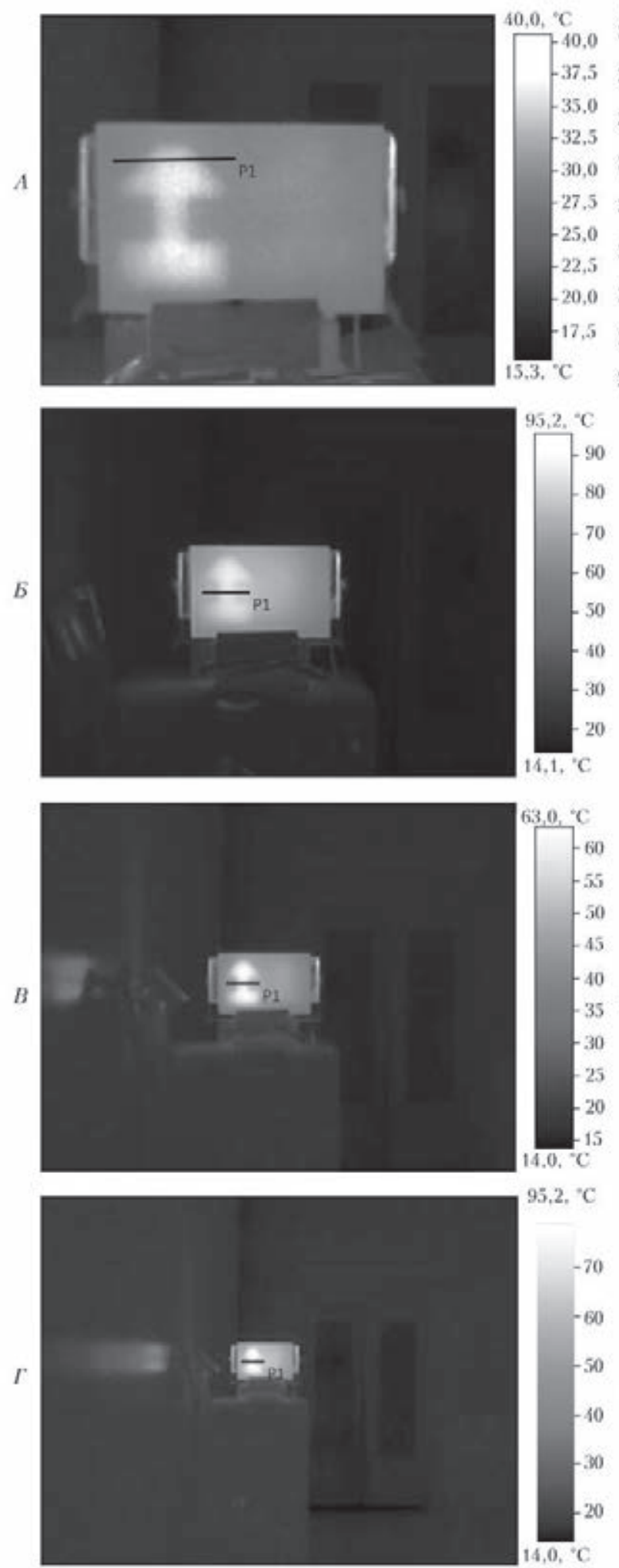

$95,2,{ }^{\circ} \mathrm{C}$

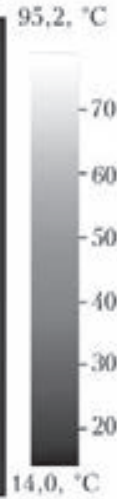

$a$ тури. Після цього оброблені дані надходять до блока графічної побудови 2D або 3D сітки розрахованих дефектів. Для коректної роботи даного блока до нього направляється інформація з блока значення відстані до ОК. Побудова відповідних сіток розрахованих дефектів має вигляд термографічних знімків, кожен піксель якого має розмірність у сантиметрах в квадраті.
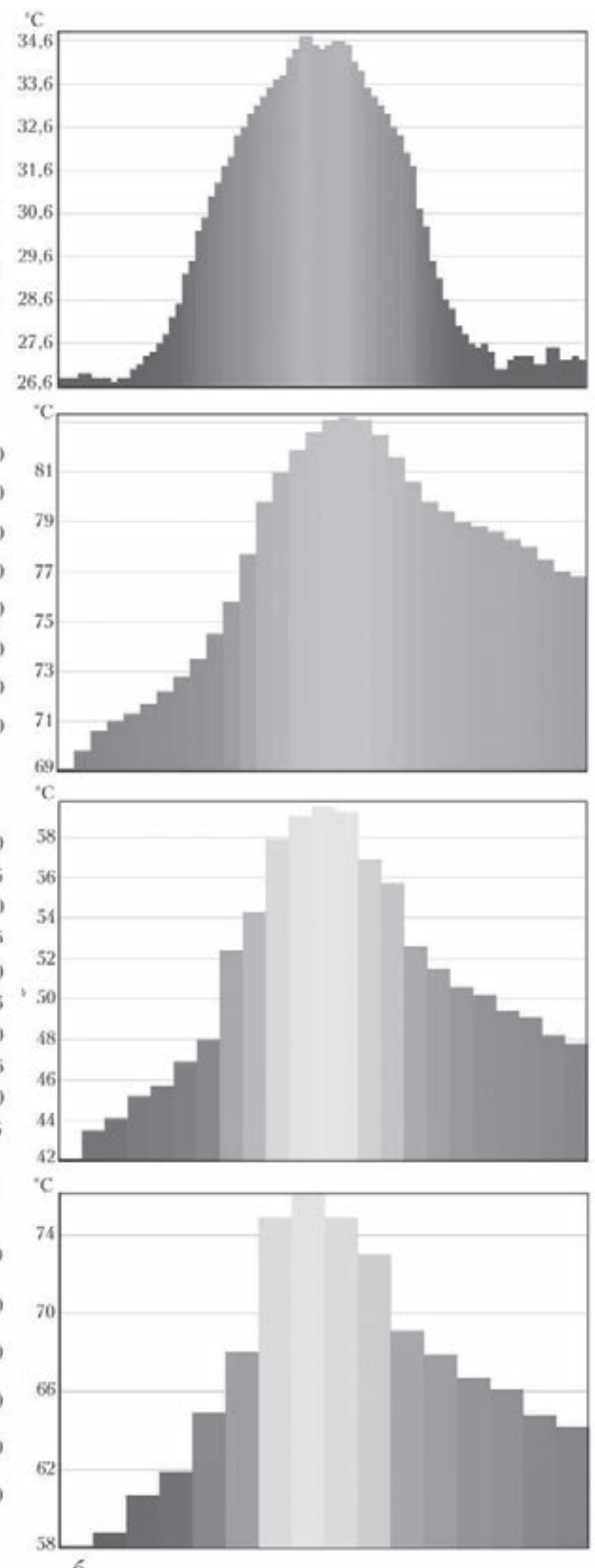

Puc. 5. Термограми пластин зі штучними дефектами складної форми $(a)$ і відповідні гістограми дефектної ділянки (б) на дистанції, м:1(A);2(Б);3(B); 5(I) 
НАУЧНО-ТЕХНИЧЕСКИЙ РАЗДЕЛ

Результати розрахунку площі виявленого дефекту в залежності від дистанції термографування

\begin{tabular}{|c|c|c|c|c|}
\hline $\begin{array}{c}\text { Дистанція } \\
\text { контролю, м }\end{array}$ & $\begin{array}{c}\text { Мінімальна температура } \\
\text { дефекту, } T^{\circ} \mathrm{C} \\
\end{array}$ & $\begin{array}{c}\text { Площа дефекту, } \\
\text { см² }^{2}\end{array}$ & $\begin{array}{c}\text { Відсоткова частка } \\
\text { дефекту, \% }\end{array}$ & $\begin{array}{c}\text { Еталонна площа } \\
\text { дефекту, см² }\end{array}$ \\
\hline 1 & 28,5 & 142,00 & 92,20 & 154 \\
\hline 2 & 73,2 & 140,78 & 91,41 & 154 \\
\hline 3 & 46,5 & 130,98 & 85,05 & 154 \\
\hline 5 & 62,8 & 127,01 & 82,24 & 154 \\
\hline
\end{tabular}

3 блоку розрахунку загальної площі аномальних пікселів та блока графічної побудови 2D або 3D сітки розрахованих дефектів оброблені дані потрапляють до блока виводу кінцевої інформації 3 наступним надходженням до програмного інтерфейсу, що зображений на рис. 3 та 4.

Необхідно зазначити, що розроблена програма може будувати і відповідно розраховувати не тільки площинні величини дефекту, тобто його площу, а й об'ємні, а саме глибину залягання і об'єм дефектної порожнини. При побудові 3D сітки (рис. 3) параметри третьої координати були задані умовно. На даному етапі розробки програмного продукту неможливо точно визначити об'ємні параметри дефекту, тобто глибину залягання дефекту і його об'єм. Для розрахунку і побудови об'ємних параметрів необхідно провести ряд відповідних експериментів задля визначення і узгодження остаточної математичної моделі і відповідних програмних блоків. Було проведено ряд експериментів із термографування пластини зі штучними дефектами складної геометричної форми на різних відстанях 3 метою визначення працездатності комплексу тепловізійної дефектометрії, його ефективності та точності розрахунку площі виявлених дефектів. Так, на рис. 5 представлені термограми об'єкта контролю та гістограми дефектних ділянок, що фіксувались на відстанях відповідно 1, 2, 3 та 5 м. Процес термографування відбувався під час динамічного нагрівання пластини від кімнатної температури до $T_{\max }$ тобто за умов нестаціонарного теплового поля.
В залежності від дистанціїі термографування розрахована площа виявленого дефекту і його відсоткова частка, що має спадний характер. Дані розрахованої площі дефекту і відповідно його відсоткової частки в залежності від дистанції термографування представлені в таблиці.

\section{Висновки}

Розроблений прилад для тепловізійної дефектометрії з відповідним програмним забезпеченням дає змогу проводити тепловізійну діагностику віддалених об'єктів і визначати геометричні параметри виявлених дефектів.

Точність розрахунку виявлених дефектів залежить від дистанції термографування і має спадний характер, при цьому точність розрахунку площі виявленого дефекту на дистанції 5 м від ОК становить 82,24 \% еталонного.

Розроблений прилад для тепловізійної дефектометрії може успішно застосовуватись для діагностики потенційно небезпечних важкодоступних об'єктів з наступним розрахунком площі виявлених дефектів.

1. Синеглазов В. М., Протасов А. Г. Повышение точности оценивания геометрических параметров дефектов тепловыми методами контроля // Техн. диагностика и неразруш. контроль. - 1992. - № 2. - С. 3-7.

2. Синеглазов В. М., Протасов А. Г. Определение теплофизических характеристик в задачах активного НК // Там же. - 1990. - № 2. - С. 73-77.

3. Протасов А. Г., Синеглазов В. М. Определение геометрических параметров дефектов тепловыми методами контроля // Там же. - 1991. - № 2. - С. 30-33.

4. Будадин O. Н., Рапопорт Д. А. Метод тепловой дефектометрии // Дефектоскопия. - 1984. - № 10. - С. 38-42.

\footnotetext{
A new approach is proposed to determine geometrical parameters of potentially difficult-of-access objects by thermovision monitoring method. Hardware, algorithm and respective software were developed for real time calculation of geometrical parameters of defects detected by thermovision method. Several experiments have been performed to determine the level of error for calculation of geometrical parameters of the detected defects. 4 References, 1 Table, 8 Figures.
}

Ke ywords: nondestructive testing, thermovision method, difficult-of-access objects

Надійшла до редакиії 02.04 .2015 


\title{
ОЦЕНКА ПАРАМЕТРА ИЗМЕНЕНИЯ ФУНКЦИОНАЛЬНОГО ТЕХНИЧЕСКОГО СОСТОЯНИЯ ПРОТИВООПОЛЗНЕВОГО АНКЕРНОГО СООРУЖЕНИЯ ПО РЕЗУЛЬТАТАМ ВИБРАЦИОННОЙ ДИАГНОСТИКИ
}

\author{
Н. И. БУРАУ' ${ }^{\text {, Э. В. КУЛИШ }}$ \\ ${ }^{1}$ НТУУ «Киевский политехнический институт». 03056, г. Киев, пр-т Победы, 37. E-mail: buray@pson.ntu.-kpi.kiev.ua \\ ${ }^{2} \mathrm{OOO}$ «Центр научно-технических услуг «Інжзахист». г. Ялта, ул. Кирова, 81.
}

\begin{abstract}
Для определения функционального технического состояния противооползневого анкерного сооружения по результатам вибрационной диагностики предложено провести оценку параметра, характеризующего изменение натяжения стержней анкера, с использованием метода максимального правдоподобия. Получены аналитические выражения оценок по двум диагностическим признакам, выполнена оценка параметра, проанализированы статистические характеристики полученных оценок. Библиогр. 6, табл. 2, рис. 2.
\end{abstract}

Ключев ве е слова: анкерные сооружения, вибрационная диагностика, натяжение стержней анкера, свайные противооползневые конструкции

Освоение оползнеопасных территорий, как правило, сопровождается угрозой возникновения оползневых смещений грунтов при производстве работ по вертикальной планировке. Для исключения образования неблагоприятных и опасных явлений на склонах предварительно выполняются сооружения инженерной защиты. В настоящее время широко используются как однотипные, так и комбинированные конструкции удерживающих сооружений [1].

Однотипные сооружения представлены свайными конструкциями, располагаемыми в один или несколько рядов, зачастую армированными по верхней грани железобетонными балками, каркасами или плитами, которые могут одновременно являться основанием для зданий и сооружений. Также к однотипным удерживающим сооружениям относятся стены с анкерным креплением к ним железобетонных плит, которые также для придания дополнительной жесткости конструкции могут армироваться железобетонными балками и каркасами.

Комбинированные удерживающие сооружения проектируются с использованием различных типов конструкций в виде комбинированных свайно-анкерных конструкций, состоящих из одного ряда свай и одного или нескольких рядов анкерных плит, прижимающих сваи или верхнюю часть свайного ростверка к склону. Иногда они выполняются в виде сложных комбинированных ростверков с использованием рядов свай, рядов свай с анкерами и рядов или отдельных плит с анкерным креплением.

Противооползневые и удерживающие сооружения позволяют компенсировать горизонталь-

() Н. И. Бурау, Э. В. Кулиш, 2015 ные нагрузки от грунтовых масс, возникающие вследствие естественных оползневых нагрузок или от нагрузок, возникающих в результате вертикальной планировки рельефа, обеспечивая нормативный запас устойчивости территории. Но при этом важным является обеспечение надежной и безопасной эксплуатации самих противооползневых сооружений. Своевременная оценка технического состояния (ТС) их элементов конструкции обеспечит поддержание противооползневых сооружений в рабочем состоянии, позволит прогнозировать возможность их дальнейшей эксплуатации или принять решение о необходимом ремонте или реконструкции.

Предыдущие работы авторов [2, 3] были посвящены разработке метода диагностики функционального технического состояния элементов конструкций противооползневых анкерных сооружений. Параметром анкерного сооружения, который характеризует изменение его состояния, является изменение натяжения стержня анкера в процессе его эксплуатации, которое недоступно измерениям. Проведенные исследования дискретных динамических моделей отдельных элементов конструкций и многоанкерных сооружений в целом показали, что выявить изменение натяжения стержня анкера можно по изменению микроперемещений, измеренных на подпорной стенке сооружения, и по изменению собственных частот стержней по первой форме колебаний. Поэтому для диагностики противооползневого анкерного сооружения предложен метод вибрационной диагностики, заключающийся в:

- периодических измерениях перемещений в заданной точке подпорной стенки (в месте установки натяжного устройства); 
- периодических измерениях отклика (при ударном воздействии в точке закрепления анкера в подпорной стенке и возбуждении свободных колебаний в стержне анкера) и определении собственной частоты контролируемого стержня;

- принятии решения о натяжении контролируемого стержня по измеренным или определенным диагностическим признакам.

Для последнего этапа целесообразно использовать методы теории оценивания для оценки параметра, который характеризует ТС контролируемого объекта. По значению полученной оценки можно судить не только о текущем состоянии объекта, но и определить начальные изменения состояния, прогнозировать дальнейшее изменение состояния даже в том случае, когда диагностические признаки еще не превысили своих пороговых значений [4].

Целью данной работы является неразрушающее оценивание изменения натяжения стержня анкера противооползневого сооружения по изменению собственной частоты стержня по первой форме колебаний и изменению микроперемещений подпорной стенки.

Метод максимального правдоподобия. Задача оценивания неизвестного параметра по результатам измерений или наблюдений некоторого процесса согласно теории оценивания содержит следующие четыре элемента [4].

Пространство параметров. Выходной величиной какого-либо источника информации является некоторый параметр $\lambda$ (переменная), который рассматривается как точка в пространстве параметров.

Вероятностное отображение из пространства параметров в пространство наблюдения. Это вероятностный закон, который описывает влияние параметра $\lambda$ на результаты наблюдения.

Пространство наблюдения. В классической задаче оценивания это пространство с конечным числом измерений. Точка в этом пространстве обозначается вектором $\mathbf{R}$.

Правило оценивания. После наблюдения $\mathbf{R}$ необходимо оценить значение параметра $\lambda$, т. е. определить оценку $\hat{\lambda}(\mathbf{R})$ неизвестного параметра $\lambda$ по результатам измерений или наблюдений. Процедура отображения пространства наблюдений в оценку называется правилом оценивания.

При описании пространства наблюдения рассматриваются случаи, когда параметр $\lambda$ является случайной величиной с соответствующей плотностью вероятности, и когда параметр $\lambda$ - это неизвестная неслучайная величина.

Для оценивания случайных параметров как правило используются байесовские оценки:

- оценка по критерию минимума среднеквадратической ошибки

$$
\int_{\Lambda}(\lambda-\hat{\lambda})^{2} W_{\text {апс }}(\lambda) d \lambda=\min ,
$$

где $\Lambda$ - интервал возможных значений параметра $\lambda ; W_{\text {апс }}(\lambda)$ - апостериорная плотность вероятности;

- оценка по критерию максимума апостериорной вероятности, по которому в качестве оценки выбирается тот корень уравнения

$$
\frac{\partial}{\partial \lambda} \ln W_{\text {апс }}(\lambda)=0,
$$

который непосредственно зависит от реализации, в которой содержится информация о параметре $\lambda$.

Для оценивания неслучайного параметра наиболее целесообразным является использование метода максимального правдоподобия (ММП). По математическому описанию такая оценка представляет собой предельный случай оценки по критерию максимума апостериорной вероятности, когда количество априорной информации стремится к нулю. Уравнение максимального правдоподобия (УМП) записывается в виде [4-6]:

$$
\frac{\partial}{\partial \lambda} \ln L(\lambda)=0,
$$

где $L(\lambda)$ - функционал правдоподобия.

В общем случае УМП представляет собой нелинейное или трансцендентное уравнение, которое может иметь несколько решений, отвечающих максимумам и минимумам функционала правдоподобия. Все решения уравнения (1) будут оценками максимального правдоподобия неизвестного параметра $\lambda$ и задача оценивания будет состоять в определении такого решения, которое отвечает максимуму максиморуму $L(\lambda)$. Оценки по максимуму правдоподобия являются асимптотически эффективными, минимальная дисперсия оценок отвечает границе Рао-Крамера и определяет потенциальную точность оценивания. В качестве меры точности оценки принимается дисперсия или среднеквадратическое отклонение полученной оценки от значения оцениваемого параметра:

$$
m\left\{\left(\hat{\lambda}_{n}-\lambda\right)^{2}\right\} \geq \sigma_{\hat{\lambda}}^{2} \geq\left[1+b_{n}^{\prime}(\lambda)\right] / I_{n}(\lambda),
$$

где $\sigma_{\hat{\lambda}}^{2}-$ дисперсия оценки; $m\{\}-$ знак математического ожидания; $b_{n}^{\prime}(\lambda)-$ производная по параметру $\lambda$ от величины смещения полученной оценки от значения оцениваемого параметра; $I_{n}(\lambda)$ - информация по Фишеру, содержащаяся в выборке длиной $n$ и определяемая выражением:

$$
I_{n}(\lambda)=m\left\{\left[\frac{\partial}{\partial \lambda} \ln L(\lambda)\right]^{2}\right\} .
$$

Для разработки правила и алгоритма оценивания изменения натяжения стержней противооползневого анкерного сооружения по результатам 
вибрационной диагностики будем использовать метод максимального правдоподобия. Для получения аналитических выражений оценок используем результаты модельных экспериментов, полученные в работах $[2,3]$. В качестве оцениваемого параметра рассматриваем параметр $\Delta C$, который при моделировании использовался для описания уменьшения натяжения стержня анкера. В соответствии с изложенным выше описанием ММП в задаче оценивания обозначим $\Delta C=\lambda$.

Оценивание параметра изменения натяжения стержня анкера по изменению собственной частоты по первой форме колебаний стержня. Для оценивания параметра $\lambda$ по изменению собственной частоты стержня по первой форме колебаний используем данные моделирования многоанкерного противооползневого сооружения, приведенные в работе [3] в табл. 4 для $i=1$. График изменения приведенной собственной частоты от оцениваемого параметра приведен на рис. 1, где $f_{0}$ - значение собственной частоты по первой форме колебаний для случая закрепленных замков и одинаковой жесткости всех стержней $(\Delta C=0)$, $f_{1 *}-$ значение собственной частоты по первой форме колебаний при уменьшении жесткости одного анкера $(\Delta C=0,15 ; 0,25)$.

Для аппроксимации приведенной кривой используем полином второго порядка:

$$
m_{f}=\mu_{f 0}+\mu_{f 1} \lambda+\mu_{f 2} \lambda^{2},
$$

значения коэффициентов полинома: $\mu_{f 0}=1 ; \mu_{f 1}=-0,42$; $\mu_{f 2}=-9,2$.

Полагаем, что при проведении вибрационных измерений в реальных условиях действуют неконтролируемые помехи, в результате чего определенные отношения частот $f_{1 *} / f_{0}$ при $i$-м измерении будем считать случайной величиной $\xi_{\text {if }}$ (индекс $f$ означает, что для диагностики используется частотный признак) с нормальным законом распределения:

$$
p\left(\xi_{i f}\right)=\frac{1}{\sigma_{f} \sqrt{2 \pi}} \exp \left[-\frac{\left(\xi_{i f}-m_{f}\right)^{2}}{2 \sigma_{f}^{2}}\right],
$$

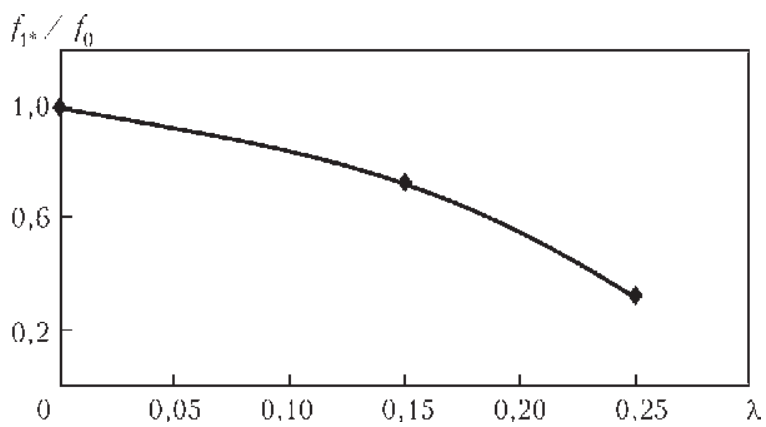

$P u c$. 1. График зависимости приведенной собственной частоты стержня многоанкерного противооползневого сооружения по первой форме колебаний от параметра $\lambda$ где $m_{f}$ - математическое ожидание случайной величины, которое имеет вид (2); $\sigma_{f}$ - среднеквадратическое отклонение, которое не зависит от параметра $\lambda$.

Запишем функцию правдоподобия для $i$-го измерения случайной величины $\xi_{i f}$ :

$$
\ln p\left(\xi_{i f}, \lambda\right)=-\ln \sigma_{f}-0,5 \ln 2 \pi-\frac{\left(\xi_{i f}-m_{f}\right)^{2}}{2 \sigma_{f}^{2}}
$$

или для случая $n$ измерений:

$$
\begin{aligned}
L\left(\xi_{f}, \lambda\right)= & \sum_{i=1}^{n} \ln p\left(\xi_{i f}, \lambda\right)=-n\left(\ln \sigma_{r}+0,5 \ln 2 \pi\right)- \\
& -\frac{1}{2 \sigma_{f}^{2}} \sum_{i=1}^{n}\left(\xi_{i f}^{2}-2 \xi_{i f} m_{f}+m_{f}^{2}\right) .
\end{aligned}
$$

После математических преобразований УМП (1) для функции (3) получим в виде:

$$
\frac{1}{\sigma_{f}^{2}}\left(n m_{f} \frac{\partial m_{f}}{\partial \lambda}-\sum_{i=1}^{n} \xi_{i f} \frac{\partial m_{f}}{\partial \lambda}\right)=0 .
$$

С учетом (2) уравнение (4) преобразуем к виду:

$$
\sum_{j=0}^{3} \mathrm{M}_{f j} \lambda^{j}=0
$$

где $\mathrm{M}_{f 3}=2 \mu_{f 2}^{2} ; \mathrm{M}_{f 2}=3 \mu_{f 1} \mu_{f 2}$;

$$
\begin{gathered}
M_{f 1}=2 \mu_{f 0} \mu_{f 2}+\mu_{f 1}^{2}-2 \mu_{f 2} \sum_{i=1}^{n} \xi_{i f} ; \\
M_{f 0}=\mu_{f 1}\left(\mu_{f 0}-\sum_{i=1}^{n} \xi_{i f}\right) .
\end{gathered}
$$

Для определения из уравнения (5) оценки параметра $\lambda$ используем результаты трех модельных экспериментов $(i=3)$. Результаты определения оценок и их статистических характеристик $m_{\hat{\lambda}}$ и $\sigma_{\hat{\lambda}}$ с учетом измерительного шума приведены в табл. 1 .

Как видно из приведенны результатов, среднеквадратическое отклонение полученных оценок имеет один порядок, за исключением случая для $\lambda=0,3$, где существует ограничение метода моделирования.

Для определения качества полученных оценок используем статистический показатель качества оценки Q, который определяется по формуле [6]:

$$
Q(\lambda)=\frac{\sigma_{\hat{\lambda}}^{2}}{m_{\hat{\lambda}}^{2}}
$$

Показатель (6) является обратным отношением сигнал/шум, а значения $Q<<1$ соответствуют устойчивым оценкам. Как видно из приведенных в последних двух строках табл. 1 данных, полученные оценки удовлетворяют требованию статистического качества и являются устойчивыми и эффективными. 
ПРОИЗВОДСТВЕННЫЙ РАЗДЕЛ

T а б л и ц а 1 . Значения и статистические характеристики оценок параметра $\lambda$ по частотному признаку

\begin{tabular}{|c|c|c|c|c|c|}
\hline \hline Номер измерения & $\lambda=0,1$ & $\lambda=0,15$ & $\lambda=0,2$ & $\lambda=0,25$ & $\lambda=0,3$ \\
\hline$i=1$ & 0,0999 & 0,1499 & 0,2 & 0,25 & 0,2999 \\
\hline$i=2$ & 0,0988 & 0,1507 & 0,2006 & 0,249 & 0,3073 \\
\hline$i=3$ & 0,0996 & 0,1491 & 0,1993 & 0,2491 & 0,2995 \\
\hline$m_{\hat{\lambda}}$ & 0,0994 & 0,1499 & 0,1999 & 0,2494 & 0,3022 \\
\hline$\sigma_{\hat{\lambda}}$ & $2,1 \cdot 10^{-4}$ & $4,8 \cdot 10^{-4}$ & $2,8 \cdot 10^{-4}$ & $2,1 \cdot 10^{-4}$ & $1,28 \cdot 10^{-3}$ \\
\hline
\end{tabular}

Т а б л и ц а 2 . Значения и статистические характеристики оценок параметра $\lambda$ по признаку $\Delta D$

\begin{tabular}{|c|c|c|c|c|c|}
\hline Номер измерения & $\lambda=0,1$ & $\lambda=0,15$ & $\lambda=0,2$ & $\lambda=0,25$ & $\lambda=0,3$ \\
\hline$i=1$ & 0,1717 & 0,1987 & 0,1998 & 0,249 & 0,2999 \\
\hline$i=2$ & 0,1719 & 0,1979 & 0,2 & 0,2489 & 0,3 \\
\hline$i=3$ & 0,1718 & 0,1990 & 0,2 & 0,2494 & 0,3 \\
\hline$m_{\hat{\lambda}}$ & 0,1718 & 0,1985 & 0,1999 & 0,2491 & 0,29996 \\
\hline$\sigma_{\hat{\lambda}}$ & $6,7 \cdot 10^{-5}$ & $2,6 \cdot 10^{-4}$ & $1 \cdot 10^{-4}$ & $4,6 \cdot 10^{-4}$ & $2,2 \cdot 10^{-5}$ \\
\hline
\end{tabular}

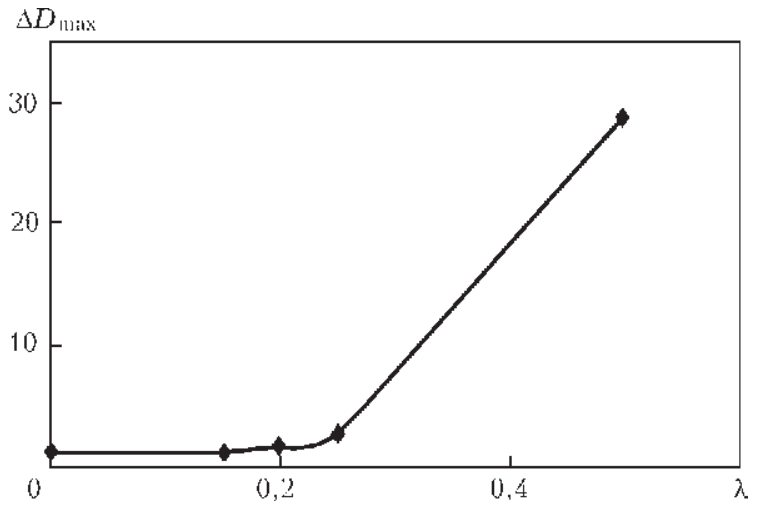

Рис. 2. График зависимости относительного перемещения подпорной стенки многоанкерного противооползневого сооружения от параметра $\lambda$

Оценивание параметра изменения натяжения стержня анкера по изменению микроперемещений подпорной стенки. Для оценивания параметра $\lambda$ по данному признаку используем приведенные в работе [2] в табл. 3 результаты изменения относительного значения максимального перемещения $\Delta D_{\max }$ подпорной стенки в зависимости от значения параметра, характеризующего изменение натяжения стержня анкера. График зависимости данного признака от оцениваемого параметра представлен на рис. 2.

Как и в предыдущем случае, для данной аппроксимации кривой используем полином второго порядка от параметра $\lambda$ :

$$
m_{\Delta D}=\mu_{\Delta D 0}+\mu_{\Delta D 1} \lambda+\mu_{\Delta D 2} \lambda^{2},
$$

значения коэффициентов полинома: $\mu_{\Delta D 0}=1 ; \mu_{\Delta D 1}=$ $=-42,56 ; \mu_{\Delta D 2}=196,8$.

Так как полином (7) имеет такой же порядок, как и (2), воспользуемся полученными выше аналитическими выражениями (3)-(5) для определения оценки параметра $\lambda$ по данному диагностическому признаку. Результаты определения оценок и их статистических характеристик приведены в табл. 2.
Как видно из полученных результатов, значения дисперсии оценок находятся практически в одном диапазоне. Определение статистического показателя качества полученных оценок по выражению (6) и его анализ показал, что оценивание параметра $\lambda$ по изменению перемещений подпорной стенки является эффективным и устойчивым, так как во всем рассматриваемом диапазоне значений $\lambda$ статистический показатель качества $Q<<1$.

\section{Выводы}

Для диагностики противооползневого анкерного сооружения предложен метод вибрационной диагностики, который позволяет определить изменение натяжения стержня анкера по изменению микроперемещений, измеренных на подпорной стенке сооружения, и по изменению собственных частот стержней по первой форме колебаний.

Разработано правило и алгоритм оценивания изменения натяжения стержней противооползневого анкерного сооружения по результатам вибрационной диагностики с использованием метода максимального правдоподобия. Выполнено оценивание параметра изменения натяжения стержня анкера многоанкерного сооружения, определены статистические характеристики полученных оценок, анализ которых показал эффективность и устойчивость оценок по статистическому показателю качества.

Полученные оценки изменения натяжения стержней целесообразно использовать для определения текущего функционального технического состояния стержней и прогнозирования изменения их состояния в процессе эксплуатации противооползневых анкерных сооружений.

1. Билеуш А. И. Оползни и противооползневые мероприятия. - Киев: Наук. думка, 2009. - 560 с.

2. Бурау Н. И., Кльофа Ю. В., Кулиш Э. В. Разработка метода диагностики функционального технического состояния элементов конструкций противооползневых 
анкерных сооружений. Сообщение 1. Анализ напряженно-деформированного состояния и собственных частот анкера // Техн. диагностика и неразруш. контроль. -2011 . - № 2. - C. 40-45.

3. Бурау Н. И. Разработка метода диагностики функционального технического состояния элементов конструкций противооползневых анкерных сооружений. Сообщение 2. Анализ собственных форм и частот сложной конструкции противооползневого анкерного соружения / Н.И. Бурау, Ю.В. Кльофа, Э.В. Кулиш // Там же. -2011. - № 3. - C. 40-43.

4. Ван Трис Г. Теория обнаружения, оценок и модуляции.

T. 1. Теория обнаружения, оценок и линейной модуля- ции: Пер с англ. / Под ред. В.И. Тихонова. - М.: Сов. радио, 1972. - 744 с.

5. Левин Б.Р. Теоретические основы статистической радиотехники. В 3-х кн. Кн. 2 / Изд. 2-е, перераб. и допол. - М.: Сов. радио, $1975 .-392$ с.

6. Бурау Н. И., Игнатович С. Р. Оценивание параметра трещиноподобного повреждения лопаток в процессе виброакустического диагностирования газотурбинных двигателей // Надійність і довговічність машин і споруд: Міжнар. наук.-техн. зб. - Київ: ІПМ, 2008. - Вип. 30. C. $32-40$

The non-destructive evaluation of the parameter of changing of a tension condition an anchor is proposed for the determination a current condition of the anchor against landslide construction by using the the generalized likelihood method. The analytical dependencies of estimations are obtained for the two features, the evaluation is carried out, the statistical characteristics of the estimations are analyzed.

Ke ywords : anchor constructions, vibration diagnostics, anchor rod tensions, anti-slide pile structures

Поступила в редакиию 26.12.2014

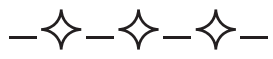

\section{ЗАСІДАННЯ ТЕХНІЧНОГО КОМІТЕТУ ЗІ СТАНДАРТИЗАЦІї ТК-78}

14 травня 2015 р. відбулося засідання ТК-78 «Технічна діагностика та неруйнівний контроль», що опікується питаннями гармонізації стандартів у сфері неруйнівного контролю та технічної діагности в Україні. Участь у засіданні взяли представники наукових, освітніх, промислових підприємств і організацій, що працюють у сфері неруйнівного контролю, зокрема, IE3 ім. С.О. Патона, НТУУ «Київський політехнічний інститут», ТК «Спецмонтаж», ПрАТ «ВТП «Укренергочормет», АТ «Одеський припортовий завод», ТОВ «Придніпровський АЦНК і ТД», ТОВ «НВФ «Діагностичні прилади» та інші. Особлива увага учасників була присвячена припиненню до кінця поточного року дії на території України стандартів СРСР, що передбачено Програмою діяльності Кабінету міністрів України.

Для досягнення зазначеної мети національний орган по стандартизації повинен у поточному 2015 р. скасувати всі діючі в Україні стандарти СРСР (ГОСТ), розроблені до 1992 р. В сферу відповідальності ТК-78 увійшло 40 стандартів ГОСТ, які підлягають скасуванню. Отже, необхідно їх переглянути і замінити на відповідні національні, а у разі їх відсутності, на міжнародні або європейські стандарти.

На думку учасників, основна проблема скасування ГОСТ і переходу на міжнародні стандарти полягає у відмінності структур міжнародної і національної систем стандартизації. Зокрема, для системи міжнародних європейських стандартів в галузі неруйнівного контролю притаманна спеціалізація на конкретних напрямках, як то: технологія методу (способу), вимоги до дефектоскопічного обладнання, контрольних зразків, дефектоскопічних матеріалів, критеріїв приймання тощо. Тоді як стандарти, особливо ГОСТ, поєднують у собі всі ці вимоги для пев-

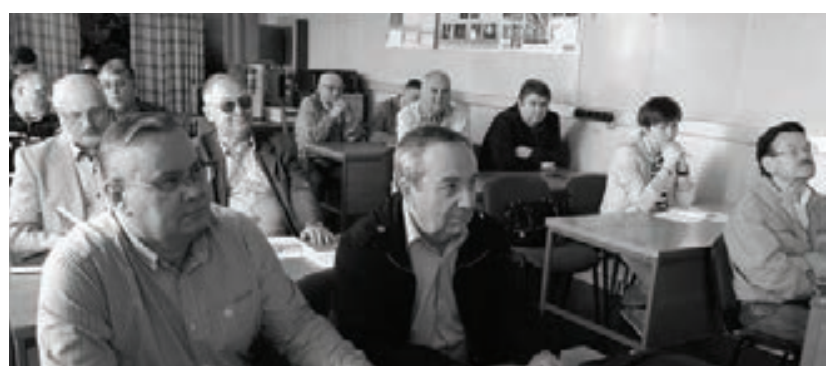

ного методу НК. Тому потрібно застосувати комплексний підхід, який передбачає, що замість одного стандарту ГОСТ потрібно ввести відразу кілька стандартів EN чи ISO, які відповідно встановлюють загальні вимоги до технології, апаратури, дефектоскопічних засобів, критеріїв приймання тощо. Заступник голови ТК-78 проф. Троїцький В.О., який очолює напрямок «Неруйнівний контроль», зазначив, що Технічний комітет підтримує тісні контакти з ISO/TC-135 «Неруйнівний контроль», а його керівник Хаджиме Катано відвідав Україну з візитом, у ході якого виступив з доповіддю на семінарі, організованому IE3 ім. Є.О. Патона НАН України.

Підводячи підсумки, В.О. Троїцький зазначив, що Технічний комітет активно бере участь у діяльності Міжнародної організації із стандартизації з усіх методів неруйнівного контролю і має і надалі відігравати провідну роль у гармонізації національної системи стандартизації з міжнародною та європейською. Він запропонував створити робочу групу для перегляду ГОСТ, що підлягають скасуванню, та підготовки пропозицій щодо їх адекватної заміни на відповідні національні та міжнародні стандарти, які будуть передані до національного органу стандартизації.

Щупак С. О., IE3 ім. С. О. Патона НАН Украӥни 


\title{
КОНТРОЛЬ ГЕРМЕТИЧНОСТИ ЗАКУПОРЕННЫХ КОНСЕРВНЫХ БАНОК ПРИ ПЕРЕРАБОТКЕ СЕЛЬСКОХОЗЯЙСТВЕННОЙ ПРОДУКЦИИ
}

\author{
И. П. ЗАВАЛЬНЮК \\ Херсон. гос. аграрный ун-т. 73006, г. Херсон, ул. Розы Люксембург, 23. E-mail: office@ksau.knherson.ua
}

\begin{abstract}
Проанализированы методы контроля герметичности закупоренных консервных банок. Особое внимание направлено на развитие основных методов контроля герметичности в патентных материалах. Установлены функциональные особенности и требования к эффективной автоматизированной системе контроля герметичности.
\end{abstract}

Ключе в ы е слов в : герметичность, операции закатки, неразрушаюший контроль, визуальный метод, пузырьковый метод, манометрический метод, автоматизированная установка контроля герметичности

$\mathrm{B}$ соответствии с технологией переработки сельскохозяйственной продукции консервы - это герметически укупоренные и стерилизованные продукты растительного или животного происхождения, уложенные в жестяную или стеклянную тару и предназначенные для длительного хранения. Консервная тара должна быть герметичной, коррозионностойкой, гигиеничной, иметь высокие теплопроводность и теплостойкость, прочность при минимальной массе и стоимости, что обеспечит длительное сохранение доброкачественности продукта.

Перед использованием консервные банки проверяют на герметичность мокрым и сухим методами. Более целесообразен сухой метод проверки на специальных машинах-тестерах, в которых в банке создается избыточное давление или вакуум. Негерметичные банки отбраковывают и направляют на подпайку. Стеклянную тару просматривают, отбирают бой, тару с трещинами, щербинами, стрелками на дне, переворачивают вверх дном и затем в течение $2 \ldots 3$ с воздействуют сжатым воздухом для выдувания стеклянной пыли и мелких осколков, прилипших к стенкам тары.

В консервированных изделиях могут содержаться микроорганизмы - бактерии, дрожжи и плесени, которые попадают в консервные банки и после стерилизации, проникая внутрь в негерметичных местах.

Причинами негерметичности банок являются:

- плохое качество закаточного шва, как следствие недостаточной отрегулированности закаточной машины;

- отклонения в линейных размерах банок, поступающих на закатку;

- перекосы в фиксировании банок в ячейках контроля;

- изнашивание герметизирующих прокладок.

(С) И. П. Завальнюк, 2015
Чтобы избежать брака и порчи консервов, потери пищевой продукции, возникающих из-за нарушения целостности упаковки, низкого качества герметизации, необходимо контролировать герметичность упаковок. Для этой цели принято применять методы НК.

Рациональный метод контроля герметичности, а также применяемую установку можно выбрать исходя из требований к необходимой производительности, надежности контроля, экономической рентабельности, безопасности, условий контроля и т.п.

Целью работы является анализ особенностей методов НК и функциональных возможностей установок контроля герметичности закупоренных консервных банок, используемых в пищевых технологиях в настоящее время.

Материалы и результаты исследований. В соответствии с концепцией НК [1], герметичность малогабаритных изделий в замкнутой оболочке массового производства, которыми и являются закупоренные консервные банки, должна контролироваться в ритме производства, а установки для контроля герметичности, являющиеся частью комплекса технологического оборудования, должны быть высокопроизводительными, автоматизированными и обеспечивать надежную отбраковку негерметичных изделий.

Основные функции автоматизированных установок контроля герметичности (АУКГ) состоят в $100 \%$-ном или выборочном контроле изделий на герметичность и выбраковке изделий, не соответствующих требованиям технических условий по степени герметичности.

Функциональная схема типовой АУКГ показана на рис. 1. Определяющими блоками АУКГ являются испытательный блок 2 и блок преобразования величины утечки 5 , который формирует однозначно зависимый от величины утечки сигнал, используемый в дальнейшем для обработки 


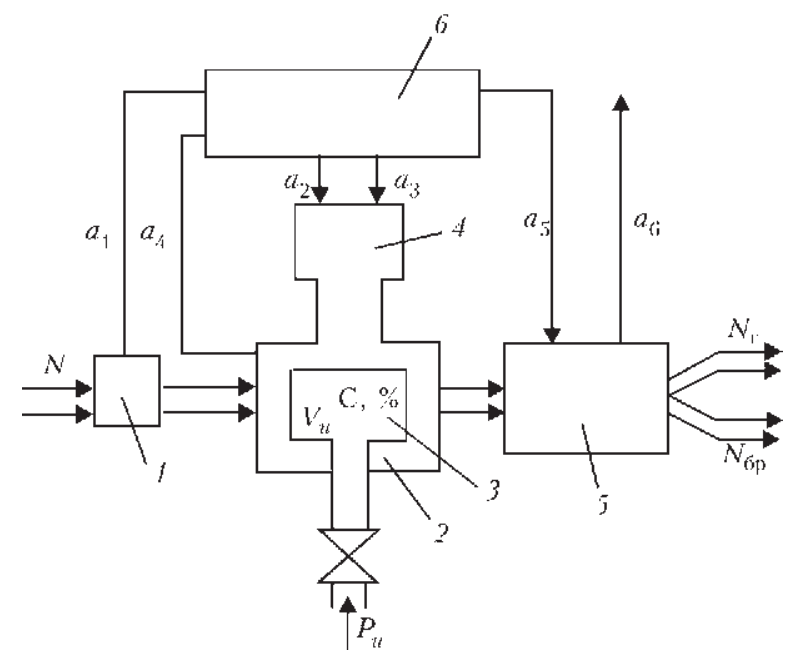

Puc. 1. Функциональная схема АУКГ: 1 - узел подачи изделий на испытательную позицию для их фиксации и герметизации; 2 - испытательный блок; 3 - контролируемый объект; 4 - блок разбраковки изделий по результатам контроля; 5 блок первичного преобразования величины утечки; 6 - микропроцессорный контроллер

информации и воздействия на дополнительные органы. Взаимосвязь работы всех блоков обеспечивается микропроцессорным контроллером 6 , в состав которого входит в ряде случаев блок обработки информации, в том числе система компенсации фонового сигнала.

По результатам проверки изделий на герметичность их общее количество $N$ распределяется на две группы: годные $N_{\text {г }}$ и негерметичные $N_{\delta р}$. Механическая связь между блоками показана двойными линиями, электрическая - линиями $a_{1}-a_{6}$.

В производственных условиях герметичность банок, закатанных на любом типе машин, исключая вакуум-закаточные, после закатки проверяют методами [2], характеристика которых представлены в таблице.

Согласно данным, приведенным в [2], качество работы закаточных машин проверяют не менее, чем три раза за смену для каждой пары роликов. Если в течение часа проверки количество негерметичных банок превышает $0,1 \%$, то закаточную машину останавливают и переналаживают закаточный механизм.

Следовательно, на перерабатывающих предприятиях предусмотрен не сколько прямой контроль готовой герметизированной продукции, но и мониторинг качественной работы технологического оборудования для ее производства.

Анализ описанных методов контроля герметичности показывает, что в производственных условиях широко используется ручной труд, визуальная оценка герметичности, операция контроля длится значительное время по сравнению с высокими и постоянно растущими темпами работы консервных линий. Рассмотренные методы получили развитие благодаря современным достижениям в области НК.

\section{Производственные методы контроля герметичности}

1. Визуальный: герметичность контролируют путем внешнего осмотра закаточного шва, проводимого оператором непосредственно у конвейера. В жестяной таре можно выявить - пробоины, сквозные трещины, деформацию корпуса, некачественный продольный шов, вмятины на закаточном шве; в стеклянной - перекос крышек, трещины или скол стекла у закаточного шва, неполную посадку крышек относительно горловины банок.

Недостаток: обнаруживается только видимый брак.

2. Пузырьковый воздушный: контроль происходит в течение $50 \ldots 60$ с при движении банок в водяной ванне, окрашенной внутри белой краской, хорошо освещенной и наполненной горячей водой $\left(80 \ldots 90{ }^{\circ} \mathrm{C}\right)$. Вследствие расширения воздуха под действием нагревания у плохо герметизированных банок появляются воздушные пузырьки. Производительность около 8000 банок в час. Возможность метода ограничивается конструкцией, формой и материалом изделия, помещаемого в емкость с водой. Порог чувствительности $1,3 \cdot 10^{-6} \mathrm{M}^{3} \cdot$ Па/с.

Недостатки: 1) невозможно обнаружить мельчайшие отверстия из-за незначительного давления воздуха, создаваемого внутри банок во время прогрева в ванне; 2) плохо выявявляются мелкие отверстия, находящиеся в закаточном шве на стыке с продольным швом сборной консервной банки или в самом шве.

Пузырьковый эфирный: метод используется в основном для проверки надежности закаточных машин. Герметичность швов проверяют по появлению пузырьков воздуха и паров эфира в водяной контрольной ванне, нагретой до $80 \ldots 85^{\circ} \mathrm{C}$. Серный эфир в количестве 5, 6 капель вводится в банку перед заполнением. Порог чувствительности $1,3 \cdot 10^{-6} \mathrm{M}^{3} \cdot$ Па/с.

Недостаток: применение серного эфира на предприятиях пищевой промышленности влечет нарушение санитарно-технической безопасности производства и работающего персонала.

3. Манометрический: метод является более совершенным и точным. Наличие течей определяют по показаниям манометров, фиксирующих изменение величины давления контрольной воздушной среды в камере с контролируемой банкой в течение некоторого промежутка времени. По данному принципу построены вертикальные или горизонтальные воздушные и воздушно-водяные тестеры, состоящие из камер контроля банок, соединенных с вакуум-насосами или компрессорами. Такие тестеры - высокопроизводительные автоматы, позволяющие контролировать $100 \ldots 120$ банок в мин. Метод накладывает жесткие требования к стабильности и равенству температуры окружающей среды и температуры самого изделия, что весьма трудно обеспечить в производственных условиях. Порог чувствительности $1,3 \cdot 10^{-6} \mathrm{M}^{3} \cdot$ Па/ $\mathrm{c}$.

Недостатки: 1) метод позволяет выявлять замкнутые изделия с микроскопическими дефектами и не позволяет - с более крупными; 2) существует вероятность получения ошибочного результата, поскольку при контроле негерметичного изделия в нем также повысится давление, причем до заданной величины и в процессе контрольной выдержки изменения давления в камере не произойдет. 
Заслуживают внимание следующие патентные материалы.

Автором патента [3] развит пузырьковый метод контроля герметичности и предложен комплекс автоматизированного контроля герметичности консервных банок. Предлагаемая установка содержит ванну с жидкостью, конический рабочий элемент, расположенный в жидкости, источник освещения, фотореле с фотоприемником и манипулятор. Манипулятор оборудован захватом, выполненным в виде подвижных конических клещевых элементов с боковыми пластинами, и содержит приводы конических элементов захвата. Фотореле предназначено для управления указанными приводами. В ванне с жидкостью установлено термореле, выходной сигнал которого используется для управления исполнительным устройством, обеспечивающим регулирование подачи пара в ванну с целью поддержания требуемой температуры жидкости.

Манометрический метод контроля совершенствуется автором работы [4], целью которого было создание достоверного неразрушающего способа контроля герметичности укупоренных изделий, использующего результаты измерений давления в камере. Эта цель достигается тем, что в герметичную камеру (рис. 2) с укупоренным изделием подают или откачивают из нее строго определенное количество газа.

О герметичности делают вывод путем сравнения давления в камере с его контрольным значением, которое предварительно определяют при тех же условиях путем измерения давления в камере при установке в нее эталонного изделия.

Однако в данной работе не рассматривается возможность автоматизации контроля герметичности, что предусмотрено в изобретении [5]. Предложенный способ контроля герметичности металлических банок с пищевыми продуктами включает нагревание банки с продуктом до температуры $85 \pm 2{ }^{\circ} \mathrm{C}$ и индикацию локальных выделений на закаточных швах. Причем индикация осуществляется по неоднородности цвета поверхности банки с помощью системы технического зрения. При этом видеосъемка движущейся банки проводится одновременно с двух сторон поворачивающимися вокруг своей оси видеокамерами (рис. 3).

На основании обработки полученной видеоинформации автоматически производится отбраковка банки с помощью соответствующей подсистемы, которая обеспечивает удаление с помощью толкателя дефектных банок с транспортера в накопитель. Подсистема сигнализации информирует оператора световым и звуковым сигналами о наличии и количестве бракованных банок.

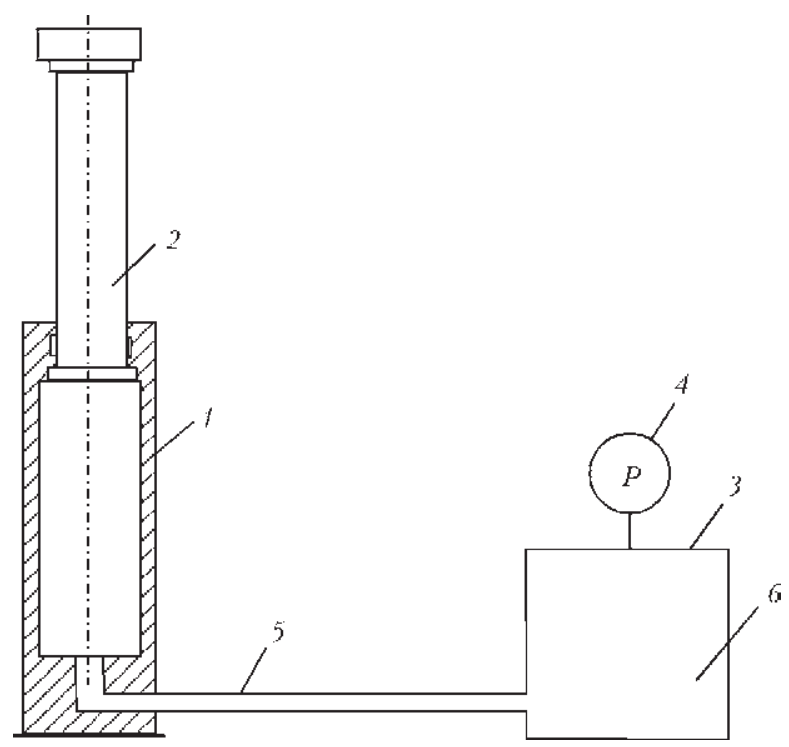

Puc. 2. Схема установки для реализации манометрического способа контроля: 1 - цилиндр; 2 - поршень; 3 - герметичная камера; 4 - манометр; 5 - шланг; сообщающий подпоршневую полость цилиндра с камерой; 6 - укупоренное изделие

Пример использования системы контроля герметичности на основе средств технического зрения при производстве пищевых консервов описан в патенте на полезную модель [6]. Предложенный вариант линии для производства рыбных консервов позволяет заменить выборочный ручной контроль герметичности банок автоматическим контролем всех банок. При этом практически исключается пропуск невыявленных негерметичных

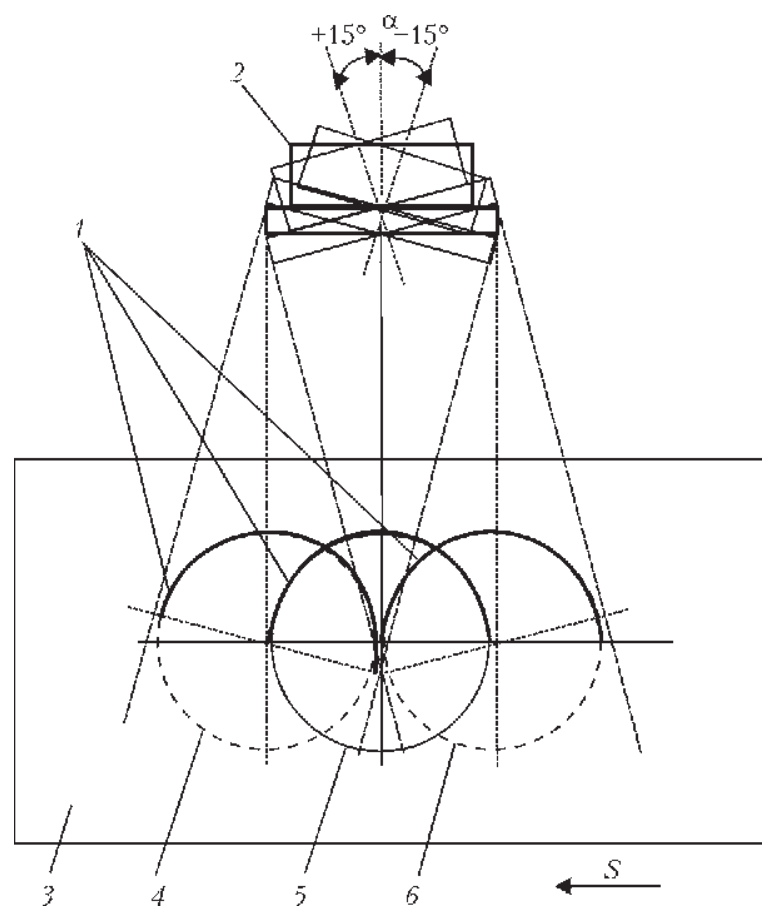

Puc. 3. Схема изменения взаимного положения видеокамеры и контролируемой банки: 1 - контролируемая поверхность банки; 2 - видеокамера; 3 - ленточный транспортер; 4 - конечная позиция банки в цикле видеосъемки; 5 - средняя позиция банки в цикле видеосъемки; 6 - начальная позиция банки в цикле видеосъемки; $\alpha$ - угол поворота видеокамеры; $S$ - направление движения ленточного транспортера 
банок ввиду того, что предварительно создают условия для протечек на банках, используя вакуумирование автоклава, что создает необходимый перепад давления, вызывающий протечки, легко обнаруживаемые системой технического зрения.

\section{Вывод}

Представленные патентно-информационные материалы показали, что задачей дальнейших исследований является совершенствование существующих методов контроля герметичности закупоренных консервных банок с целью создания эффективной автоматизированной системы контроля герметичности, которая:

1) позволила бы минимизировать недостатки, повысить точность существующих методов контроля герметичности и исключить влияние человеческого фактора на результат контроля;

2) должна быть неотьемлемой частью технологической линии производства консервов, поскольку продолжительность процесса с момента закатки до начала стерилизации не должна превышать 30 мин;
3) обладала бы возможностью функционирования в специфических условиях консервного производства - высокая температура, влажность, зажиренность - в случае производства мясных консервов.

1. Неразрушающий контроль: Справ.: В 7 т. - Т.2: В 2 кн. - М.: Машиностроение, 2003. - 688 с. - Кн. 1: Контроль герметичности / А.И. Евлампиев, Е.Д. Попов, С.Г. Сажин и др.

2. Інструкиія про порядок санітарно-технічного контролю консервів на виробничих підприємствах, оптових базах, в роздрібній торгівлі та на підприємствах громадського харчування I 4.4.4.077-2001/ Затв. 07.11.2001 № 40. - 43 с.

3. Пат. 47139 Украйна, МПК G01M 3/06. Комплекс автоматизованого контролю герметичності консервних банок / I.M. Ощипок. - № 2001085545; Опубл. 17.06.2002, Бюл. № 6 .

4. Пат. 2245530 РФ, МПК G01M 3/00. Способ контроля герметичности укупоренных изделий / А.Н. Ракшин, С.С. Сергеев. - № 2003101685/28; Опубл. 27.01.2005, Бюл. № 3.

5. Пат. 2396529 РФ, МПК G01M 3/00. Способ контроля герметичности металлических банок с пищевыми продуктами и устройство для его осуществления / Н.А. Долгий, С.П. Сердобинцев. - № 2009128944/28; Опубл. 10.08.2010, Бюл. №22.

6. Пат. 127589 РФ, МПК А22C 29/00, А23L3/00. Линия для производства рыбных консервов / Н.А. Долгий. № 2012136523; Опубл. 10.05.2013, Бюл. № 20.

In article is noted urgency to hermeticities occluded tin bank for provision of long keeping to agricultural product. Analyzed essence and defect of the production methods of the checking to hermeticities occluded tin bank. Attention is accented on development of the main methods of the checking to hermeticities in patent material. Functional particularities and requirements to efficient automated systems of the checking to hermeticities will installed.

Key wo rds : sealing, sealing operation, nondestructive testing, visual method, bubble method, manometric method, automated setting of sealing control

Поступила в редакцию 05.10 .2014

\section{НОВА КНИГА}

\section{УДК $621.83 / 85+529.4$}

3. Т. Назарчук, В. Р. Скальський, С. П. Почапський. Технології відбору та опрацювання низькоенергетичних діагностичних сигналів. / - Київ: Наук. думка, 2014. - 304 с.

У монографії викладено методологічні основі відбору та опрацювання низькоенергетичних емісійних сигналів, які генеруються під час руйнування твердих тіл. Вони побудовані на розроблених нових теоретичних підходах до ідентифікування таких сигналів на фоні завад, які існують в умовах технічного діагностування

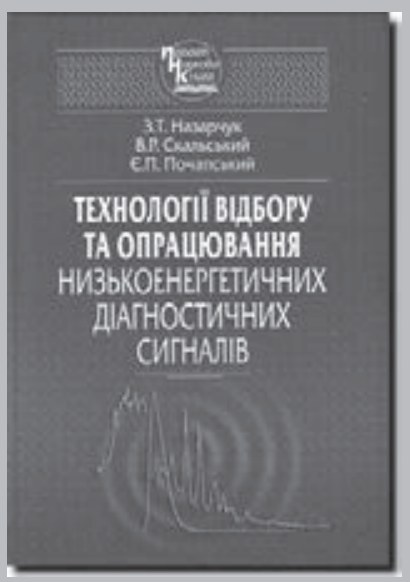
елементів конструкцій. Запропоновано також нові алгоритми відбору та опрацювання сигналів, що дозволили суттєво скоротити обсяги пам'яті оперативно-запам’ятовуючих пристроїв вимірювальних діагностичних систем.

Створене алгоритмічно-програмне забезпечення використано для побудови сучасних технічних засобів оцінки ранніх стадій зародження та розвитку руйнування різних конструкційних матеріалів. Їх структурні схеми і принципи функціонування приведені у монографії. Практичне використання розробок показало високу ефективність проведення діагностичних робіт на реальному обладнанні та елементах конструкцій тривалого експлуатування.

Для наукових співробітників, інженерів-дослідників, аспірантів, студентів вищих навчальних закладів спеціальностей, які поєднані з технічним діагностуванням та неруйнівними методами контролю, а також з механікою руйнування і міцністю елементів конструкцій. 


\title{
ЕВРОИНТЕГРАЦИЯ И СОСТОЯНИЕ СТАНДАРТИЗАЦИИ В ОБЛАСТИ НЕРАЗРУШАЮШЕГО КОНТРОЛЯ В УКРАИНЕ
}

\author{
В. А. ТРОИЦКИЙ, Ю. Н. ПОСЫПАЙКО, С. А. ЩУПАК \\ ИЭС им. Е. О. Патона НАНУ. 03680, Киев-150, ул. Боженко, 11. Е-mail: office@paton.kiev.ua
}

\begin{abstract}
Рассмотрено состояние стандартизации в области неразрушающего контроля в период перехода Украины на международные стандарты. Описаны функции системы стандартизации и ее уровни, приведена информация о ходе гармонизации международных стандартов в Украине, основные изменения и новые подходы, установленные в Законе Украины «О стандартизации», который вступил в силу 3 января 2015 г.
\end{abstract}

Ключев ве е слов в : стандартизачия, неразрушающий контроль, евроинтегращия, гармонизаџия международных стандартов

Глобализация рынков производства и услуг требует унификации устанавливаемых к ним требований, и соблюдение этих требований является необходимым условием конкурентоспособности производимой и поставляемой на международный рынок продукции в широком понимании этого слова. Поэтому такое большое значение приобретает сегодня стандартизация - деятельность, направленная на разработку и определение требований, норм, правил и характеристик как обязательных к выполнению, так и рекомендованных. Причем стандартизация выполняет две функции: с одной стороны, дает возможность унифицировать требования к экспортируемой продукции (при этом влияние конкуренции положительно сказывается как на качестве этой продукции, так и на ее цене), а с другой, является инструментом защиты внутренних рынков и национальных производителей.

Первую функцию выполняет система международной стандартизации в лице Международной организации по стандартизации (ISO). Сфера деятельности ISO касается стандартизации во всех областях, кроме электротехники и электроники, которые относятся к компетенции Международной электротехнической комиссии (МЕК или IEC). Некоторые виды работ выполняются общими усилиями этих организаций. Например, вопрос информационных технологий, микропроцессорной техники и т.п. - это объекты общих разработок ISO/IEC.

Если рассматривать только данные по ISO/ TC 135 «Неразрушающий контроль», то в 20052014 гг. введено в действие 45 стандартов (24 из них за последние три года), еще 19 стандартов находятся на стадии проектов. При этом проблемами HK в ISO занимаются и другие комитеты, в частности, ISO/TC 44 «Сварка и родственные техноло-

(C) В.А. Троицкий, Ю.Н. Посыпайко, С.А. Щупак, 2015 гии», и таких комитетов в этой организации на сегодня 237.

Кроме того, влиятельным участником процесса стандартизации остается Европейский комитет по стандартизации (CEN). Хотя в настоящее время все больше европейских стандартов заменяются международными аналогами, все же их спектр остается достаточно большим.

Основной проблемой сегодня является значительное отставание национальных систем стандартизации в направлении гармонизации международных стандартов и введение их в качестве национальных.

В Украине на протяжении последних 15 лет принято более 80 новых стандартов в области НК. Большинство из них касается НК сварных соединений. 90 \% этих стандартов - гармонизированные в Украине европейские и международные стандарты. Курс на гармонизацию был установлен Законом Украины «О стандартизации» от 2001 г. и вступлением Украины во Всемирную торговую организацию (ВТО). Став членом ВТО, государство обязано выполнять положения договора о технических барьерах в торговле (ТБТ), а значит, отдавать предпочтение международным стандартам по сравнению с региональными и другими национальными стандартами.

Задачами стандартизации в Украине занимается Государственное предприятие «Украинский научно-исследовательский и учебный центр проблем стандартизации, сертификации и качества» (ГП «УкрНИУЦ»), которое было создано в 2003 г.

В составе центра работают Научно-исследовательский институт стандартизации, Институт управления качеством, Институт оценки соответствия, Институт подготовки специалистов в сфере управления качеством, стандартизации, оценки соответствия и метрологии и единый в Украине Главный фонд нормативных документов, который накапливает информационные ресурсы в 
сфере технического регулирования, обеспечивает их хранение, учет и доступ к ним пользователей. Предприятие имеет филиалы во Львове и Харькове.

ГП «УкрНИУЦ» является ведущей организацией Министерства экономического развития и торговли Украины в сфере стандартизации, сертификации и качества, которое формирует направления государственной политики в сфере стандартизации и сопредельных сферах.

Основные направления деятельности УкрНИУЦ:

- обеспечение функционирования и развития национальной системы стандартизации; разработка стандартов, экспертиза проектов стандартов, гармонизация национальных стандартов с международными и европейскими, координация деятельности национальных технических комитетов стандартизации (ТК);

- разработка систем управления качеством и окружающей средой и их мониторинг в Украине; предоставление консалтинговых услуг по внедрению систем управления качеством на производствах в целях повышения конкурентоспособности отечественных производителей; реализация Программы внедрения систем управления качеством в органах исполнительной власти;

- научно-методическая деятельность относительно обеспечения функционирования национальной системы сертификации;

- сертификация продукции, услуг и систем управления;

- подготовка и повышение квалификации специалистов в сфере стандартизации, сертификации, метрологии, управления качеством и экологического управления, защиты прав потребителей;

- ведение Главного фонда нормативных документов;

- подготовка и издание нормативных документов, пособий, каталогов нормативных документов, информационных указателей стандартов, указателей межгосударственных стандартов и т.п.

Согласно Закону Украины «О стандартизации» для разработки, рассмотрения и согласования проектов стандартов на общественных началах создаются ТК стандартизации. К работе в ТК привлекаются ведущие специалисты и полномочные представители заинтересованных организаций.

Вопросами гармонизации международных и европейских стандартов в области НК в Украине занимаются два технических комитета: ТК-78 «Техническая диагностика и неразрушающий контроль» и ТК-44 «Сварка и родственные процессы», секретариаты которых ведет Институт электросварки им. Е.О. Патона НАН Украины. Разработчиками гармонизированных стандартов, устанавливающих требования к НК, выступают и другие организации Украины, заинтересованные в принятии гармонизированных стандартов.

Однако слишком бюрократизированная система стандартизации приводит к тому, что на разработку и принятие одного стандарта уходит порой несколько лет. Были случаи, когда международные и европейские стандарты вступали в силу в качестве национальных уже после того, как они перестали быть актуальными. Выходом из этой ситуации может стать введение стандартов методом подтверждения («методом обложки»). Это означает, что стандарты будут вводиться в качестве национальных на языке оригинала, преимущественно, на английском языке. В декабре 2014 г. методом подтверждения в Украине было принято 22 гармонизированных европейских стандартов в области НК, которые вступают в действие с 1 января 2016 г. Ответственность за перевод и интерпретацию стандартов возлагается на их пользователей. И тут возможны проблемы, поскольку чаще всего специалисты НК владеют английским языком на уровне, недостаточном для свободного чтения документа в оригинале, а непрофессиональные переводы текстов могут стать причиной неправильного их толкования.

В области НК активную помощь в адаптации гармонизированных национальных стандартов путем экспертизы и редактирования их переводов может сыграть Украинское общество неразрушающего контроля и технической диагностики. Привлекая опытных специалистов и ученых, в тесном сотрудничестве с профильными техническими комитетами по стандартизации, общество имеет также возможность гармонизировать международные стандарты в качестве технических стандартов общества. Такую возможность предоставляет и новый Закон Украины «О стандартизации», принятый Верховной Радой Украины 5 июня 2014 г.

Закон предлагает создать новую национальную систему стандартизации, которая будет отвечать современным требованиям, в частности, принять организационные формы деятельности в сфере стандартизации согласно международной и европейской практике. Закон вступил в силу 3 января 2015 г.

Закон предусматривает создание и функционирование единого Национального органа стандартизации (НОC), функции которого были поручены ГП «УкрНИУЦ». Для обеспечения участия в управлении Национальным органом стандартизации Украины всем заинтересованным сторонам предусмотрено создание руководящего совета, являющегося согласовательно-надзорным органом НОС.

К полномочиям НОС относятся: организация и координация деятельности в сфере стандартизации, утверждение программы работ по стандартизации, принятие и отмена национальных стандар- 
тов, в том числе в сфере строительства, создание и прекращение деятельности технических комитетов стандартизации, представление интересов Украины в международной сфере региональных организаций.

Новая система стандартизации предусматривает введение двух уровней стандартизации в зависимости от субъекта стандартизации, принимающего стандарты: национальные стандарты, принятые НОС; и стандарты и технические условия, принятые предприятиями, учреждениями и организациями. При этом будет упразднена отраслевая стандартизация, в связи с чем в течение пятнадцати лет центральные органы исполнительной власти имеют право в соответствующих сферах деятельности и в рамках своих полномочий проверять, пересматривать свои отраслевые стандарты в целях перевода их на уровень национальных или на уровень стандартов предприятий либо их отмены.

Программой деятельности Кабинета министров Украины, утвержденной Постановлением Кабинета министров Украины № 695 от 09.12.2014 и одобренной Постановлением Вер- ховной Рады № 26-VIII от 11.12.2014, на 2015 г. определена цель - прекращение на территории Украины действия стандартов бывшего СССР.

Для достижения указанной цели национальный орган по стандартизации должен в текущем (2015 г.) отменить все действующие в Украине межгосударственные стандарты (ГОСТ), разработанные до 1992 г. В области НК в этот перечень попали более 50 стандартов. Все они будут пересмотрены и либо заменены соответствующими международными или европейскими, либо отменены без замены, если они морально устарели.

Широкое общественное обсуждение порядка введения и сути новых стандартов, бесспорно, послужит техническому прогрессу и повышению качества услуг в области НК.

1. Закон України «Про стандартизацію» від 05.06.2014 № 1315-VII.

2. Официальный сайт Министерства экономического развития и торговли Украины http://www.me.gov.ua/

3. Официальный сайт ГП «УкрНИУЦ» http://www.ukrndnc. org.ua/

4. Неразрушающий контроль в Украине: Справ. / Под ред. В.А. Троицкого и Ю.Н. Посыпайко. - Киев: ИЭС им. Е.О. Патона НАН Украины, 2012. - 144 с.

State of standartization in the field of nondestructive testing in the period of Ukraine's transition to international standards is described. Functions of standartization system and its levels are presented, and information on the course of harmonizing the international standards in Ukraine, main changes and new approaches specified in the Law of Ukraine "On Standardization" which came into force from January 3, 2015, is given.

Keywords : standardization, nondestructive testing, eurointegration, harmonizing of international standards

\section{МЕТОДЫ И ОБОРУДОВАНИЕ ДЛЯ НЕРАЗРУШАЮЩЕГО КОНТРОЛЯ СВАРНЫХ СОЕДИНЕНИЙ И МЕТАЛЛОКОНСТРУКЦИЙ}

Выявление поверхностных и подповерхностных дефектов производится капиллярным, тепловым, магнитопорошковым, вихретоковым и другими методами. Рентгеновская лаборатория института оснащена двумя высоковольтными рентгеновскими аппаратами (РАП-150/300 и «Экставольт-350») для радиографического и рентгенотелевизионного кон-

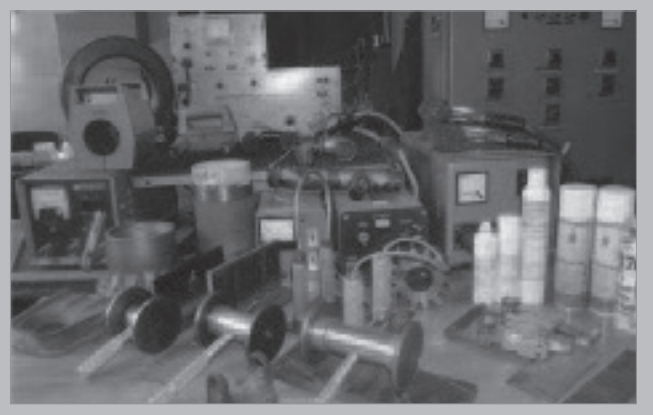
троля сварных и литых конструкций.

Герметичность сварных соединений и замкнутых объемов проверяют: газоаналитическим, манометрическим, пузырьковым, химическим и другими методами.

Обнаружение средствами компьютеризированного ультразвукового контроля коррозионных повреждений внутренних недоступных сторон трубопроводов, сосудов, реакторов, а также расслоений и массовых скоплений мелких несплошностей внутри металла.

\section{E-mail: office@paton.kiev.ua}




\section{IХ ВСЕУКРАИНСКИЙ ФЕСТИВАЛЬ НАУКИ}

19-21 мая 2015 г. состоялся IX Всеукраинский фестиваль науки, который впервые был проведен в 2007 г. Ежегодно Национальная академия наук Украины совместно с Министерством образования и науки Украины, Малой академией наук Украины, отраслевыми академиями наук Украины, Киевским национальным университетом им. Тараса Шевченко, Национальным техническим университетом Украины «КПИ» проводят ряд разнообразных по форме и содержанию и рассчитанных на разные категории участников мероприятия - дни открытых дверей, выступления ведущих отечественных и иностранных ученых с популярными лекциями, экскурсии в лаборатории и музеи, заседания круглых столов, презентации инновационных разработок, выставки, стендовые доклады, видеолектории, демонстрации научно-популярных фильмов и т.п.

Главной целью проведения Фестиваля науки является популяризация научных знаний в обществе, формирование позитивного отношения общественности к науке и привлечение талантливой молодежи к научной деятельности.

К организации и проведению Фестиваля постоянно привлекаются общественные организации и дипломатические представительства иностранных государств. В этом году уже традиционно главными партнерами были посольство Франции в Украине, Французский институт в Украине и Французский культурный центр. При их поддержке в рамках Фестиваля были проведены конференции, посвященные квантовой физике, научным реформам и охране окружающей среды, а также представлены серии документальных и мультипликационных фильмов.

Еще одним партнером нынешнего фестиваля стал фонд «Открытая политика», совместно с которым были проведены познавательные мастер-классы народных умельцев и зеленые лаборатории молодых ученых. Всего в рамках IX Bceукраинского фестиваля науки состоялось более 1000 мероприятий по всей Украине.

Торжественное открытие Фестиваля состоялось 19 мая 2015 г. в Институте электросварки им. Е.О. Патона НАН Украины. Открывая мероприятие, президент Национальной академии наук Украины академик Б.Е. Патон отметил, что Фестиваль с каждым годом приобретает все большую популярность, расширяет границы участников, сплачивает вокруг себя

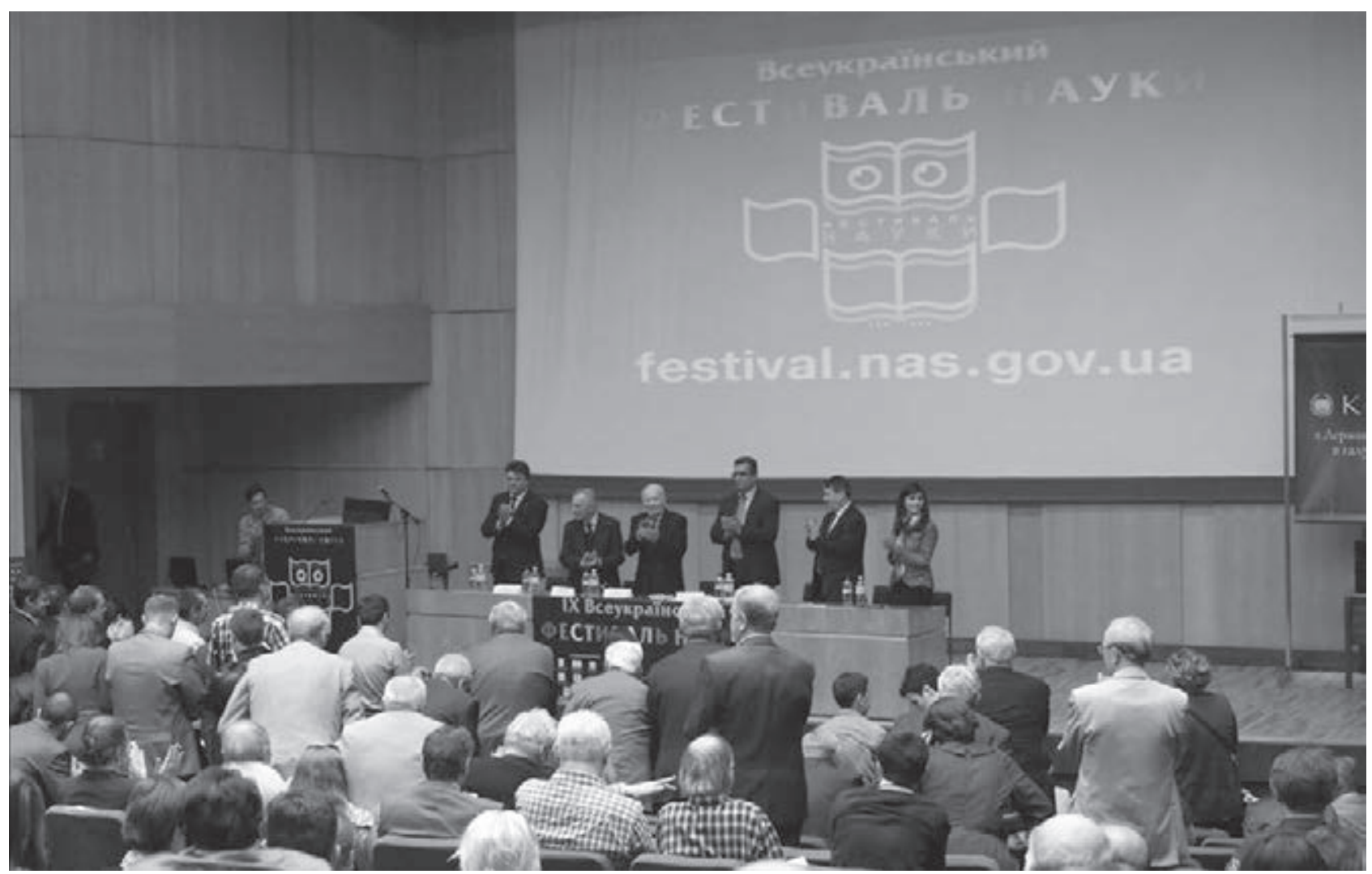

Слева направо: Министр молодежи и спорта Украины И.А. Жданов; первый вице-президент НАН Украины академик А.Г. Наумовец; Президент НАН Украины академик Б.Е. Патон; главный ученый секретарь НАН Украины академик В.Л. Богданов; посол Франции в Украине господин Ален Реми 


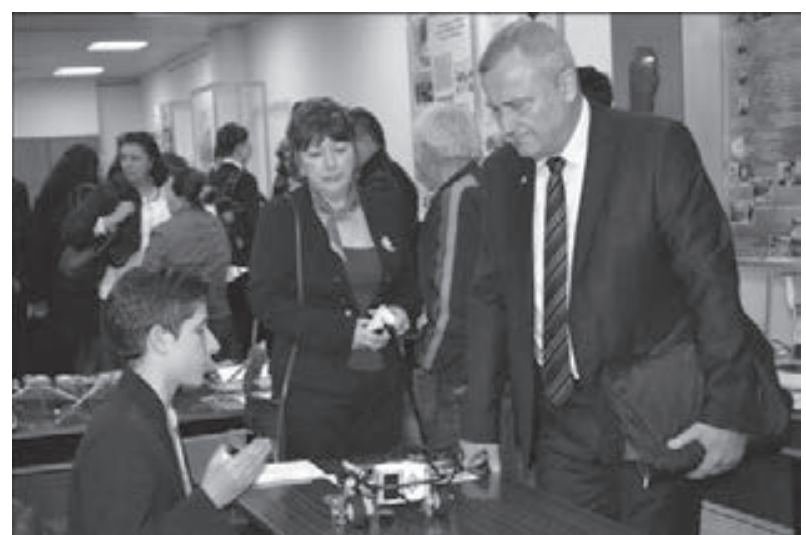

Вице-президент НАН Украины академик А.Г. Загородний знакомится с достижениями юных изобретателей

все больше заинтересованных лиц и успешное проведение Фестиваля в этом году станет, без сомнения, весомым вкладом в очень важное дело - популяризацию науки в нашей стране.

Сегодня перед отечественными учеными возникают ответственные задачи научного обеспечения экономического, социального и культурного развития Украины, ее надежной обороноспособности. Б.Е. Патон отметил, что именно наука должна стать локомотивом будущего нашего государства, его инновационного развития и процветания.

С приветствиями также выступили Министр молодежи и спорта Украины И.А. Жданов и посол Франции в Украине господин Ален Реми.

Открытие Фестиваля началось с научно-популярных лекций члена-корреспондента НАН Украины В.M. Сорокина, который рассказал о проблемах и перспективах светодиодного освещения, и И. Доценко - члена исследовательской группы, лауреата Нобелевской премии в области физики в 2012 г. Сержа Ароша на тему «Как приручить фотон?».

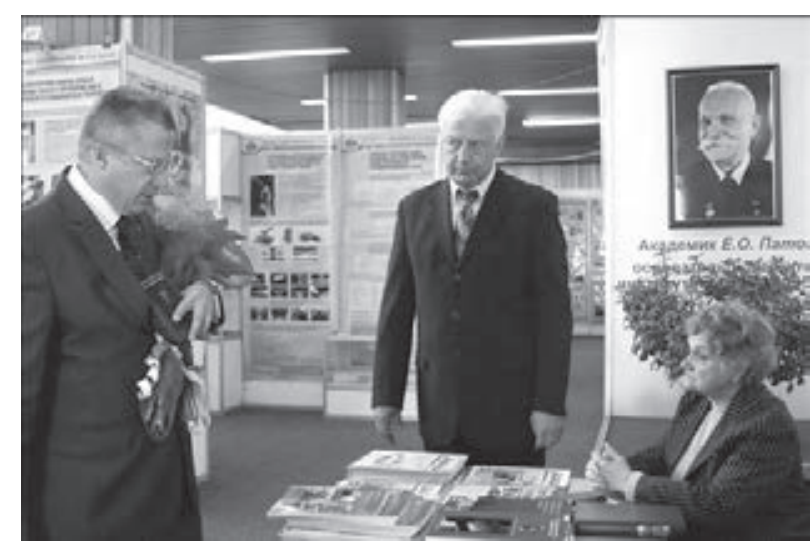

У стенда издательского дома «Патон»

В рамках Фестиваля действовала выставка-презентация научных разработок учреждений НАНУ. Около 50 организаций представили свои научные достижения в области здравоохранения, информационных технологий, машиностроения, жилищно-коммунального хозяйства, энергетики, сельского хозяйства, оборонной промышленности и т.д. Посетители имели возможность ознакомиться с конкурентоспособными научно-техническими разработками, которые уже внедрены или могут быть внедрены в производство для обеспечения замещения импортной продукции отечественной, не уступают зарубежным аналогам, или даже превышают их по основным качественным показателям.

Большое внимание посетителей мероприятия привлекла презентация научно-исследовательских работ учащихся Малой академии наук Украины и средних учебных учреждений г. Киева. Юные изобретатели представили свои приборы и технологии для использования в различных сферах общества.

По материалам пресс-службы НАН Украинь

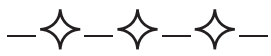

\section{КОНФЕРЕНЦИЯ-ВЫСТАВКА «НЕРАЗРУШАЮЩИЙ КОНТРОЛЬ 2015»}

Конференция-выставка «Неразрушающий контроль 2015» стала доброй традицией и в очередной раз собрала специалистов НК 12 и 13 мая в выставочном зале «Ассоциации ОКО».

Организатором Конференции «Неразрушающий контроль 2015» выступила «Ассоциация ОКО» при поддержке и содействии Украинского научно-исследовательского института неразрушающего контроля (УкрНИИНК), научно-производственных предприятий «ПРОМПРИЛАД» и
«УЛЬТРАКОН-СЕРВИС», Украинского общества неразрушающего контроля и технической диагностики (УОНКТД).

Гостями конференции стали: ГП «Укрзализныця»; ГП «Укрспецвагон», пгт. Панютино, Харьковская область; ГП «Дарницкий вагоноремонтный завод», г. Киев; ПАО «Кременчуцкий сталелитейный завод», г. Кременчуг; ГП «Стрийский вагоноремонтный завод», г. Стрий; ГП УДЦЗРП «Укррефтранс», г. Фастов; ОАО «Мариуполь- 
ский металлургический комбинат им. Ильича»; ГП «Государственный научно-исследовательский центр железнодорожного транспорта Украины», г. Киев; ПАО «Интерпайп НТЗ», г. Днепропетровск; АО «Сумский завод «Насосэнергомаш»; ГП «НПО «Павлоградский химический завод»; ЗАО «Международные Авиалинии Украины», г. Киев; ГП «Антонов», г. Киев; Институт электросварки им. Е.О. Патона НАН Украины, Киев; Рижский технический университет, Латвия; ООО «ТК «Спецмонтаж», Киев; ООО «Харьковский Профессиональный Колледж»; ООО «Приднепровский АЦНК и ТД», Днепропетровск; ГП «Государственный научно-исследовательский центр железнодорожного транспорта Украины», г. Киев; Национальный авиационный университет, г. Киев; ООО «Интрон-Сэт ЛТД», г. Донецк и другие компании и организации.

Программа конференции включала следующие направления:

- Разъяснение правил ПР НК В.1-В.5, действующих на пространстве 1520, утвержденных на пятьдесят седьмом заседании Совета по железнодорожному транспорту государств-участников содружества, 16-17 октября 2012 г., г. Ашхабад.

- Неразрушающий контроль как важный элемент обеспечения безопасности на железных дорогах.

- Семинар по обмену опытом между органами по сертификации персонала в области неразрушающего контроля, учебными и аттестационными центрами.

- Автоматизированный контроль в различных отраслях промышленности.

- Неразрушающие методы контроля в авиастроении и техническом обслуживании летательных аппаратов.

На открытии конференции «Неразрущающий контроль 2015» выступила с докладом председатель оргкомитета, заместитель директора ООО «ПРОМПРИЛАД» Луценко Т. М. С приветственным словом в адрес участников обратился председатель УОНКТД профессор Троицкий В.А.

Оновной темой первого дня конференции стали вопросы НК технических объектов железнодорожного транспорта. Учитывая важность надежной и бесперебойной работы железнодорожного транспорта, работа началась с обсуждения Правил ПР НК В.1-В.5.

Правила регламентируют общие требования к организации и применяемым видам (методам) НК, условия и порядок выполнения НК, а также устанавливают общие требования к технологической документации по НК, средствам НК и квалификации персонала. Были рассмотрены все пункты правил и даны разъяснения по ним.
Затем были заслушаны доклады специалистов НПФ «ПРОМПРИЛАД», «УЛЬТРАКОН-СЕРВИС» и УкрНИИНК, затрагивающие актуальные вопросы НК технических объектов железнодорожного транспорта и обеспечения безопасности на железных дорогах Украины.

На семинаре по обмену опытом между ррганами по сертификации персонала в области НК, учебными и Аттестационными центрами (руководитель семинара Радько В.И.), гости активно обсуждали выступления, обменивались мнениями по вопросам оптимизации систем определения квалификации персонала НК и рассматривали предложения по вопросам сотрудничества.

Во второй день конференции «Неразрушающий контроль 2015» большая часть докладов была посвящена автоматизированному контролю в различных отраслях промышленности. Предприятия «Ассоциации ОКО» обладают полноценной базой для разработки новых средств и технологий НК, методической документации и, соответственно, являются лидирующими отечественными производителями автоматизированных систем и установок неразрушающего контроля.

Завершали работу конференции специалисты научно-производственных фирм «УЛЬТРАКОН-СЕРВИС» и «ПРОМПРИЛАД» Черненко А.Н. и Опанасенко А.В. докладами о возможностях применения ультразвукового и вихретокового методов контроля в авиации. Обсуждались вопросы проведения ультразвукового контроля элементов конструкции самолетов Boeing 737-300, -400, 500 в условиях эксплуатации, применение универсального вихретокового дефектоскопа ВД3-81 при контроле дисков авиационных двигателей и эксплуатационный контроль узлов самолетов.

Во время проведения конференции работала выставка приборов и средств НК производства предприятий Ассоциации «ОКО», на которой можно было увидеть процесс контроля на представленных образцах и получить практические ответы по работе оборудования.

Программа конференции и общность интересов способствовали созданию комфортной обстановки для свободного и живого общения, обмена мнениями и поиском новых решений задач НК.

Майская конференция, в неизменной традиции которой насыщенная программа, содержательные доклады и интересные дискуссии, - это свидетельство того, что «Неразрушающий контроль 2015» является профессиональным событием в отрасли, которое отражает тенденции развития этого направления и ежегодно собирает ведущих специалистов НК. 
ПОДПИСКА - 2015

на журнал «Техническая диагностика и неразрушающий контроль»

\begin{tabular}{||c|c|c|c|c|c||}
\hline \multicolumn{2}{|c|}{ Украина } & \multicolumn{2}{c|}{ Россия } & \multicolumn{2}{c||}{ Страны дальнего зарубежья } \\
\hline на полугодие & на год & на полугодие & на год & на полугодие & на год \\
\hline 240 грн. & 480 грн. & 1800 руб. & 3600 руб. & 30 дол. США & 60 дол. США \\
\hline В стоимость подписки включена доставка заказной бандеролью. \\
\hline
\end{tabular}
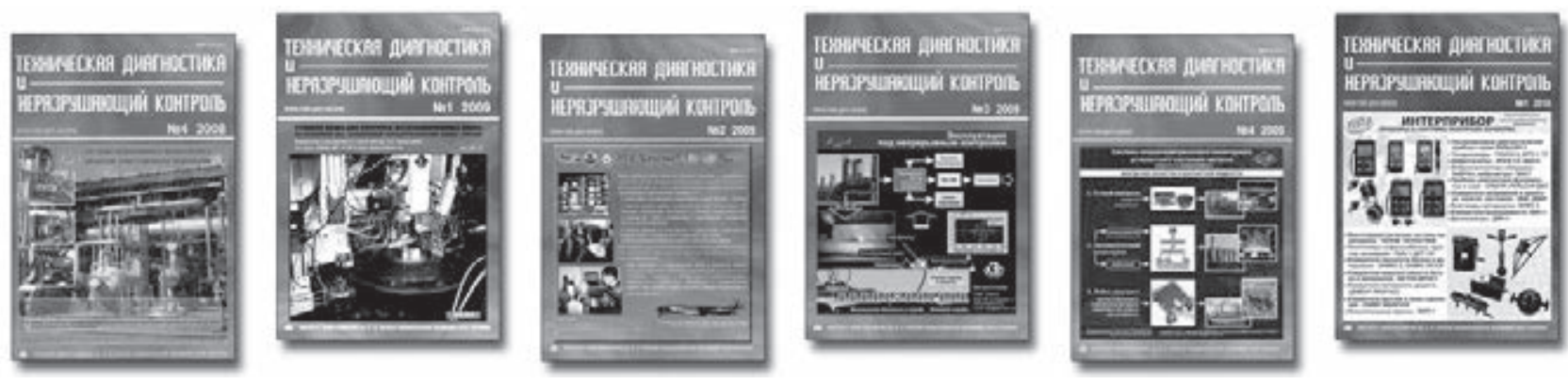

Подписку на журнал «Техническая диагностика и неразрушающий контроль» можно оформить непосредственно через редакцию или по каталогам подписных агентств «Пресса», "Идея», «Прессцентр», «Информнаука», «Блицинформ», «Меркурий» (Украина) и «Роспечать», «Пресса России» (Россия).

Подписка на электронную версию журнала

«Техническая диагностика и неразрушающий контроль»

на сайте: www.patonpublishinghouse.com.

Правила для авторов: www.patonpublishinghouse.com/rus/journals/tdnk/rules

Лицензионное соглашение: www.patonpublishinghouse.com/rus/journals/tdnk/license

В 2015 г. в открытом доступе архивы статей журнала за 2003-2013 гг.

\section{РЕКЛАМА в журнале «Техническая диагностика и неразрушающий контроль»}

Реклама публикуется на обложках и внутренних вклейках следующих размеров

- Первая страница обложки (190x190 мм)

- Вторая, третья и четвертая страницы обложки (200×290 мм)

- Первая, вторая,третья, четвертая страницы внутренней обложки (200×290 мм)

- Вклейка A4 (200×290 мм)

- Разворот A3 (400x290 мм)

- 0,5 A4 (185x130 мм)

- 0,25 A4 (90x130 мм)

- Размер журнала после обрези 200x290 мм
- В рекламных макетах, для текста, логотипов и других элементов необходимо отступать от края модуля на 5 мм с целью избежания потери части информации Все файлы в фрормате IBM PC

- Corell Draw, версия до 10.0

- Adobe Photoshop, версия до 7.0

- QuarkXPress, версия до 7.0

- Изображения в формате TIFF, цветовая модель СMYK, разрешение $300 \mathrm{dpi}$

\section{Стоимость рекламы и оплата}

- Цена договорная

- По вопросам стоимости размещения рекламы, свободной площади и сроков публикации просьба обращаться в редакцию
- Оплата в гривнях или рублях РФ по официальному курсу

- Для организаций-резидентов Украины цена с НДС и налогом на рекламу

- Для постоянных партнеров предусмотрена система скидок

- Стоимость публикации статьи на правах рекламы составляет половину стоимости рекламной площади

- Публикуется только профильная реклама (техническая диагностика и неразрушающий котроль)

- Ответственность за содержание рекламных материалов несет рекламодатель

\section{Контакты:}

Тел./факс: (38044) 205-23-90; 200-54-84

E-mail: journal@paton.kiev.ua www.patonpublishinghouse.com
Подписано к печати 16.06.2015. Формат 60×84/8. Офсетная печать.

Усл. печ. л. 9,04. Усл.-отт. 9,89. Уч.-изд. л. 10,24

Печать ООО «Фирма «Эссе».

03142, г. Киев, просп. Академика Вернадского, 34/1. 